NISTIR 7137

\title{
Simulation of the Dynamics of a Fire in the Basement of a Hardware Store - New York, June 17, 2001
}

Nelson Bryner Stephen Kerber 
NISTIR 7137

\title{
Simulation of the Dynamics of a Fire in the Basement of a Hardware Store - New York, June 17, 2001
}

\author{
Nelson Bryner \\ Stephen Kerber
}

Building and Fire Research Laboratory National Institute of Standards and Technology Gaithersburg, MD 20899-8661

May 2004

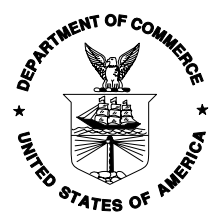

U.S. Department of Commerce Donald D. Evans, Secretary

Technology Administration Phillip J. Bond, Under Secretary for Technology

National Institute of Standards and Technology Arden L. Bement, Director 


\section{Table of Contents}

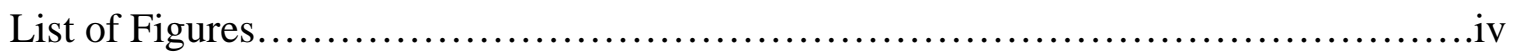

List of Tables.....................................................................

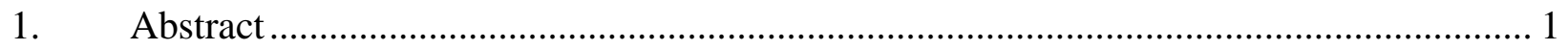

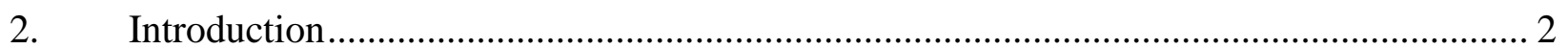

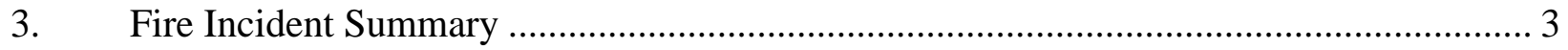

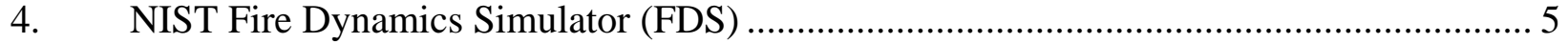

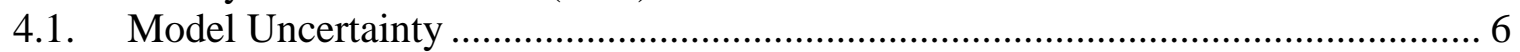

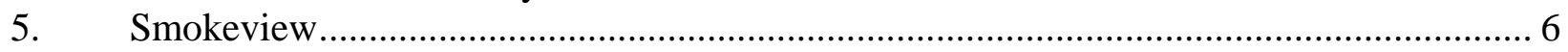

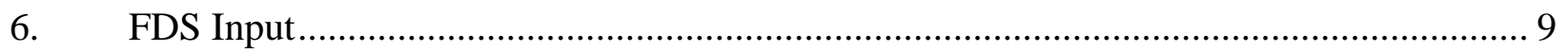

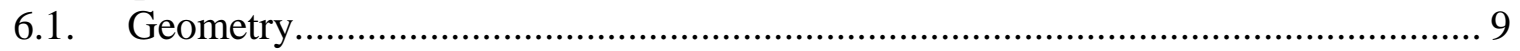

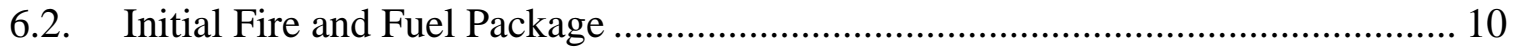

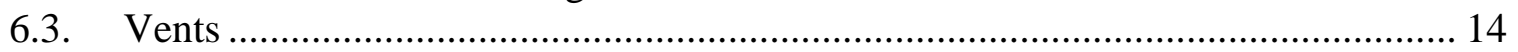

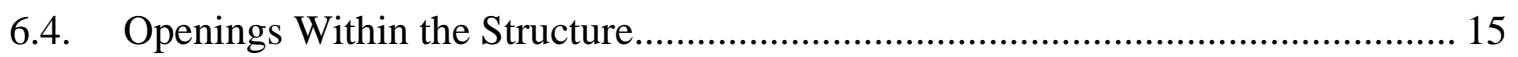

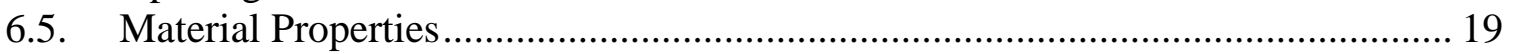

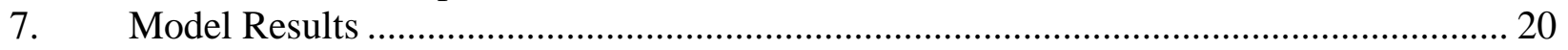

7.1. Model Geometry and Iso-Surfaces Output ................................................... 20

7.2. Fire Simulation -Temperature and Oxygen Concentration Predictions ................ 24

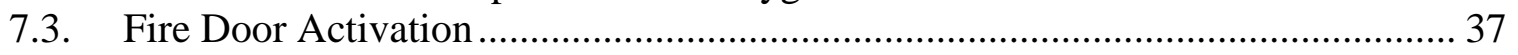

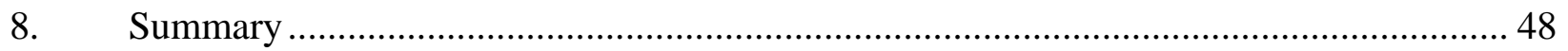

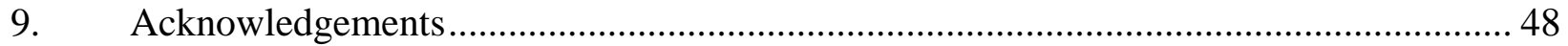

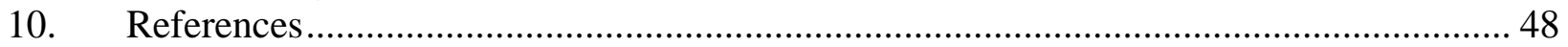




\section{List of Figures}

1. Plan View of Basement of Hardware Store..............................................

2. Plan View of Hardware Store Basement with Exposures Defined by Fire Department..................................................................

3a. Basement of Hardware Store Plan View with Dimensions (feet) .....................11

3b. Basement of Hardware Store Plan View with Dimensions (meters) ....................11

4. Merchandise and Shelving Not Included in Simulation ..............................12

5. Near the Simulated Fire Source the Simulation Used Smaller Cells ...................12

6. Remote From the Simulated Fire Source the Simulation Used Larger Cells.............13

7. FDS Model Adjusts Walls to Fit Computational Grid and Cells .....................13

8. Location of Paint, Solvents, and Propane in Basement of Hardware Store ............15

9. View Generated by Model Simulation Looking from Front of Unit 20 Towards

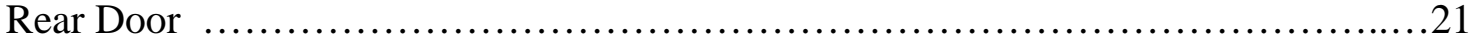

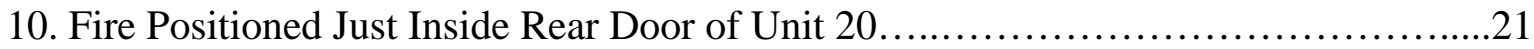

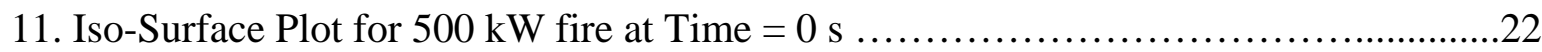

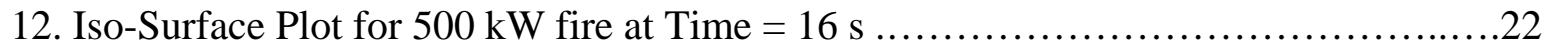

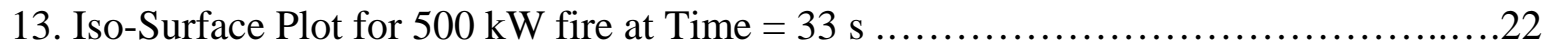

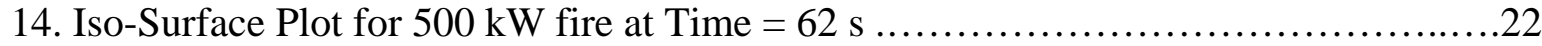

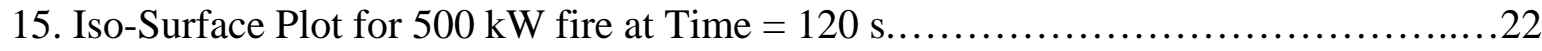

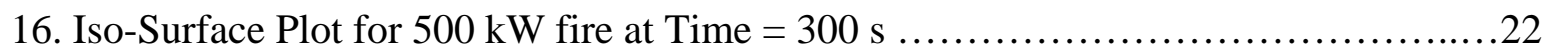

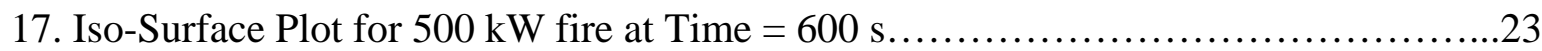

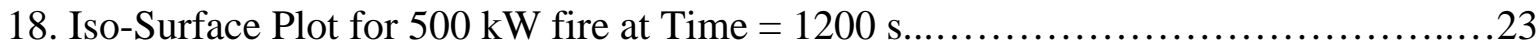

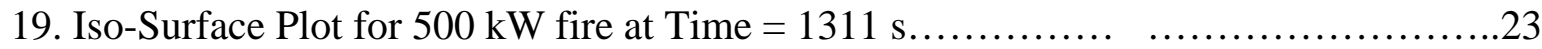

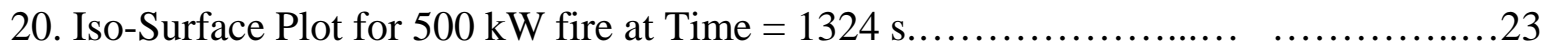

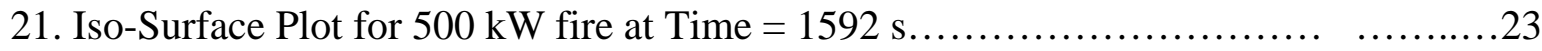

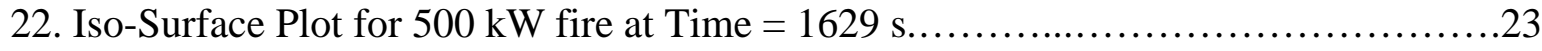

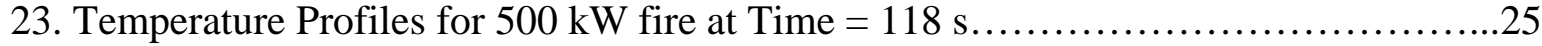

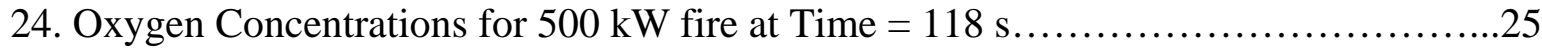

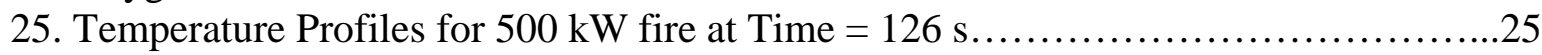

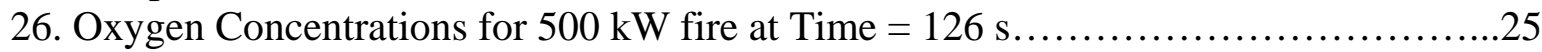

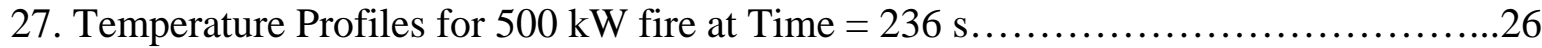

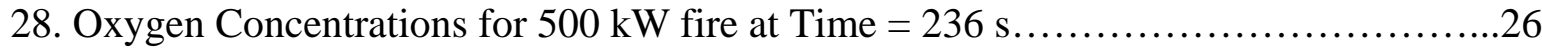

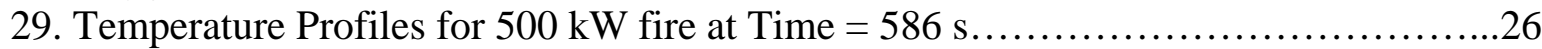

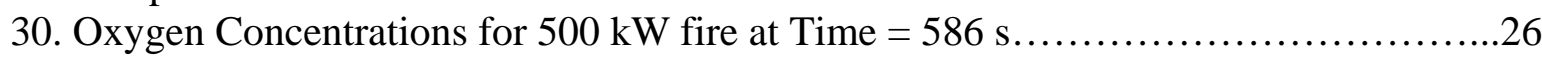

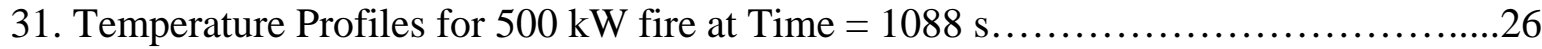

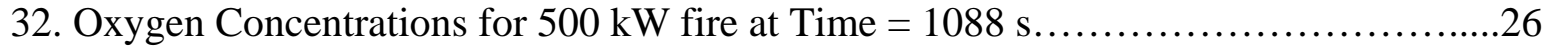

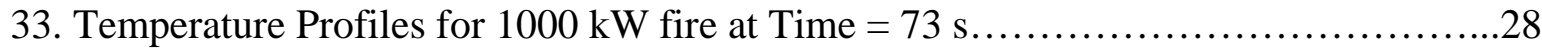

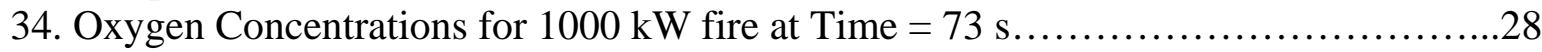

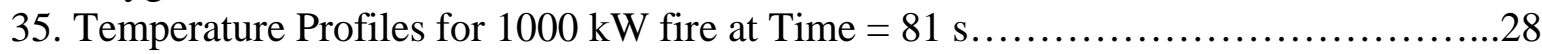

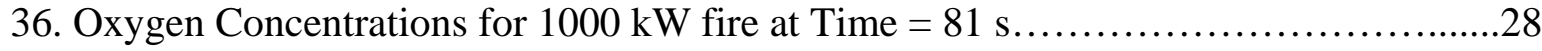

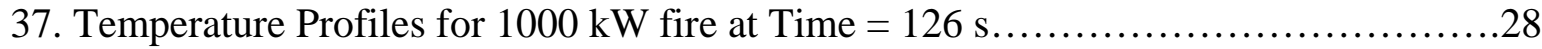

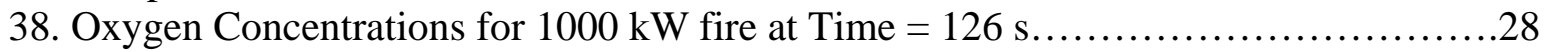




\section{List of Figures cont'd.}

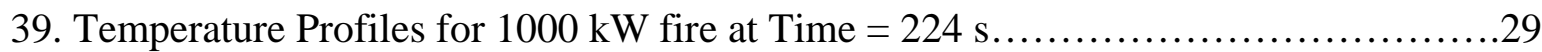

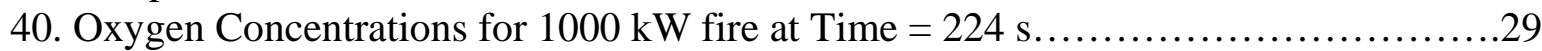

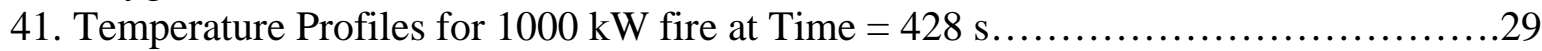

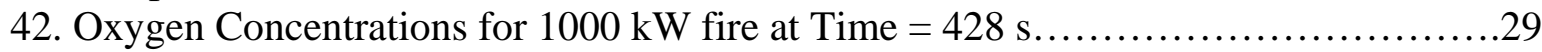

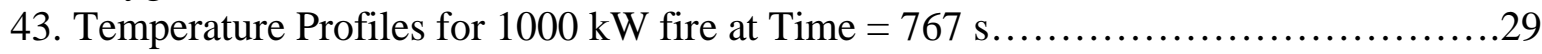

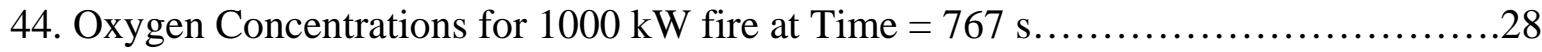

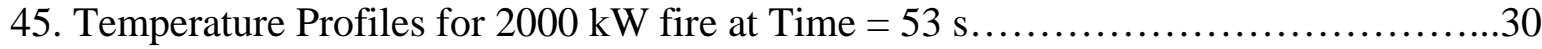

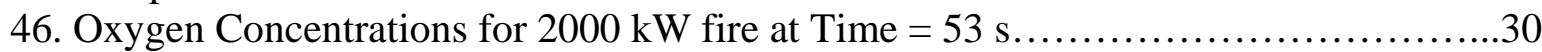

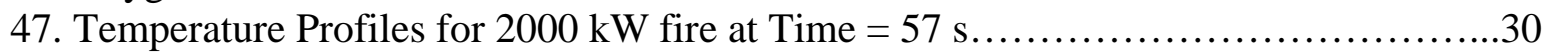

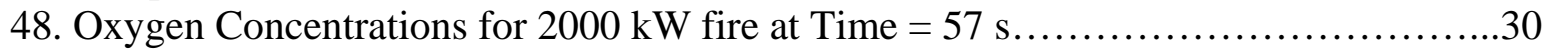

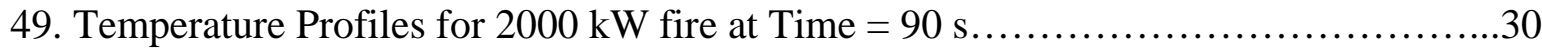

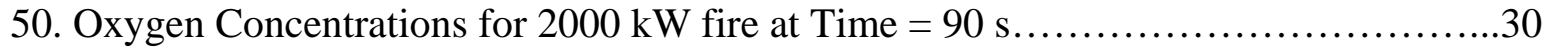

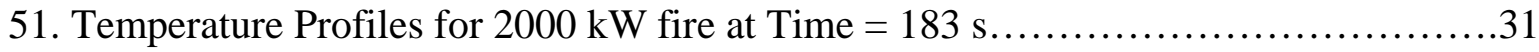

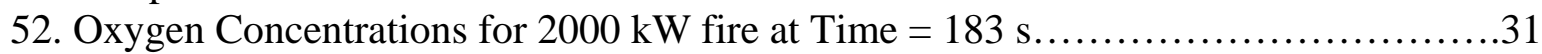

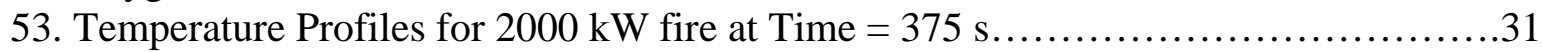

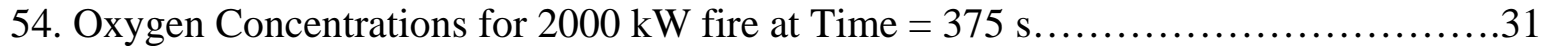

55. Temperature Profiles for $500 \mathrm{~kW}$ fire at Time $=120 \mathrm{~s}-$ Fire Door Open................33

56. Oxygen Concentrations for $500 \mathrm{~kW}$ fire at Time $=120 \mathrm{~s}-$ Fire Door Open..............33

57. Temperature Profiles for $500 \mathrm{~kW}$ fire at Time $=128 \mathrm{~s}-$ Fire Door Open................33

58. Oxygen Concentrations for $500 \mathrm{~kW}$ fire at Time $=128 \mathrm{~s}-$ Fire Door Open..............33

59. Temperature Profiles for $500 \mathrm{~kW}$ fire at Time $=235 \mathrm{~s}-$ Fire Door Open................33

60. Oxygen Concentrations for $500 \mathrm{~kW}$ fire at Time $=235 \mathrm{~s}-$ Fire Door Open.............33

61. Temperature Profiles for $500 \mathrm{~kW}$ fire at Time $=566 \mathrm{~s}-$ Fire Door Open................34

62. Oxygen Concentrations for $500 \mathrm{~kW}$ fire at Time $=566 \mathrm{~s}-$ Fire Door Open..............34

63. Temperature Profiles for $500 \mathrm{~kW}$ fire at Time $=1221 \mathrm{~s}-$ Fire Door Open...............34

64. Oxygen Concentrations for $500 \mathrm{~kW}$ fire at Time $=1221 \mathrm{~s}-$ Fire Door Open............34

65. Temperature Profiles for $1000 \mathrm{~kW}$ fire at Time $=74 \mathrm{~s}-$ Fire Door Open................34

66. Oxygen Concentrations for $1000 \mathrm{~kW}$ fire at Time $=74 \mathrm{~s}-$ Fire Door Open..............34

67. Temperature Profiles for $1000 \mathrm{~kW}$ fire at Time $=82 \mathrm{~s}-$ Fire Door Open................35

68. Oxygen Concentrations for $1000 \mathrm{~kW}$ fire at Time $=82 \mathrm{~s}-$ Fire Door Open..............35

69. Temperature Profiles for $1000 \mathrm{~kW}$ fire at Time $=128 \mathrm{~s}-$ Fire Door Open................35

70. Oxygen Concentrations for $1000 \mathrm{~kW}$ fire at Time $=128 \mathrm{~s}-$ Fire Door Open............35

71. Temperature Profiles for $1000 \mathrm{~kW}$ fire at Time $=223 \mathrm{~s}-$ Fire Door Open...............35

72. Oxygen Concentrations for $1000 \mathrm{~kW}$ fire at Time $=223 \mathrm{~s}-$ Fire Door Open............35

73. Temperature Profiles for $1000 \mathrm{~kW}$ fire at Time $=429 \mathrm{~s}-$ Fire Door Open...............36

74. Oxygen Concentrations for $1000 \mathrm{~kW}$ fire at Time $=429 \mathrm{~s}-$ Fire Door Open............36

75. Temperature Profiles for $1000 \mathrm{~kW}$ fire at Time $=788 \mathrm{~s}-$ Fire Door Open...............36

76. Oxygen Concentrations for $1000 \mathrm{~kW}$ fire at Time $=788 \mathrm{~s}-$ Fire Door Open............36

77. Temperature Profiles for $1000 \mathrm{~kW}$ fire at Time $=1270 \mathrm{~s}-$ Fire Door Open..............36

78. Oxygen Concentrations for $1000 \mathrm{~kW}$ fire at Time $=1270 \mathrm{~s}-$ Fire Door Open...........36

79. Temperature Profiles for $2000 \mathrm{~kW}$ fire at Time $=54 \mathrm{~s}-$ Fire Door Open................38

80. Oxygen Concentrations for $2000 \mathrm{~kW}$ fire at Time $=54 \mathrm{~s}-$ Fire Door Open..............38 


\section{List of Figures cont'd.}

81. Temperature Profiles for $2000 \mathrm{~kW}$ fire at Time $=58 \mathrm{~s}-$ Fire Door Open................38

82. Oxygen Concentrations for $2000 \mathrm{~kW}$ fire at Time $=58 \mathrm{~s}-$ Fire Door Open..............38

83. Temperature Profiles for $2000 \mathrm{~kW}$ fire at Time $=87 \mathrm{~s}-$ Fire Door Open................38

84. Oxygen Concentrations for $2000 \mathrm{~kW}$ fire at Time $=87 \mathrm{~s}-$ Fire Door Open..............38

85. Temperature Profiles for $2000 \mathrm{~kW}$ fire at Time $=166 \mathrm{~s}-$ Fire Door Open...............39

86. Oxygen Concentrations for $2000 \mathrm{~kW}$ fire at Time $=166 \mathrm{~s}-$ Fire Door Open............39

87. Temperature Profiles for $2000 \mathrm{~kW}$ fire at Time $=375 \mathrm{~s}-$ Fire Door Open...............39

88. Oxygen Concentrations for $2000 \mathrm{~kW}$ fire at Time $=375 \mathrm{~s}-$ Fire Door Open.............39

89. Temperature Profiles for $2000 \mathrm{~kW}$ fire at Time $=644 \mathrm{~s}-$ Fire Door Open...............39

90. Oxygen Concentrations for $2000 \mathrm{~kW}$ fire at Time $=644-$ Fire Door Open.............39

91. Temperatures (Centigrade) versus Time for Combustion Gases Near the Fusible Link On the Fire Door for a $500 \mathrm{~kW}$ Fire..............................................41

92. Temperatures (Fahrenheit) versus Time for Combustion Gases Near the Fusible Link On the Fire Door for a $500 \mathrm{~kW}$ Fire.............................................41

93. Temperatures (Centigrade) versus Time for Combustion Gases Near the Fusible Link On the Fire Door for a $500 \mathrm{~kW}$ Fire - Fire Door Open...............................42

94. Temperatures (Fahrenheit) versus Time for Combustion Gases Near the Fusible Link On the Fire Door for a $500 \mathrm{~kW}$ Fire - Fire Door Open.................................42

95. Temperatures (Centigrade) versus Time for Combustion Gases Near the Fusible Link On the Fire Door for a $1000 \mathrm{~kW}$ Fire..............................................43

96. Temperatures (Fahrenheit) versus Time for Combustion Gases Near the Fusible Link On the Fire Door for a $1000 \mathrm{~kW}$ Fire...........................................43

97. Temperatures (Centigrade) versus Time for Combustion Gases Near the Fusible Link On the Fire Door for a $1000 \mathrm{~kW}$ Fire - Fire Door Open.............................44

98. Temperatures (Fahrenheit) versus Time for Combustion Gases Near the Fusible Link On the Fire Door for a $1000 \mathrm{~kW}$ Fire - Fire Door Open.............................44

99. Temperatures (Centigrade) versus Time for Combustion Gases Near the Fusible Link On the Fire Door for a $2000 \mathrm{~kW}$ Fire...........................................45

100.Temperatures (Fahrenheit) versus Time for Combustion Gases Near the Fusible Link On

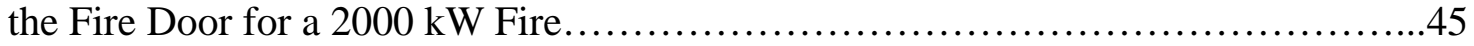

101.Temperatures (Centigrade) versus Time for Combustion Gases Near the Fusible Link On the Fire Door for a $2000 \mathrm{~kW}$ Fire - Fire Door Open............................46

102.Temperatures (Fahrenheit) versus Time for Combustion Gases Near the Fusible Link On the Fire Door for a $2000 \mathrm{~kW}$ Fire - Fire Door Open............................46 


\section{List of Tables}

1. Approximate Timeline of Events for Front of Hardware Store........................

2. Approximate Timeline of Events for Rear and Side of Hardware Store.................8

3. Total Heat Release for a Number of Fuels......................................16

4. Estimated Energy Content of Solvents in Basement of Hardware Store ................17

5. Estimated Heat Release Rate for Fraction of Solvent Consumed by Fire...............18

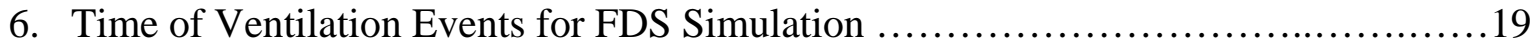

7. Thermal Properties Data........................................................ 


\section{Simulation of the Dynamics of a Fire in the Basement of a Hardware Store - New York, June 17, 2001}

\section{Abstract}

This report describes the results of computer model calculations to provide insight on the thermal conditions that may have occurred during a fire in a basement of a hardware store on June 17, 2001, in Queens, New York. These calculations were performed using the National Institute of Standards and Technology (NIST) Fire Dynamics Simulator (FDS).

A FDS model scenario was developed that represented the building geometry, material thermal properties, and fire behavior based on information and photographs either gathered at the fire scene or provided by the Fire Department of New York and the Bureau of Alcohol Tobacco and Firearms (ATF). The results from this model scenario are provided in this report.

The FDS (version 2.0) calculations that best represent the reported fire conditions indicate that a fire initially between $500 \mathrm{~kW}$ and $2000 \mathrm{~kW}$ originating near the rear basement door of the hardware store would have generated temperatures sufficient to cause the fusible link to release the fire door in less than $130 \mathrm{~s}$. The oxygen concentration profiles suggest that a $2000 \mathrm{~kW}$ fire with the fire door closed could have depleted the oxygen in Unit 20 in less than $380 \mathrm{~s}$. A $2000 \mathrm{~kW}$ fire with the fire door open would have required more time, approximately $650 \mathrm{~s}$, in order to deplete the oxygen in Unit 20 and 22. This limited set of fire reconstructions included $500 \mathrm{~kW}, 1000 \mathrm{~kW}$, and $2000 \mathrm{~kW}$ initiating fires in scenarios that allowed the fire door to close and in cases where the fire door remained open. This range of $500 \mathrm{~kW}$ to $2000 \mathrm{~kW}$ corresponds to approximately $4 \%$ to $18 \%$ of the organics solvents becoming involved in the fire.

Key Words: cfd models; fire dynamics; fire fatalities; fire fighters; fire investigations; fire models; fire simulations; 


\section{Introduction}

Part of the mission of the Building and Fire Research Laboratory (BFRL) at the National Institute of Standards and Technology (NIST) is to conduct basic and applied fire research, including fire investigations, for the purposes of understanding fundamental fire behavior and to reduce losses from fire.

On June 17, 2001 a fire and subsequent explosion in the basement of a two story hardware store and apartment building in New York claimed the lives of three firefighters. The hardware store occupied the first floor and basement of two adjacent units while the apartments were located on the second floor above the hardware store. The first floor of the hardware store was used as display and retail space while the basement served as merchandise storage and assembly/repair area. The fire ignited near the rear door in the basement of the first unit and spread through an open doorway into the basement of the second unit. Ignition of unburned combustion products and flammable vapors in the basement of the second unit resulted in an explosion that generated sufficient pressure to lift the floor of the retail space (on the first floor above the basement). The displacement of first floor "blew" a fire fighter into the basement from the first floor. The movement of the first floor also caused a two-story exterior brick wall to collapse on a number of fire fighters. The three fatalities were the fire fighter "blown" into the basement and two fire fighters under the collapsed brick wall.

The National Institute for Occupational Safety and Health (NIOSH) investigates all line-ofduty firefighter deaths and publishes reports on those investigations [1]. At the request of the Fire Department of New York (FDNY), NIST has examined the fire dynamics of this incident to supplement the FDNY investigation. NIST has performed computer simulations of the fire using the newly developed NIST Fire Dynamics Simulator (FDS) and Smokeview, ${ }^{*}$ a visualization tool, to provide insight on the fire development and thermal conditions that may have existed in the restaurant during the fire. NIST has previously used FDS to predict the fire growth in other multiple-fatality fires [2, 3, 4]. This report describes the inputs and the results of the NIST FDS (Version 2.0) calculations.

Three areas of interest that were requested by the FDNY to be reconstructed:

1. What were the conditions, including temperature and oxygen concentrations, in the basements of the two units as the fire spread?

2. How soon would a fire door between the two basements have closed?

3. How would different initial heat release rates (500 kW, $1 \mathrm{MW}$, and $2 \mathrm{MW}$ ) impact the conditions and fire spread in the basements of the two units?

\footnotetext{
* Certain commercial equipment, instruments, or materials are identified in this report in order to specify the experimental procedure adequately. Such identification is not intended to imply recommendation or endorsement by the National Institute of Standards and Technology, nor is it intended to imply that the materials or equipment identified are necessarily the best available for the purpose.
} 


\section{Fire Incident Summary}

The Fire Department of New York and the Bureau of Alcohol, Tobacco, and Firearms, provided this information to NIST on the construction of the hardware store and the events that took place during the fire. A summary of the events relevant to developing the FDS predictions of the fire follows.

On the afternoon of June 17, 2001, a fire ignited in the basement area of a hardware store. The hardware store occupied the first floor and basement of two adjacent units, 12-20 and 12-22, while the apartments were located on the second floor above the hardware store.

The first floor of the hardware store was used as display and retail space while the basement served as merchandise storage and repair/assembly area. Facing the front of the hardware store, unit 12-20 is on right and unit 12-22 is on the left. The fire started near the rear door in the basement of unit 12-20 (Figure 1).

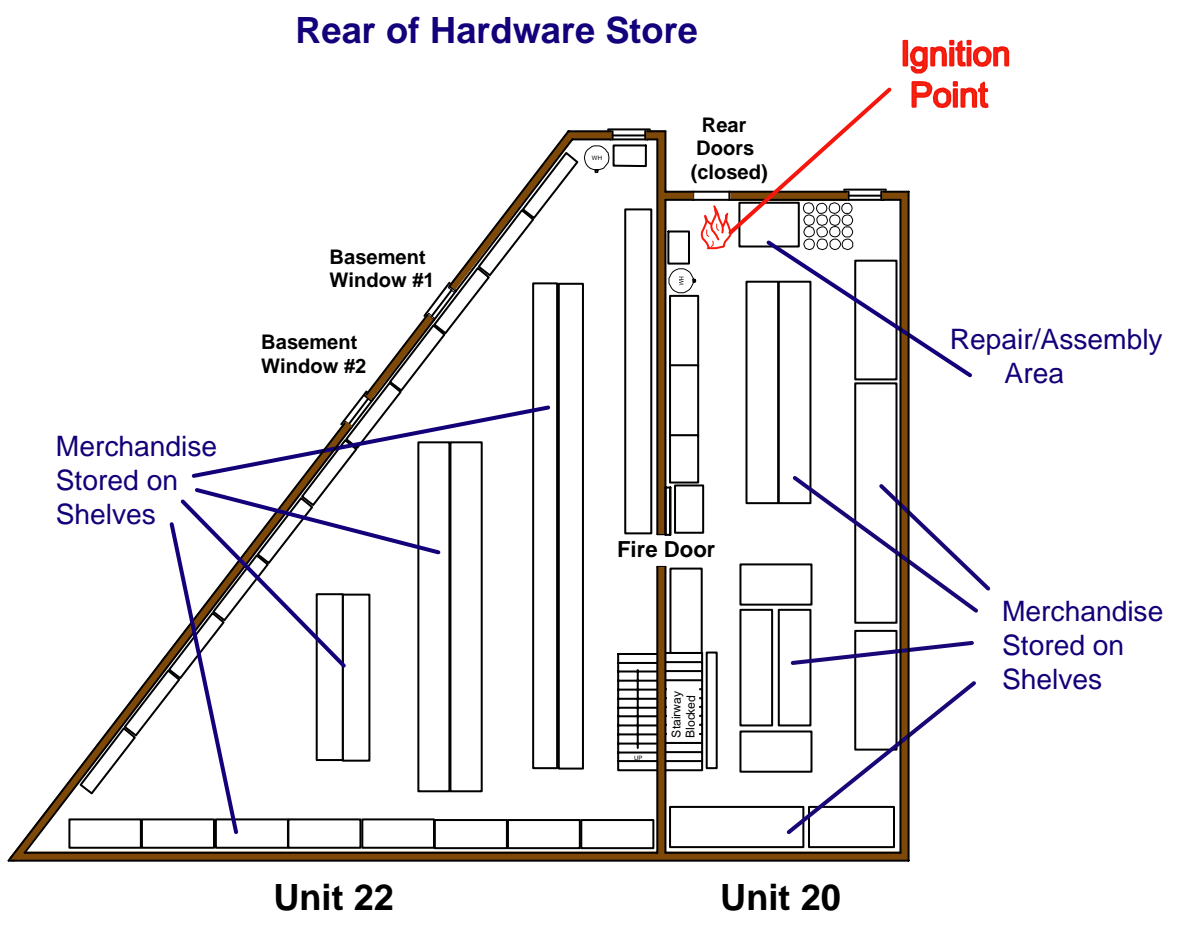

Front of Hardware Store

Figure 1. Plan View of the Basement of Hardware Store.

At 1420, the Queens Communication Office of the Fire Department of New York, received a telephone call reporting a fire in the hardware store in unit 12-20. A dispatcher assigned an engine company, a ladder company, and a battalion chief to the fire. At 1422, a squad company was returning from an earlier call and was driving down the block where the hardware store was located. A civilian flagged down the squad company and reported the fire. By 1427, at least four ladder companies, two engine companies, one squad company, 
and a battalion chief were on scene. The second story apartment windows were open, but no smoke was coming from the open windows. A ladder company officer chased occupants out of the apartments above the hardware store.

At 1426, forced entry was started on the roll-up doors on the front of the hardware store (exposure 1, see Figure 2). Two minutes later at 1428, forced entry of a roll-down gate was initiated to provide access to the rear yard of unit 12-20 (exposure 3). At the rear of the structure, after forcing the roll-down gate, the ladder company began forcible entry into the basement of 12-20 using a saw at 1432. The double set of steel security doors that were reinforced with steel bars proved extremely difficult to cut or remove. Entry was less difficult in the front where by 1432 the fire fighters had successfully entered the front of the store and located an interior stairway to the basement of unit 12-22. At 1433, ladder and squad companies inside the front of the store were instructed to hold the interior stairs, but not go down them because there was another hose line preparing to enter the basement through the rear door.

At 1435, the forcible entry team started to use a rabbit tool on the rear basement door. Members of a squad company and a ladder company joined up inside the front of the hardware store near the interior stairway to the basement. The interior stairway door was opened briefly and fire was observed. At the rear of the store at 1437, the use of the rabbit tool was not effective in forcing the rear door and the forcible entry team called for a Hurst

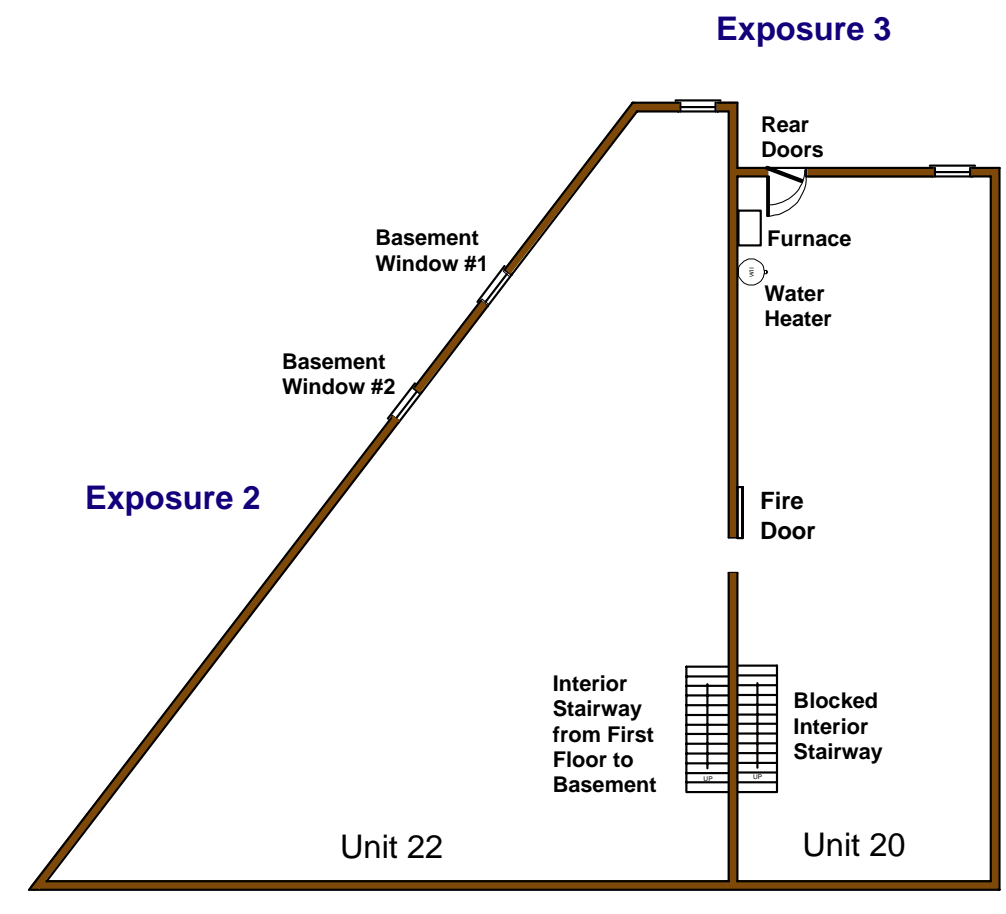

Exposure 1

Figure 2. Plan View of Hardware Store Basement with Exposures Defined by Fire Department. 
tool. At the front of the store, the interior team again opened the interior cellar door, discovered flames filling the entire door, and opened the nozzle to hit the flames. By 1440, smoke was observed coming from at least one of the two basement windows on exposure 2.

At 1441, the team inside the front of the store was advised that an interior attack down the stairways may be necessary due to difficulties in forcing the rear door. At 1442, the rear basement forcible entry team forced the right side of the door open approximately $0.46 \mathrm{~m}$ (18 inches). By 1445, a ladder company was cutting steel bars behind the rear basement door. A number of the fire fighters were working on forcing a second basement window on the exposed side. At 1446, the team inside the front of the store reported smelling organic vapors (varnish/lacquer/thinner smell). At 1448, an explosion occurred and the displacement of the first floor "blew" one fire fighter into the interior stairway near the front of the store (exposure 1) and also caused a brick wall to collapse on a number of fire fighters that were venting a basement window (exposure 2). Approximate timelines of events are given in Table 1 (front) and Table 2 (rear and side). Some of the events listed in Tables 1 and 2 were included to provide background information and not all the events were included in the computer simulation.

\section{4. $\quad$ NIST Fire Dynamics Simulator (FDS)}

NIST has developed a computational fluid dynamics (CFD) fire model using large eddy simulation (LES) techniques [5]. This model, called the NIST Fire Dynamics Simulator (FDS), has been demonstrated to predict the thermal conditions resulting from a compartment fire [6,7]. A CFD model requires that the room or building of interest be divided into small three-dimensional rectangular control volumes or computational cells. The CFD model computes the density, velocity, temperature, pressure and species concentration of the gas in each cell. Based on the laws of conservation of mass, momentum, species, and energy the model tracks the generation and movement of fire gases. FDS utilizes material properties of the furnishings, walls, floors, and ceilings to compute fire growth and spread. A complete description of the FDS model is given in reference [5].

For each time step and in each of the computational cells, FDS calculates the gas temperature, and concentration of various gases, including oxygen, carbon dioxide, and fuel. In order for the gaseous contents of a cell to burn or combust within a cell, there must be sufficient fuel and oxygen and the gas temperature must be above a specific temperature. For example, if the oxygen concentration drops below $15 \%$ and the gas temperature is less than $300{ }^{\circ} \mathrm{C}\left(570{ }^{\circ} \mathrm{F}\right)$, combustion is not allowed to take place. FDS does allow some additional burning with lower oxygen concentrations at higher temperatures. The complete oxygen/temperature phase space in which combustion is allowed and not allowed to take place is presented and discussed in the Technical Reference Guide for FDS [5]. Each cell which meets these requirements (fuel, oxygen, and temperature) is allowed to combust for that time step. If the conditions are not met, then that cell is not allowed to burn during that time step. 


\subsection{Model Uncertainty}

FDS can provide valuable insight into how a fire may have developed. However the model is only a simulation. The model output is dependent on a variety of input values such as material properties, time lines, geometry, and ventilation openings. Since complete knowledge of every detail of the fire site, fuel load or fire timeline is never availableestimations are incorporated into the model. For example, the estimation of the energy release rate of an initial "source fire" as a starting point for fire development and spread throughout the structure is a necessary part of re-creating this fire scenario. These estimations and others used in this simulation are further described in Section 6 of this report. These simulations assume a specific fire size and do not consider the origin or cause of the fire. These fire reconstructions only model the thermal conditions and oxygen concentrations during the fire growth and spread up to $1620 \mathrm{~s}$ into the event. FDS is not capable of modeling an explosion.

The ability of the FDS model to predict accurately the temperature and velocity of fire gases has been previously evaluated by conducting experiments, both lab-scale and fullscale, and measuring quantities of interest. If an excess of fuel is present or insufficient oxygen is available, a fire may be termed as fuel-rich or under-ventilated. If an excess of oxygen is present, a fire may be described as fuel-lean or over-ventilated. FDS can predict over-ventilated fire conditions better than under-ventilated conditions because underventilated fires require FDS to use an oxygen/temperature relationship to determine when combustion is not allowed to occur. For relatively simple fire driven flows, such as buoyant plumes and flows through doorways, FDS predictions are within the experimental uncertainty of the values measured in the experiments [6]. For example, if a gas flow velocity is measured at $0.5 \mathrm{~m} / \mathrm{s}(1.6 \mathrm{ft} / \mathrm{s})$ with an experimental uncertainty of $\pm 0.05 \mathrm{~m} / \mathrm{s}$ $( \pm 0.2 \mathrm{ft} / \mathrm{s})$, the FDS model gas flow velocity predictions were also in the range between $0.45 \mathrm{~m} / \mathrm{s}$ and $0.55 \mathrm{~m} / \mathrm{s}(1.5 \mathrm{ft} / \mathrm{s}$ and $1.8 \mathrm{ft} / \mathrm{s})$.

In large scale fire tests reported in [7], FDS temperature predictions were found to be within $15 \%$ of the measured temperatures and the FDS heat release rates were predicted to within $20 \%$ of the measured values. Therefore the results are presented as ranges to address these uncertainties.

\section{Smokeview}

Smokeview is a scientific visualization program that was developed to display the results of a FDS model computation. Smokeview produces animations or snapshots of FDS results [8]. A new feature of Smokeview allows the viewing of FDS output in 3dimensional animations. An iso-surface is a three dimensional version of a contour elevation often found on topographic maps. For this study, Smokeview determined which computational cells met all the requirements for combustion and displayed them as an orange/yellow surface. This orange/yellow surface provides a visual simulation of the flame surface. The fire source, $500 \mathrm{~kW}, 1000 \mathrm{~kW}$, or $2000 \mathrm{~kW}$, appears as an inverted conical surface. As additional cells meet the requirements for sustaining combustion, the orange/yellow surfaces spread across the upper portion of the room. As the fire consumes 
Table 1. Approximate Timeline of Events for Front of Hardware Store.

\begin{tabular}{|c|c|c|c|}
\hline Time & $\begin{array}{l}\text { FDS } \\
S\end{array}$ & $\operatorname{ime}$ & $\begin{array}{c}\text { Front of Store } \\
\text { Exposure } 1\end{array}$ \\
\hline 1420:52 & 0 & 0 & Report of fire \\
\hline 1422:48 & 56 & 1 & Squad unit drives by fire \\
\hline $\begin{array}{l}1425: 21 \\
1425: 49\end{array}$ & $\begin{array}{l}269 \\
297\end{array}$ & $\begin{array}{l}4 \\
5\end{array}$ & \\
\hline 1426 & 308 & 5 & Squad unit begins cutting roll-up gates at front of store \\
\hline 1430 & 548 & & Team removes roll-up gates for store front \\
\hline 1431 & 612 & & \\
\hline 1432 & 672 & 11 & \\
\hline 1433 & 732 & 12 & $\begin{array}{l}\text { Team reports fire in cellar near rear door. } \\
\text { Battalion Chief tells team that another line in rear and hold the stairs, do not go down }\end{array}$ \\
\hline 1433:45 & 777 & 13 & Team enters store and goes to rear wall...found inside cellar door \\
\hline 1434:03 & 795 & & $\begin{array}{l}\text { Battalion Chief orders two teams to hold interior stairway, but not to go down pending } \\
\text { rear attack }\end{array}$ \\
\hline 1435 & 852 & 14 & $\begin{array}{l}\text { Interior cellar door opened and fire is behind it. Light gray smoke, light blue flame fills } \\
\text { lower half of door }\end{array}$ \\
\hline 1437 & 972 & 16 & $\begin{array}{l}\text { Team opens nozzle to hit flames in inside cellar door, flames fill entire inside cellar } \\
\text { door }\end{array}$ \\
\hline 1439 & 1092 & 18 & \\
\hline 1442:38 & 1310 & & \\
\hline 1443 & 1332 & 22 & \\
\hline 1444 & 1392 & 23 & Team prepares to go down interior stairs to cellar \\
\hline 1446 & 1512 & 25 & Report of varnish/lacquer/thinner smell \\
\hline 1447:50 & 1622 & 27 & Explosion occurs. Firefighter "blown" into cellar. \\
\hline
\end{tabular}


Table 2. Approximate Timeline of Events for Rear and Side of Hardware Store.

\begin{tabular}{|c|c|c|c|c|}
\hline Time & $\begin{array}{c}\text { FDS } \\
S\end{array}$ & ime & $\begin{array}{c}\text { Rear of Store } \\
\text { Exposure } 3\end{array}$ & $\begin{array}{l}\text { Side of Store } \\
\text { Exposure } 2\end{array}$ \\
\hline $1420: 52$ & 0 & 0 & & \\
\hline $1422: 48$ & 56 & 1 & & \\
\hline $\begin{array}{l}1425: 21 \\
1425: 49\end{array}$ & $\begin{array}{l}269 \\
297\end{array}$ & $\begin{array}{l}4 \\
5\end{array}$ & $\begin{array}{l}\text { First engine unit arrives. } \\
\text { Second engine unit arrives }\end{array}$ & \\
\hline 1426 & 308 & 5 & & \\
\hline 1430 & 548 & & & \\
\hline 1431 & 612 & & Team starts to force rear cellar door & \\
\hline 1432 & 672 & 11 & $\begin{array}{l}\text { Third unit uses saw on rear door to cellar. Light } \\
\text { smoke from first floor windows }\end{array}$ & \\
\hline 1433 & 732 & 12 & & \\
\hline 1433:45 & 777 & 13 & & \\
\hline 1434:03 & 795 & & & \\
\hline 1435 & 852 & 14 & Forcible entry team use rabbit tool & \\
\hline 1437 & 972 & 16 & $\begin{array}{l}\text { Forcible entry team indicates rabbit tool not } \\
\text { effective }\end{array}$ & \\
\hline 1439 & 1092 & 18 & Hurst tool to rear cellar door & $\begin{array}{l}\text { FF starts to take rear window on } \\
\text { exp. } 2\end{array}$ \\
\hline 1442:38 & 1310 & & $\begin{array}{l}\text { Entry team forces right side of rear door open } \\
18 \text { " wide }\end{array}$ & \\
\hline 1443 & 1332 & 22 & $\begin{array}{l}\text { Team forces rear door. Door partially open, still } \\
\text { partially blocked. }\end{array}$ & $\begin{array}{l}\text { Preparing to force second basement } \\
\text { window }\end{array}$ \\
\hline 1444 & 1392 & 23 & & \\
\hline 1446 & 1512 & 25 & & \\
\hline 1447:50 & 1622 & 27 & Explosion occurs & $\begin{array}{l}\text { Explosion occurs. Brick wall } \\
\text { collapses on firefighters. }\end{array}$ \\
\hline
\end{tabular}


the oxygen within the room and fewer computational cells meet the combustion requirements, the flame surface appears to retreat or recede. In this report, Smokeview was used to generate animated iso-surfaces to visualize the movement and spread of the fire within the basement space.

\section{6. $\quad$ FDS Input}

Inputs required by FDS include the geometry of the structure, the computational cell size, the location of the ignition source, the energy release of the ignition source, thermal properties of walls, ceilings, floors, furnishings, and the size, location, and timing of door and window openings to the outside which critically influence fire growth and spread. The timings of the door and window openings used in the simulation are given in Table 2 . The timings of these events are based on the approximate timeline of the fire events from Table 1. These are based on information obtained from Fire Department of New York. The size and location of ventilation openings are based on architectural drawings and field measurements by Bureau of Alcohol, Tobacco, and Firearms, Fire Department of New York, and NIST.

\subsection{Geometry}

The basement floor plan of units 20 and 22 are shown in Figure 3a and 3b. Unit 20 was rectangular in shape with dimensions of approximately $17 \mathrm{~m}$ x $6 \mathrm{~m}$ (55 ft x $20 \mathrm{ft}$ ). Unit 22 was approximately triangular in shape with dimensions of $18.3 \mathrm{~m}$ (wall shared with Unit 20) x $15.8 \mathrm{~m}$ (60 ft x $52 \mathrm{ft})$ and a third side of $22.9 \mathrm{~m}$ (75 ft). Floor areas for Unit 20 and 22 were approximately $100 \mathrm{~m}^{2}$ and $167 \mathrm{~m}^{2}\left(1,100 \mathrm{ft}^{2}\right.$ and $\left.1,800 \mathrm{ft}^{2}\right)$, respectively. The combined floor area for the basement of the hardware store was approximately $270 \mathrm{~m}^{2}$ $\left(2,900 \mathrm{ft}^{2}\right)$. The bottom of the first floor joists were $2.3 \mathrm{~m}$ (92 inches) above the concrete floor. The volume of Unit 20 and 22 were $240 \mathrm{~m}^{3}\left(8450 \mathrm{ft}^{3}\right)$ and $390 \mathrm{~m}^{3}\left(13,800 \mathrm{ft}^{3}\right)$, respectively. The combined volume for the basement of the hardware store was approximately $630 \mathrm{~m}^{3}\left(22,250 \mathrm{ft}^{3}\right)$.

For computational purposes the hardware store basement was enclosed within a $35.0 \mathrm{~m} \mathrm{x}$ $13.5 \mathrm{~m} \times 5.0 \mathrm{~m}$ (114.8 ft x $44.3 \mathrm{ft} \times 16.4 \mathrm{ft})$ rectangular volume. For the FDS simulation this volume was divided into 734,000 computational cells. The focus of the simulation was the spread of the fire from its ignition point and the closure of the fire door. The merchandise and shelving were not included in the simulation geometry (Figure 4). The computational cells ranged from $125 \mathrm{~mm}$ x $255 \mathrm{~mm}$ x $125 \mathrm{~mm}$ (5.0 in x 10.0 in x 5.0 in) to $64 \mathrm{~mm} \times 255 \mathrm{~mm} \times 125 \mathrm{~mm}$ (2.5 in x 10.0 in x 5.0 in). The cells were smallest near the ignition point (Figures 5) and slightly larger in the rest of Unit 20 (Figures 6). The largest cells were used to simulate the volume in Unit 22. The size and location of the walls, doorways, and windows are adjusted by FDS to correspond to the nearest computational cell location (Figure 7). The result is walls and ceilings, used in the model, that appear thicker than they are in the actual structure. 


\subsection{Initial Fire and Fuel Package}

The fire started near the rear door in the basement of Unit 20 (Figure 1). The area near the rear door apparently served as a combination shipping/receiving and repair/assembly area for the hardware store. It is not clear what item or items ignited first. Packing material including used cardboard boxes, wrapping paper, and shipping boxes, may have been stacked near the rear door in preparation for disposal. Or, recently delivered merchandise or new retail stock may have been located near the rear door prior to restock of the merchandise on the first floor retail space. The heat release of several representative fuels, including trash bags, wood pallets, newspapers, and cartons, are tabulated in Table 3.

After items near the rear door ignited, the fire spread to other merchandise in the basement of Unit 20. At least 200 gallons of organic solvents, including acetone, alcohol, naphtha and paint thinner were stored near the rear of the basement of Unit 20. Most of the solvents were packaged in one gallon containers, although some of the solvents were stored in five gallon cans. In addition, up to 300 cans of spray paint (360 g or $12 \mathrm{oz}$.) were located along the common wall between Unit 20 and 22. The energy content of the solvents, propane cylinders, and spray paint was estimated in Table 4. Post-fire examination of the basements of Unit 20 demonstrated that a number of spray paint cans and many of the one gallon (3.78 l) solvent containers had been consumed during the fire. Post-fire inspection indicated that most of the one gallon (3.78 l) paint cans stacked near the rear door of Unit 20 and additional one gallon cans near the front of Unit 22 were not consumed by the fire. The propane cylinders ( $420 \mathrm{~g}$ or $14 \mathrm{oz}$.) that were removed post-fire from the lower shelves in the second row of shelves in Unit 22 were intact and had not burst or been consumed by the fire. Those intact propane cylinders appeared to represent a majority of the propane cylinders that were inventoried during the post-fire inspection.

The total heat released during a fire depends on type and quantity of fuels that were consumed by the fire. The total heat release rate for different fractions of solvent consumed by the fire is estimated in Table 5. If only $1 \%$ of the available organic solvents had been consumed by the fire over a period of 30 minutes, then the estimated heat release rate was $130 \mathrm{~kW}$. If $30 \%$ of the available solvents had been consumed over the same 30 minutes then the estimated heat release rate was $3900 \mathrm{~kW}$. It is not clear what percentage of the organic solvents and the contents of the spray paint cans were consumed by the fire.

These estimates do not include the propane cylinders that were located in Unit 22 and appeared to have survived the fire intact. Other merchandise would certainly have also contributed to the total heat release but are not included in these estimates, so these heat release rates are conservative.

Since the fire model does not have a mechanism to ignite liquid fuel in cans, it is necessary to provide the model with a realistic heat release rate and an area in which the heat is released by the burning fuel. A fire consuming approximately $4 \%, 9 \%$, and $18 \%$ of the organic solvents and paint would yield total heat release rates of $520 \mathrm{~kW}, 1010 \mathrm{~kW}$, and $2020 \mathrm{~kW}$, respectively (Table 5). Fires with $500 \mathrm{~kW}, 1000 \mathrm{~kW}$, and $2000 \mathrm{~kW}$ initial heat release rates were selected for the model simulation. Selecting smaller heat release rates could cause the gas temperatures in the upper layer to develop more slowly while choosing 

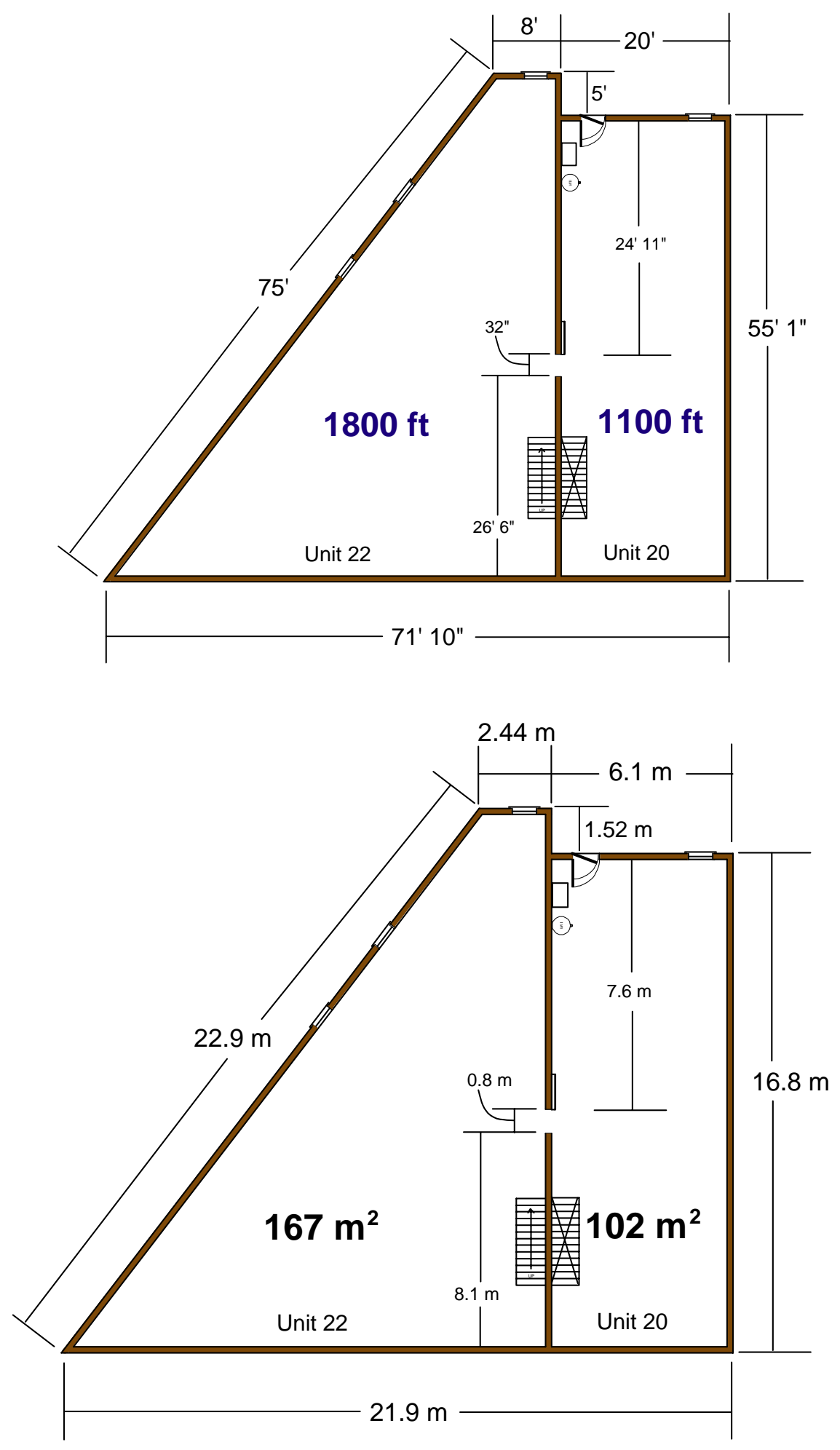

Figures 3a and 3b. Basement of Hardware Store Plan View with Dimensions (3a - English Units-upper diagram \& 3b - Metric Units-lower diagram). 


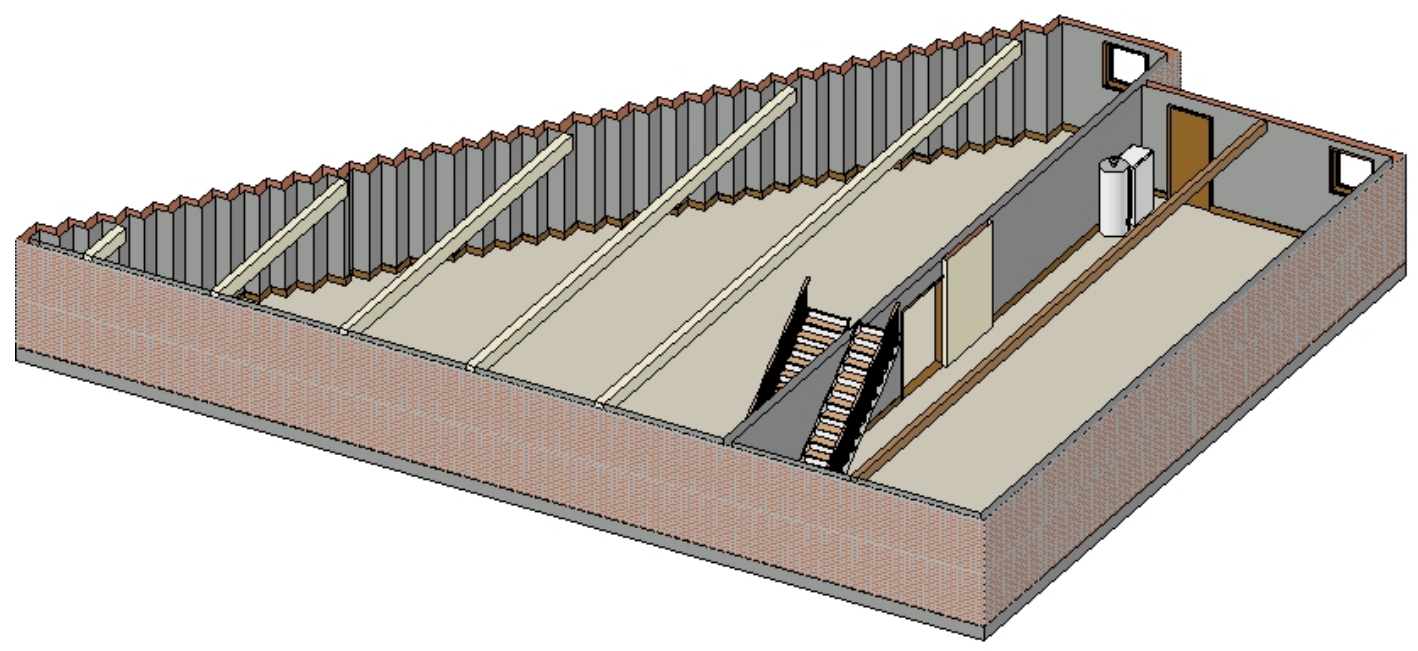

Figure 4. Merchandise and Shelving Not Included in Simulation.

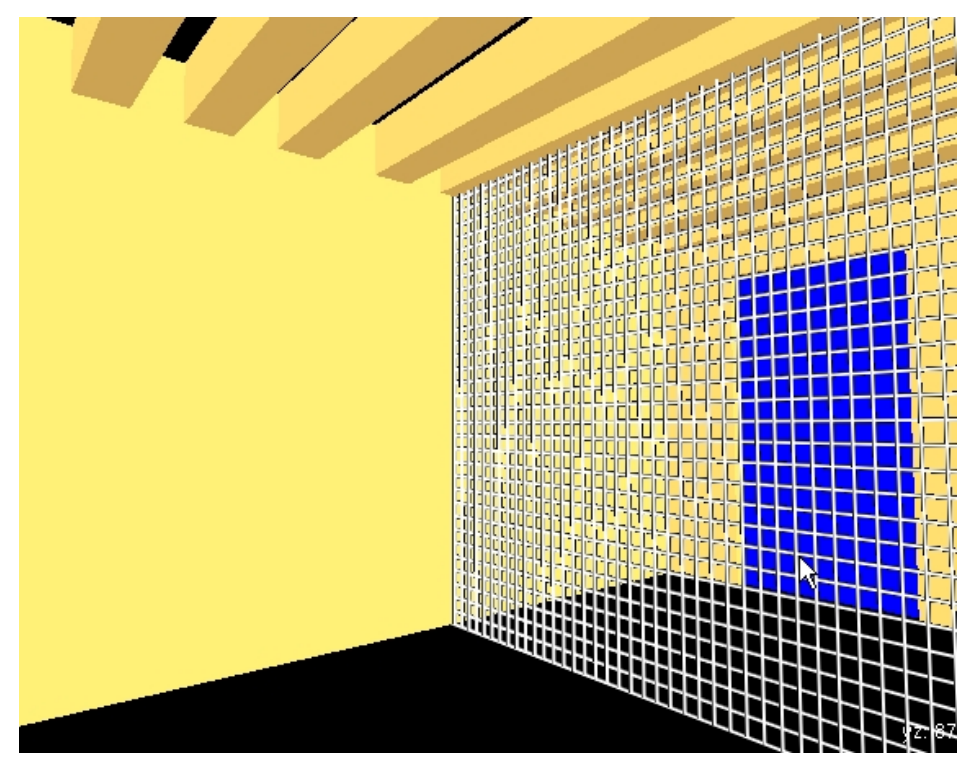

Figure 5. Near the Simulated Fire Source the Simulation Used Smaller Cells (Finer Computational Grid). 


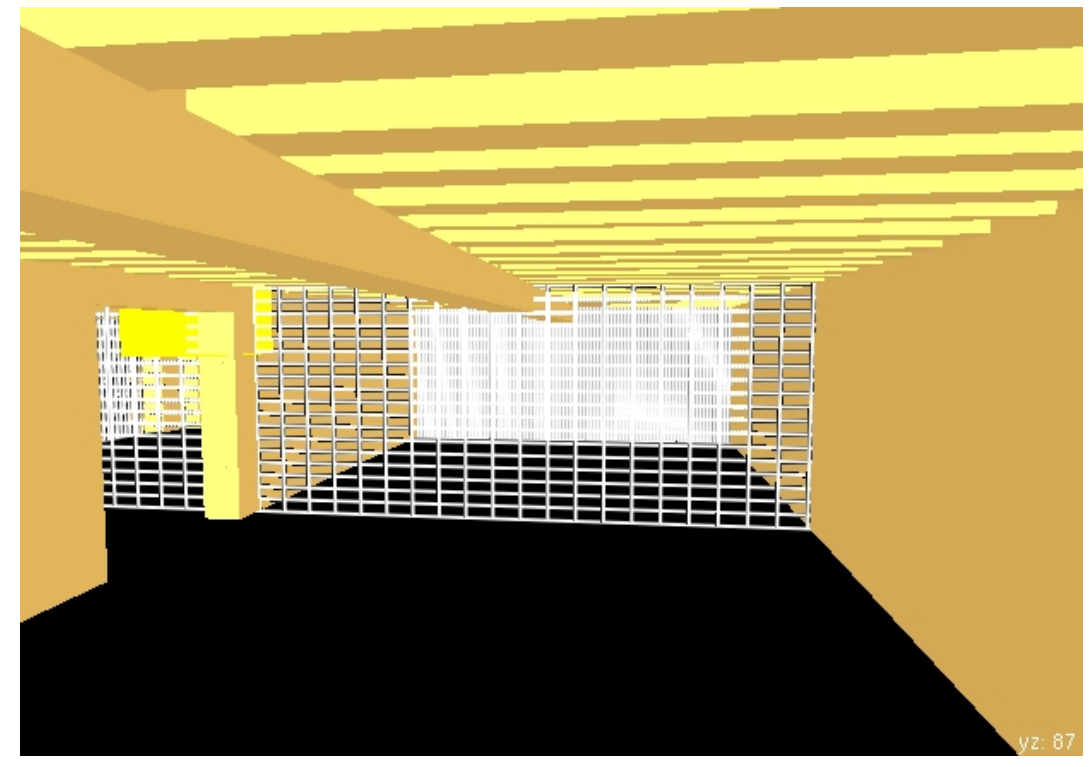

Figure 6. Remote From the Simulated Fire Source the Simulation Used Larger Cells (Coarser Computational Grid).

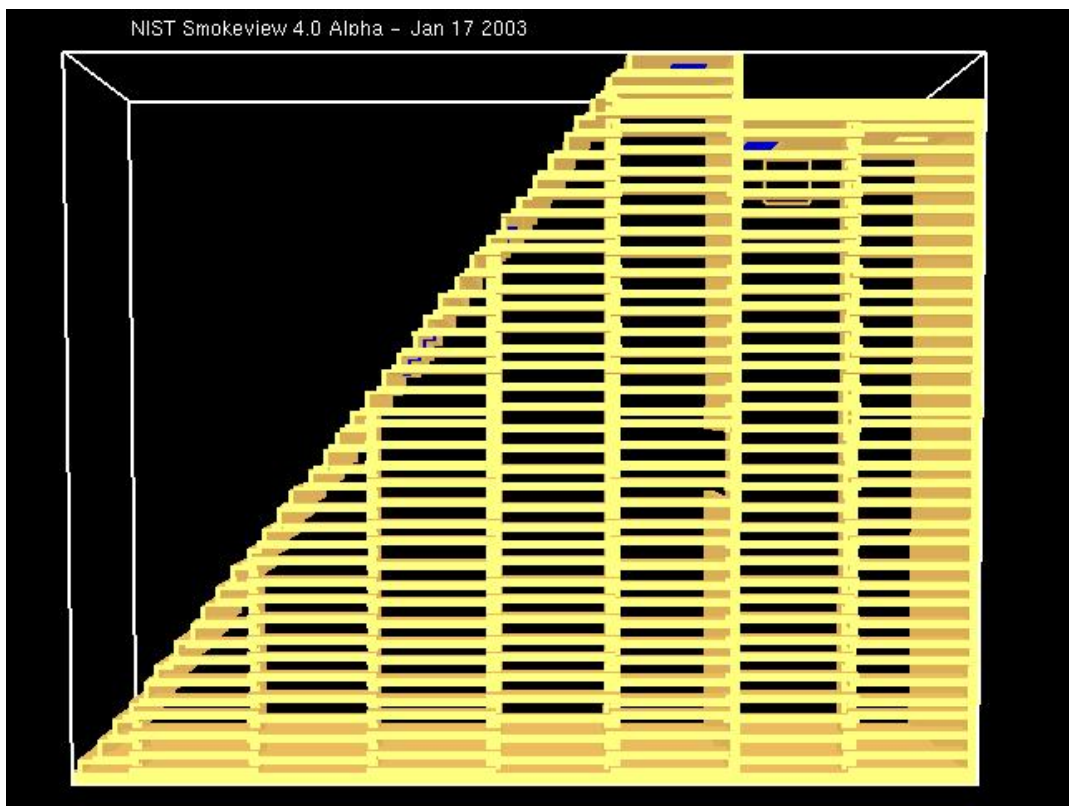

Figure 7. FDS Model Adjusts Walls to Fit Computation Grid and Cells. Note Stepped Wall on Upper Left of Diagram. 
larger heat release rates could cause the gas temperatures to develop more quickly. A burn area of $1 \mathrm{~m}^{2}$ was selected to represent the initial fire burn area.

For each of the fire scenarios, the selected heat release rate, either $500 \mathrm{~kW}, 1000 \mathrm{~kW}$, or $2000 \mathrm{~kW}$, represents the rate at which fuel is supplied to the fire. If there is insufficient oxygen or the gas temperature drops too low in any or all of the computational cells, FDS does not allow the fuel to burn in those affected cells. However, the unburned fuel remains available for combustion if additional oxygen becomes available and/or if gas temperature become high enough for FDS to allow combustion. At any given time step, FDS calculates the total heat released during that time step by first determining which cells will support combustion and then summing the energy released by each of the "allowable" cells.

As the fire burns, it consumes oxygen and fuel. This simulation assumes that the solvents and other fuels in the basement provide additional fuels to replace the fuels consumed by the fire. The relatively high vapor pressure of the liquid solvents supports the assumption that the solvents would be able to evaporate quickly enough to replace the burned fuel. The simulation does limit the maximum rate of fuel evaporation by selecting specific heat release rates. The simulation assumes that only enough fuel to maintain the specific heat release rates is made available at each time step. If one of the solvents, such as acetone, evaporates at a higher rate, this simulation does not consider that additional fuel. While in these fire scenarios FDS assumed there was an adequate and continuous supply of fuel, each fire also required sufficient oxygen.

If the amount of oxygen is limited, as the fire consumes the available oxygen, the fire will decrease in size or "die back" as it becomes "ventilation limited". However the fuel is assumed to continue to evaporate and will accumulate in the room. FDS will not allow combustion to occur in cells without sufficient oxygen. If a vent, such as a window or door opens, additional oxygen may become available. The additional oxygen may allow the fire to grow or increase in terms of heat release rate.

\subsection{Vents}

For the purpose of this simulation, a vent is considered an opening in the building that will allow fire gases to exit the structure and/or ambient air from the outside to enter. For this simulation, all vents were closed to the outside at the beginning of the simulation. At specific times during the simulation, the rear door of Unit 20 and two basement windows in Unit 22 were opened.

As indicated by the estimated timeline (Table 2), the forcible entry team at the rear door of Unit 20 was able to partially open the door, approximately $46 \mathrm{~cm}$ (18 in), at approximately 21 minutes. In the simulation, the rear door in the basement of Unit 20 was partially opened at $1310 \mathrm{~s}$ and this opened a vent $46 \mathrm{~cm}$ wide x $203 \mathrm{~cm}$ high (18 in x 80in ). 


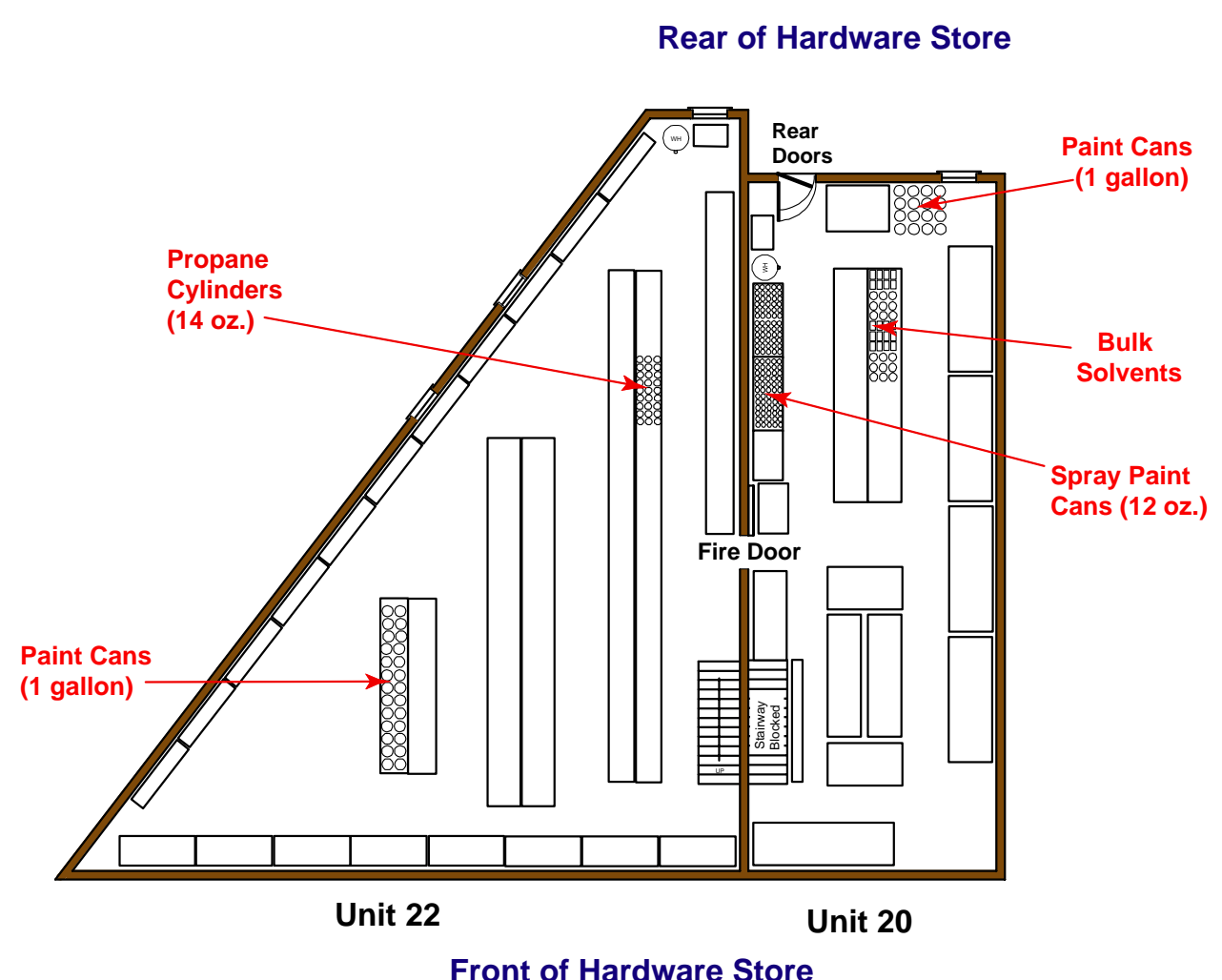

Front of Hardware Store

Figure 8. Location of Paint, Solvents, and Propane in Basement of Hardware Store.

Also as indicated by the estimated timeline (Table 2), additional fire fighters began to open or vent Basement Window \#1 and Basement Window \#2 at between $17 \mathrm{~min}$ and $22 \mathrm{~min}$. In the simulation, it was assumed that the fire fighters required about 3 min to open each window fully. In each computer run, Window \#1 and Window \#2 were opened fully at $22 \mathrm{~min}$ (1300 s) and $27 \mathrm{~min}$ (1600 s), respectively. Each open window was modeled as an open vent with a cross section of $76 \mathrm{~cm}$ wide x $46 \mathrm{~cm}$ high (30” x 18”).

\subsection{Openings Within the Structure}

An opening in the common wall between Unit 20 and Unit 22 allowed easy movement between the two basements. This opening was equipped with a fire door which was designed to close in case of fire. The door itself was located next to this opening and just inside Unit 20 (See Figures 2 and 4). A fusible link that was rated at $74^{\circ} \mathrm{C}\left(165^{\circ} \mathrm{F}\right)$ was located near the ceiling and held the fire door in a retracted position. Upon exposure to 
sufficiently high temperatures, this link would soften or fuse and allow the door to move across the opening and close the doorway. The fire door was allowed to close in three of the computer simulations and was not allowed to close in the other three recreations.

The thermal performance or activation of several Underwriters Laboratory (UL) listed fusible links (designed for fire vents) were examined by McGrattan et al. [9]. For this simulation, it was assumed that the fire door fusible link behaved in a similar manner and after the link reached $74^{\circ} \mathrm{C}\left(165^{\circ} \mathrm{F}\right)$ and remained at that temperature for $65 \mathrm{~s}$, the link would fuse or melt. Once the link was fused, the link would release the door and allow it to close.

As the fire door closed, approximately $60 \%$ of the volume and therefore the oxygen became less available to the fire burning in Unit 20. In the open door simulation, the fire in Unit 20 could have drawn fresh air and oxygen from Unit 22 while hot combustion gases and unburned hydrocarbons would have flowed into Unit 22. How much oxygen was or was not available to the fire would have significantly impacted how fast the fire would have grown and spread in the basement of Unit 20 and eventually extended into Unit 22.

Table 3. Total Heat Release for a Number of Fuels [10].

\begin{tabular}{|c|c|c|c|c|}
\hline Fuel & $\begin{array}{l}\text { Heat } \\
\text { Release } \\
\text { Rate } \\
\text { kW }\end{array}$ & $\begin{array}{l}\text { Total } \\
\text { Heat } \\
\text { Release }^{1} \\
\text { kJ }\end{array}$ & $\begin{array}{l}\text { Burn } \\
\text { Duration }^{2} \\
\quad \mathrm{~s}\end{array}$ & Comments \\
\hline \multirow[t]{2}{*}{ Trash Bags } & 0.6 & 120 & $200 \mathrm{~s}$ & $1.2 \mathrm{~kg}$ cellulosic trash \\
\hline & 1.8 & 360 & $200 \mathrm{~s}$ & $14 \mathrm{~kg}$ cellulosic trash \\
\hline \multirow[t]{2}{*}{ Newspaper } & 0.04 & 4 & $100 \mathrm{~s}$ & Folded, 22 g \\
\hline & 0.9 & 18 & $20 \mathrm{~s}$ & Crumpled, 22 g \\
\hline \multirow[t]{2}{*}{ Wood Pallets $^{3}$} & 1.3 & 200 & $150 \mathrm{~s}$ & 0.55m (18”) high stack \\
\hline & 1.3 & 400 & $310 \mathrm{~s}$ & $0.55 \mathrm{~m}$ (18”) high stack \\
\hline \multirow{2}{*}{$\begin{array}{l}\text { Mail Bags, } \\
\text { filled }^{3}\end{array}$} & 0.4 & 40 & $100 \mathrm{~s}$ & \\
\hline & 0.4 & 80 & $200 \mathrm{~s}$ & \\
\hline \multirow{2}{*}{$\begin{array}{l}\text { Cartons, stacked, } \\
\text { compartmented }^{3}\end{array}$} & 2.3 & 35 & $15 \mathrm{~s}$ & \\
\hline & 2.3 & 70 & $30 \mathrm{~s}$ & \\
\hline \multirow{2}{*}{$\begin{array}{l}\text { Plastic Toy Parts } \\
\text { in cartons }{ }^{3}\end{array}$} & 2.1 & 210 & $100 \mathrm{~s}$ & Polystyrene Plastic \\
\hline & 2.1 & 420 & $200 \mathrm{~s}$ & Polystyrene Plastic \\
\hline \multicolumn{5}{|c|}{$\begin{array}{ll}1 & \text { Total Heat Release = Heat Release Rate x Burn Duration. } \\
2 & \text { Burn duration is time duration of significant burning } \\
3 & \text { Assumes burn area of } 1 \mathrm{~m}^{2} \text { ( } 40 \text { in x } 40 \text { in). }\end{array}$} \\
\hline
\end{tabular}


Table 4. Estimated Energy Content of Solvents in Basement of Hardware Store

\begin{tabular}{|c|c|c|c|c|c|}
\hline \multirow[t]{2}{*}{ Fuel } & \multicolumn{2}{|c|}{$\begin{array}{l}\text { Estimated } \\
\text { Inventory }\end{array}$} & \multicolumn{2}{|c|}{$\begin{array}{c}\text { Estimated } \\
\text { Energy Content }\end{array}$} & \multirow{2}{*}{$\begin{array}{c}\text { Estimated Total } \\
\text { Energy Content } \\
\text { MJ }\end{array}$} \\
\hline & Liters & Gallons & $\mathrm{MJ} / \mathrm{kg}$ & MJ/gallon & \\
\hline Acetone & 45 & 12 & 30.83 & 92 & 1100 \\
\hline Denatured Alcohol & 91 & 24 & 29.67 & 89 & 2100 \\
\hline E-Z Alcohol & 45 & 12 & 33.38 & 99 & 1200 \\
\hline Lacquer Thinner & 91 & 24 & & $90^{1}$ & 2200 \\
\hline Methyl Ethyl Ketone & 91 & 24 & 33.9 & 103 & 2500 \\
\hline Mineral Spirits & 91 & 24 & & $90^{1}$ & 2200 \\
\hline Naphtha & 91 & 24 & & $90^{1}$ & 2200 \\
\hline Paint Thinner & 91 & 24 & & $90^{1}$ & 2200 \\
\hline Toluene & 15 & 4 & 42.4 & 139 & 560 \\
\hline Turpentine & 91 & 24 & & $90^{1}$ & 2200 \\
\hline \multirow[t]{2}{*}{ Xylene } & 15 & 4 & 42.9 & 143 & 570 \\
\hline & Volume & Number & $\mathrm{MJ} / \mathrm{kg}$ & MJ/containe & \\
\hline Propane Cylinder & $\begin{array}{l}0.42 \mathrm{~kg} \\
(14 \mathrm{oz} .)\end{array}$ & 142 & 50.35 & 21 & 3000 \\
\hline Spray Paint Aerosol Can & $\begin{array}{l}0.36 \mathrm{~kg} \\
(12 \mathrm{oz} .)\end{array}$ & 300 & $50.35^{2}$ & 18 & 1360 \\
\hline
\end{tabular}

${ }^{1}$ These solvents are mixtures of linear and branched alkanes, cycloalkanes, and aromatic hydrocarbons. Their energy content was approximated by assuming a value of 23.8 MJ/ liter (90 MJ/gallon)

${ }^{2}$ Spray Paint Aerosol Can was assumed to be $75 \%$ paint compounds and $25 \%$ propane propellant. Energy content was approximated by assuming the value for propane for $25 \%$ of the mass of each can. 
Table 6. Time of Ventilation Events for FDS Simulation

\begin{tabular}{|l|c|c|c|}
\hline \multicolumn{2}{|l|}{} & \multicolumn{1}{|c|}{$\begin{array}{c}\text { Fire Door } \\
\text { Allowed } \\
\text { to Close }\end{array}$} & $\begin{array}{c}\text { Fire Door } \\
\text { Remained } \\
\text { Open }\end{array}$ \\
\hline \multicolumn{1}{|c|}{ Vent } & $\begin{array}{c}\text { Initial } \\
\text { Conditions }\end{array}$ & \multicolumn{2}{|c|}{ Time of Event, s } \\
\hline $\begin{array}{l}\text { Rear Door } \\
\text { Unit 20 }\end{array}$ & Closed & $\begin{array}{c}1310 \\
\text { Partially Open }\end{array}$ & $\begin{array}{c}1310 \\
\text { Partially Open }\end{array}$ \\
\hline $\begin{array}{l}\text { Basement Window \# 1 } \\
\text { Unit 22 }\end{array}$ & Closed & $\begin{array}{c}1300 \\
\text { Fully Open }\end{array}$ & Fully Open \\
\hline $\begin{array}{l}\text { Basement Window \# 2 } \\
\text { Unit 22 }\end{array}$ & Closed & Fully Open & Fully Open \\
\hline Note - Partially Open = Rear door was opened 46 cm (18 in). \\
\hline
\end{tabular}

\subsection{Material Properties}

When a wall, ceiling, truss, piece of furniture, or any other structural item or piece of furniture is defined for use in the FDS model it is given a set of physical and thermal properties that are used by the model. A list of the materials used in these simulations along with the physical and thermal properties required by FDS is given in Table 7 [5]. The first floor joists and subfloor used in this structure were made of wood. In the simulation these wooden components were given the thermal characteristics of oak. The floor joists were assigned a thickness of $0.1 \mathrm{~m}$ ( 4 in). The under side of the first floor or the subfloor was assigned a thickness of $0.02 \mathrm{~m}$ ( $0.75 \mathrm{in}$ ). The floor and walls in both basements were given the thermal characteristics of concrete with a thickness of $0.2 \mathrm{~m}$ ( 8 in). The thermal properties of the materials were used by FDS to calculate heat transfer and determine when these materials ignite and their contribution to the heat release rate of the fire. 
Table 7. Thermal Properties Data

\begin{tabular}{|c|c|c|c|}
\hline & \multicolumn{3}{|c|}{ Material } \\
\hline Thermal Property & Units & $\begin{array}{c}\text { Floor and Walls } \\
\text { Concrete }\end{array}$ & $\begin{array}{c}\text { Wood Components } \\
\text { Hardwood - Oak }\end{array}$ \\
\hline Thickness & $\mathrm{m}$ & 0.20 & $\begin{array}{c}0.02 \text { (subfloor) } \\
0.1 \text { (joists) }\end{array}$ \\
\hline Ignition Temperature & ${ }^{\circ} \mathrm{C}$ & Not applicable & 340 \\
\hline Thermal Conductivity & $\mathrm{W} / \mathrm{m} \mathrm{K}$ & 1.0 & 0.17 \\
\hline Thermal Diffusivity & $\mathrm{m} / \mathrm{s}$ & $5.7 \times 10^{-7}$ & $4.9 \times 10^{-8}$ \\
\hline Heat of Vaporization & $\mathrm{kJ} / \mathrm{kg}$ & Not applicable & 13000 \\
\hline Heat of Combustion & $\mathrm{kJ} / \mathrm{kg}$ & Not applicable & 4000 \\
\hline
\end{tabular}

\section{Model Results}

The fire spread and growth in the basement of the hardware store was simulated using three different initial fire heat release rates: $500 \mathrm{~kW}, 1000 \mathrm{~kW}$, and $2000 \mathrm{~kW}$. Each different heat release rate was replicated with the fire door open (not allowed to close when fusible link melted) and the fire door closed (allowed to close when fusible link softened or melted). For each simulation, the temperature and oxygen concentration was tracked at different locations within Unit 20 and Unit 22.

\subsection{Model Geometry and Iso-Surfaces Output}

Figure 9 displays the view generated within the model simulation from the front of Unit 20 looking towards the rear door. For each case, the fire was positioned just inside the rear basement door for Unit 20 and is outlined as a square on the floor in Figure 10.

Figures 11 - 22 show plots of iso-surfaces for an initial $500 \mathrm{~kW}$ fire source with the door open. Iso-surfaces are calculated by FDS at locations where the mixture of fuel and oxygen are sufficient to support combustion. While not precise, iso-surfaces can provide a qualitative feel for where the fire might be burning. In this simulation, Basement Window \#1 was opened at $1300 \mathrm{~s}$ and the rear door was partially opened at simulation time of $1310 \mathrm{~s}$. The model simulation indicates that as the additional oxygen entered the basement of Unit 20 additional burning occurred (compare Figure 19 at $1311 \mathrm{~s}$ and Figure 20 at 1324 s). The orange/yellow "flame" surface spreads across the ceiling as the 


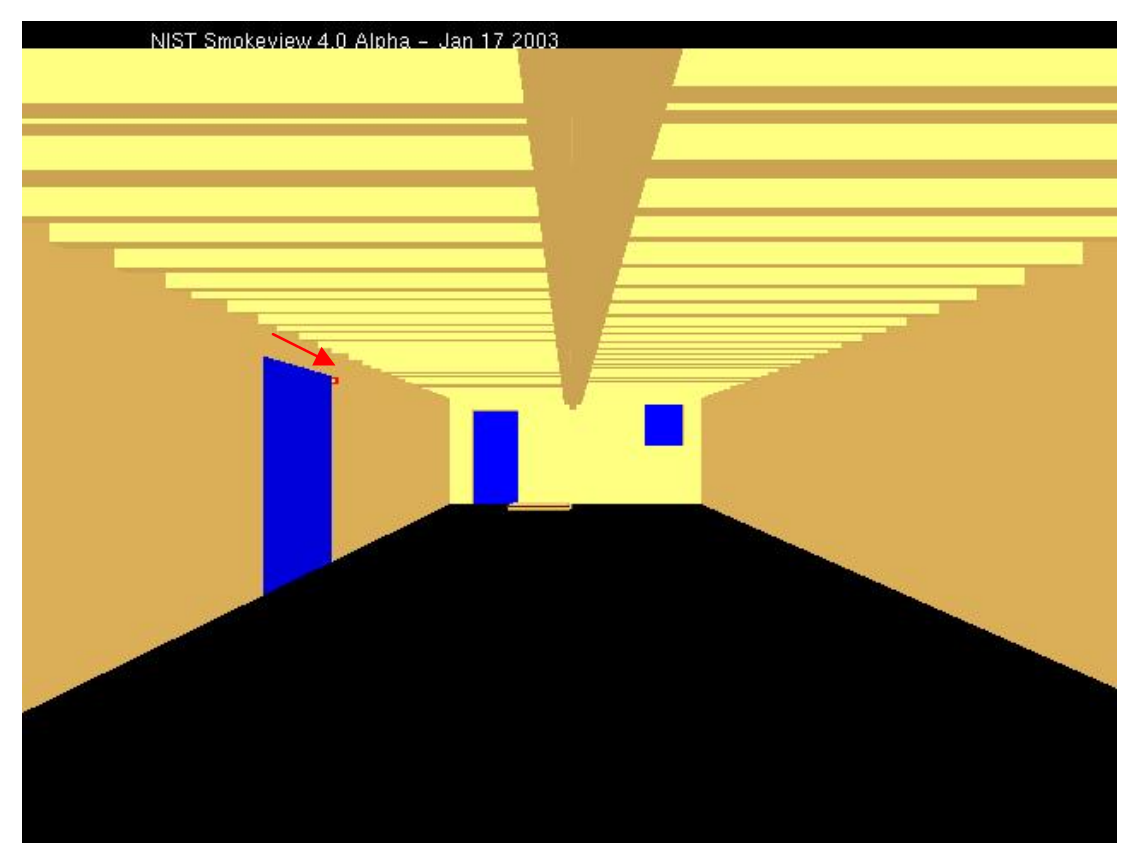

Figure 9. View Generated by Model Simulation Looking from Front of Unit 20 Towards Rear Door. Fire Door Opening Located in Wall on Left. Note Red Dot at Upper Right Corner of Fire Door Opening. Red Dot Indicates Position of Fire Door Thermocouple (next to location of fusible link).

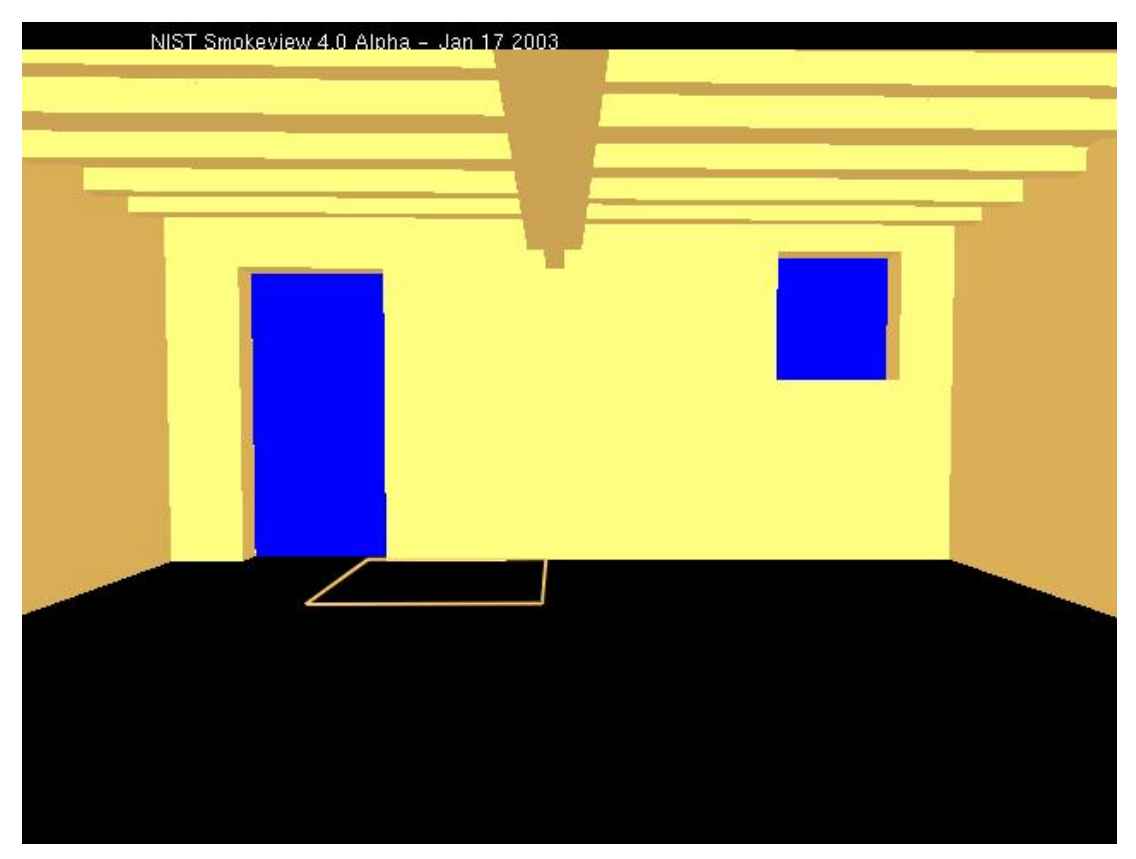

Figure 10. Fire Positioned Just Inside Rear Door of Unit 20. 


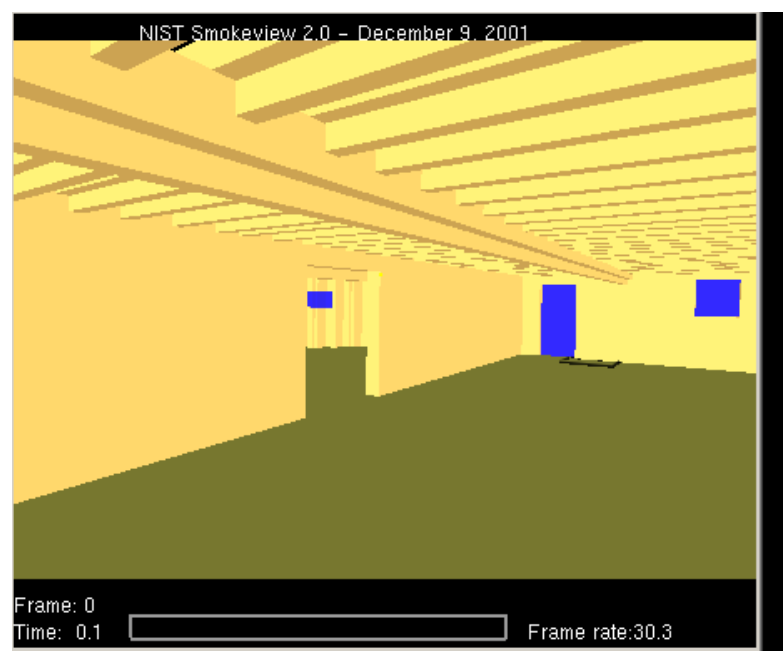

Figure 11. Iso-Surface Plot for an Initial $500 \mathrm{~kW}$ Fire Source. Fire at Time $=0 \mathrm{~s}$.

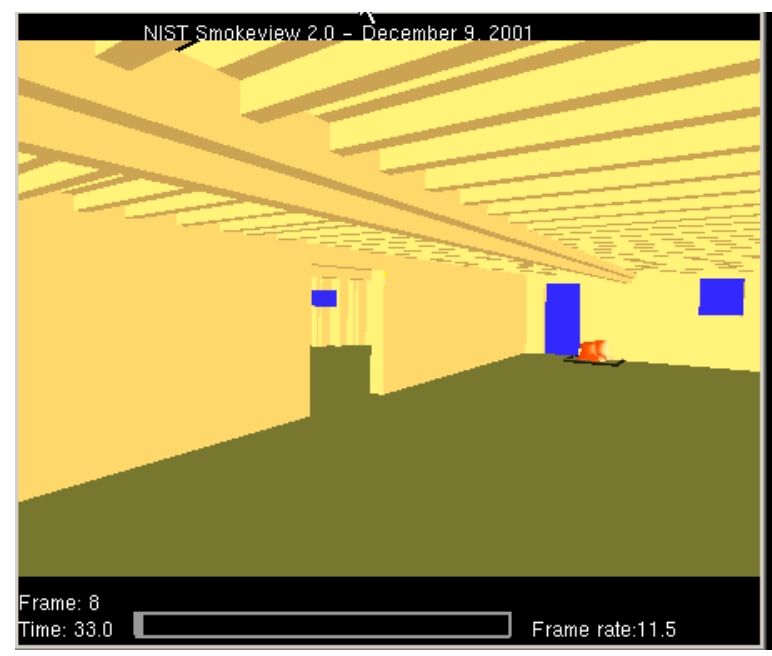

Figure 13. Iso-Surface Plot for an Initial $500 \mathrm{~kW}$ Fire Source. Fire at Time $=33 \mathrm{~s}$.

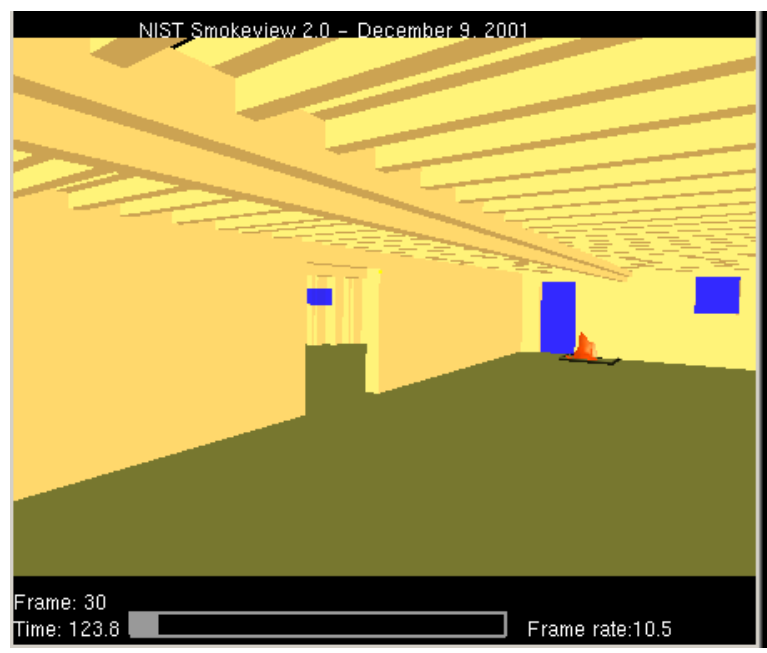

Figure 15. Iso-Surface Plot for an Initial $500 \mathrm{~kW}$ Fire Source. Fire at Time $=120 \mathrm{~s}$.

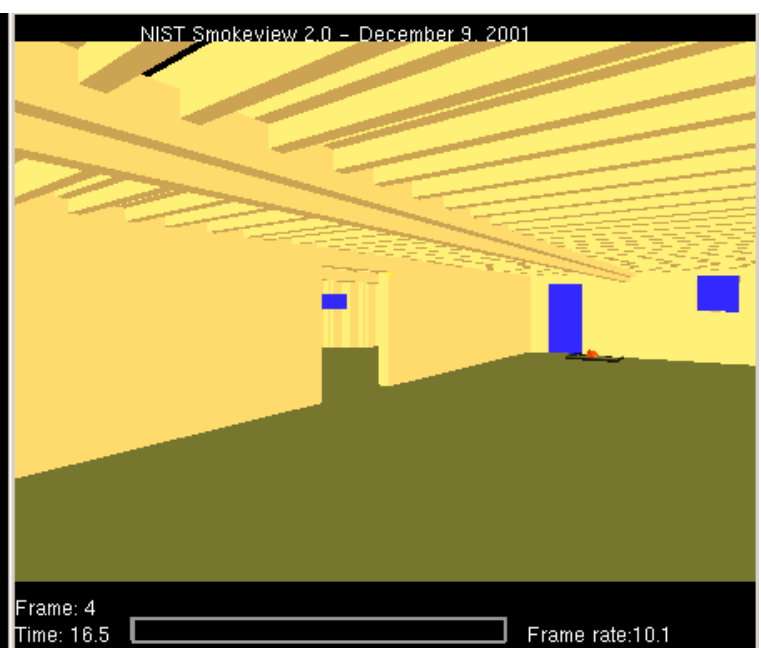

Figure 12. Iso-Surface Plot for an Initial $500 \mathrm{~kW}$ Fire Source. Fire at Time $=16 \mathrm{~s}$.

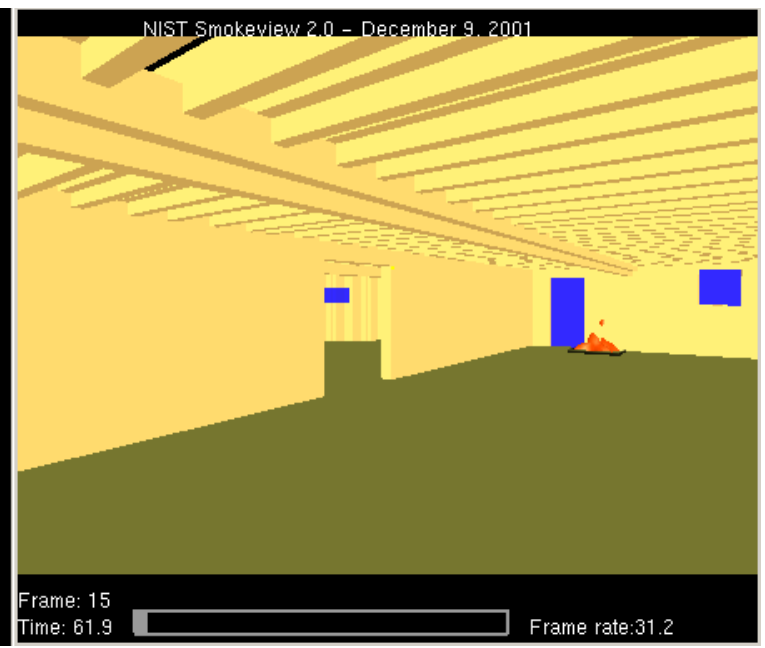

Figure 14. Iso-Surface Plot for an Initial $500 \mathrm{~kW}$ Fire Source. Fire at Time $=62 \mathrm{~s}$.

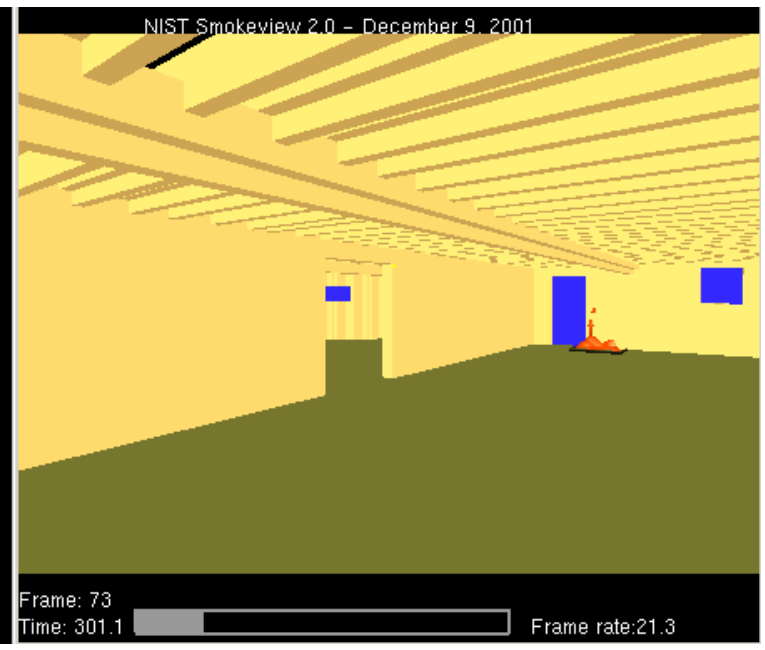

Figure 16. Iso-Surface Plot for an Initial $500 \mathrm{~kW}$ Fire Source. Fire at Time $=300 \mathrm{~s}$. 


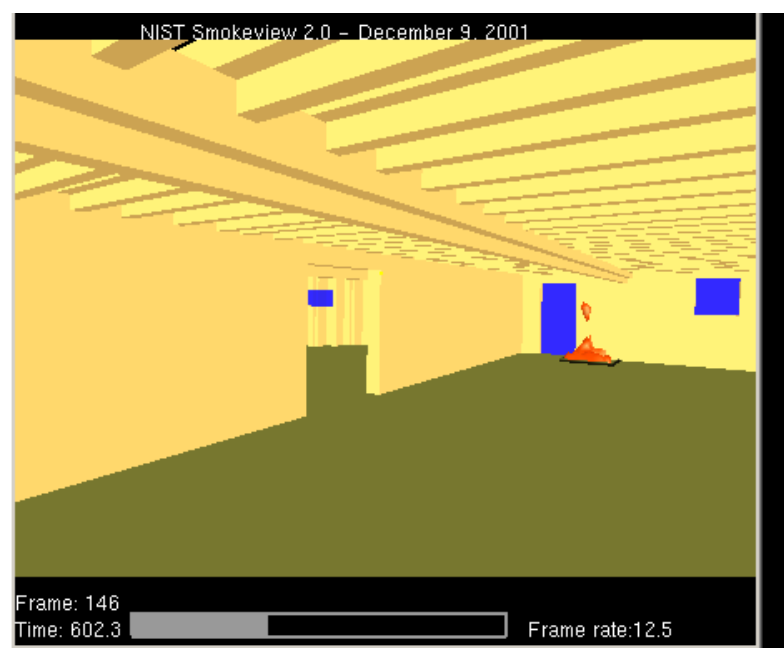

Figure 17. Iso-Surface Plot for an Initial $500 \mathrm{~kW}$ Fire Source. Fire at Time $=600 \mathrm{~s}$.

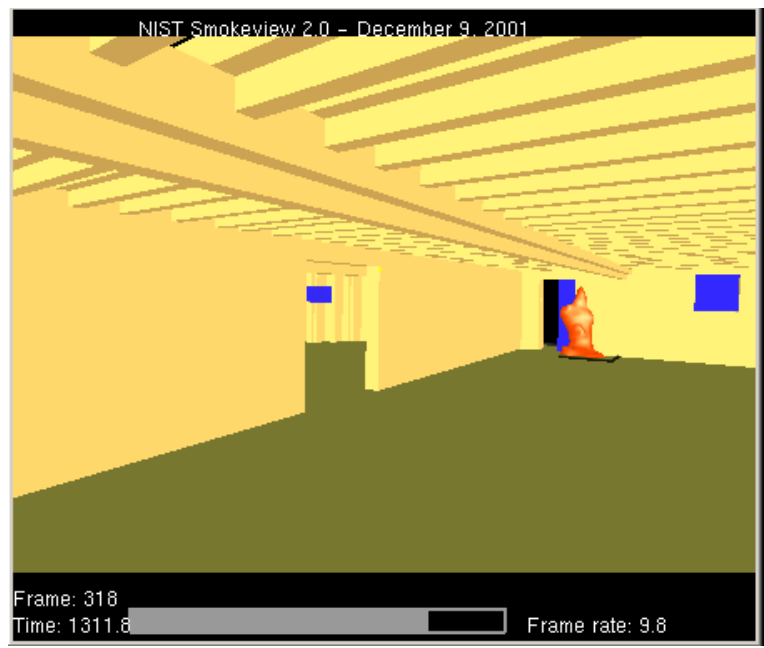

Figure 19. Iso-Surface Plot for an Initial $500 \mathrm{~kW}$ Fire Source. Fire at Time $=1311 \mathrm{~s}$.

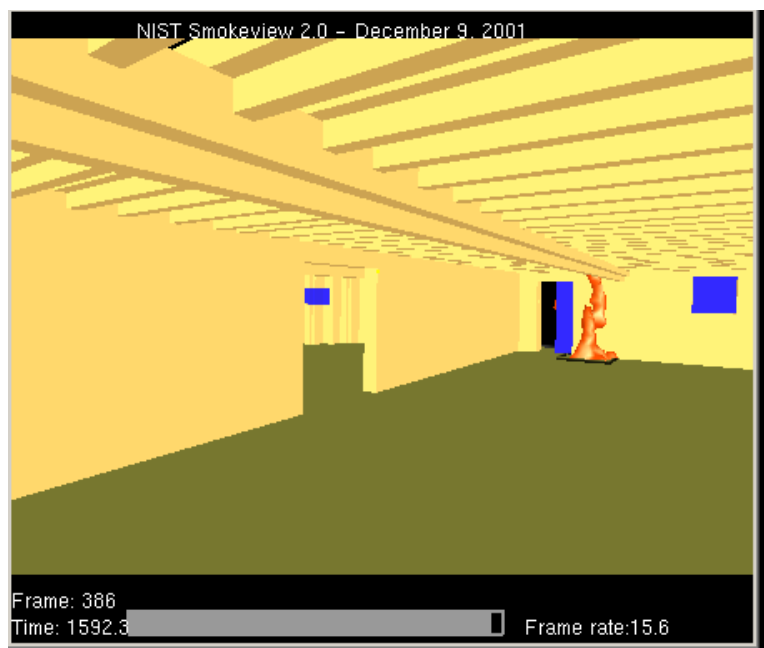

Figure 21. Iso-Surface Plot for an Initial $500 \mathrm{~kW}$ Fire Source. Fire at Time $=1592 \mathrm{~s}$.

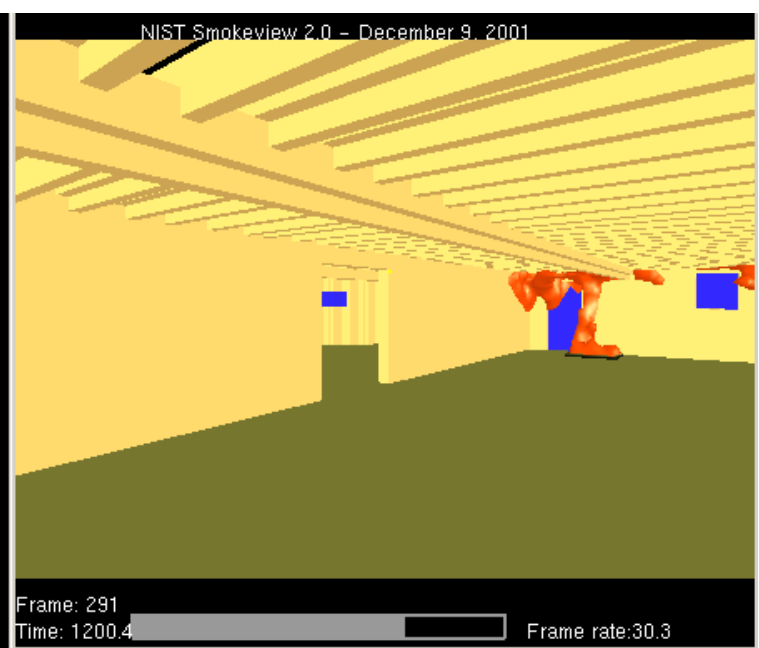

Figure 18. Iso-Surface Plot for an Initial $500 \mathrm{~kW}$ Fire Source. Fire at Time $=1200 \mathrm{~s}$.

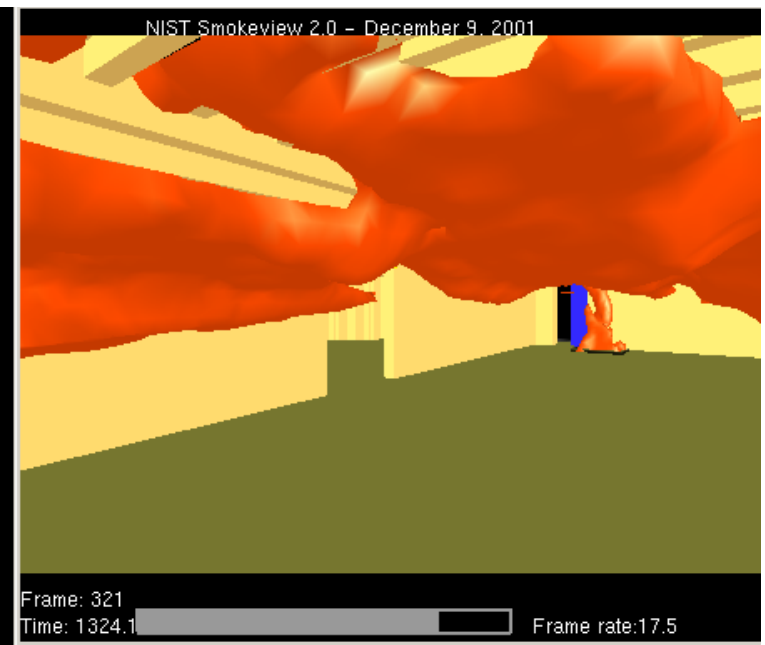

Figure 20. Iso-Surface Plot for an Initial $500 \mathrm{~kW}$ Fire Source. Fire at Time $=1324 \mathrm{~s}$.

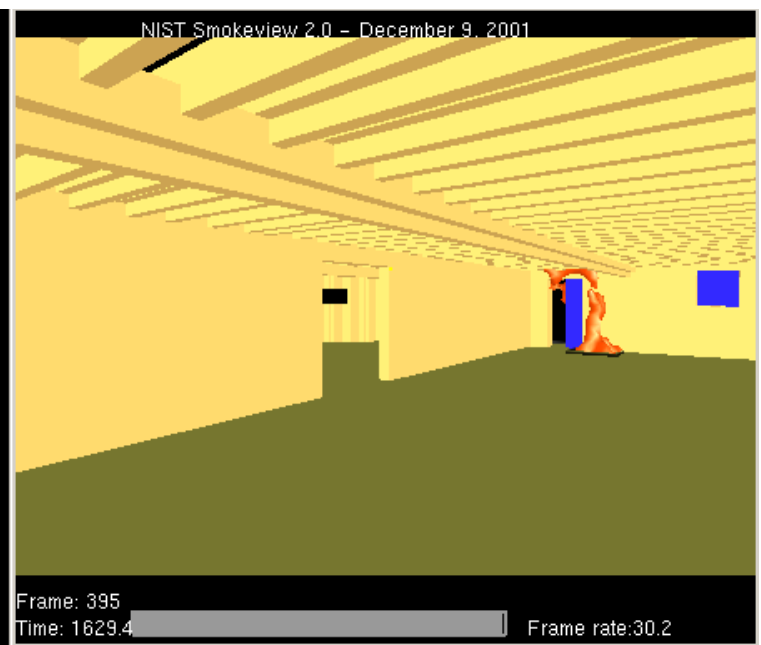

Figure 22. Iso-Surface Plot for an Initial $500 \mathrm{~kW}$ Fire Source. Fire at Time $=1629 \mathrm{~s}$. 
additional oxygen flows through the basement and allows more of the computational cells to meet the requirements for combustion. However, once the oxygen and fuel are consumed or the gas temperature drops low enough, the cells no longer meet the requirements for combustion, so less heat is released. Over the next $450 \mathrm{~s}$, the fire decreases or "dies back" and the orange/yellow flame retreats back to a fire near the rear door of Unit 20 as shown in the iso-surface plot at $1592 \mathrm{~s}$ (Figure 21).

\subsection{Fire Simulation -Temperature and Oxygen Concentration Predictions}

The Fire Dynamic Simulator computer model calculates the velocity, direction, temperature, and composition of the combustion gases, smoke density, and thermal radiation, material ignition and heat release rate within each computational cell (see Figures 5 and 6) for each time step during the simulation. This data can be displayed as a slice that extends front to back or side to side of the structure. For this reconstruction, the gas temperatures and oxygen concentrations were recreated using FDS. A sliding color scale can help the reader to visualize the distribution of temperatures or oxygen concentration across the basement of Unit 20 and 22.

For each oxygen data slice, the lower end of the color bar, blue, corresponds to zero oxygen concentration while the upper end, red, matches up with ambient $21 \%$ oxygen ( $0.21 \mathrm{~mol}$ concentration of oxygen). As each fire grows, it consumes oxygen and the color changes from red (21\% oxygen) to blue (zero oxygen). At some point in the fire growth, the lack of oxygen will slow the growth of the fire and if additional oxygen is not provided, the fire will stop burning. If a vent, such as a door is opened, then additional oxygen may flow into the room and the color would change from blue to green to yellow and eventually to red as the oxygen concentrations reach $21 \%$. If the fire door has closed and isolated Unit 20 from Unit 22, then the oxygen concentrations could be significantly different in the two units.

For each temperature data slice, the lower end of the color bar, blue, corresponds to less than $20^{\circ} \mathrm{C}\left(68{ }^{\circ} \mathrm{F}\right)$ or gas at ambient room temperature while the upper end, red, matches up with the highest gas temperature for that specific fire. Any gas temperature higher than the maximum temperature on the color scale is displayed as red. For example, if the color bar ranges from $20^{\circ} \mathrm{C}$ to $340^{\circ} \mathrm{C}\left(68^{\circ} \mathrm{F}\right.$ to $\left.644^{\circ} \mathrm{F}\right)$, and the flame zone reached gas temperatures of $1200^{\circ} \mathrm{C}\left(2200^{\circ} \mathrm{F}\right)$, the flame zone would be colored red. As each fire grows, the gas temperatures increase and change from blue to green to yellow and finally to red. If the fire becomes ventilation limited, too little oxygen or too much fuel, then the fire could stop growing and may extinguish itself. In this case, the gas temperatures would start cool (blue) and increase to hot (red) and then might cool down again (blue). If the fire door has closed and isolated Unit 20 from Unit 22, then the gas temperatures could be significantly different in the two units.

\section{Fire Simulations With Fire Door Allowed to Close - 500 kW, 1000 kW, and 2000 kW}

Figures 23 through 32 show the temperatures and oxygen concentrations in Unit 20 and 22 for an initial $500 \mathrm{~kW}$ fire source at times of 118 s, 126 s, 586 s, and 1088 s. Each gas 
temperature plot on the left is paired with its corresponding oxygen concentration plot on the right side. The fire door is open initially and as the fire grows the gas temperatures reach high enough values to melt or fuse the fusible link and the door closes at $126 \mathrm{~s}$. The closed fire door appears as a solid blue surface in the temperature slices and as a solid blue rectangle in the oxygen slices. The temperature of a simulated thermocouple placed near the fusible link was tracked throughout the fire and used to determine when the fusible link might soften or melt and release the fire door. In the temperature slice figures, the thermocouple near the fusible link is visible as a small green square at the upper rear corner of the fire door. The thermocouple temperatures near the fusible link will be discussed later in this report.

As can be observed from the temperature slices, the fire develops gas temperatures near the center of Unit 20 in excess of $200^{\circ} \mathrm{C}\left(392^{\circ} \mathrm{F}\right)$ in less than $120 \mathrm{~s}$. These high temperatures are sufficient to cause the fire door to close. By $586 \mathrm{~s}$, the gas temperatures are decreasing significantly until by $1088 \mathrm{~s}$, the gas temperatures in most of Unit 20 appear near $20{ }^{\circ} \mathrm{C}\left(68^{\circ} \mathrm{F}\right)$. The oxygen slices demonstrate that in the beginning, the fire can draw oxygen from Unit 20 and 22, but after 126 s, the fire only has access to the oxygen

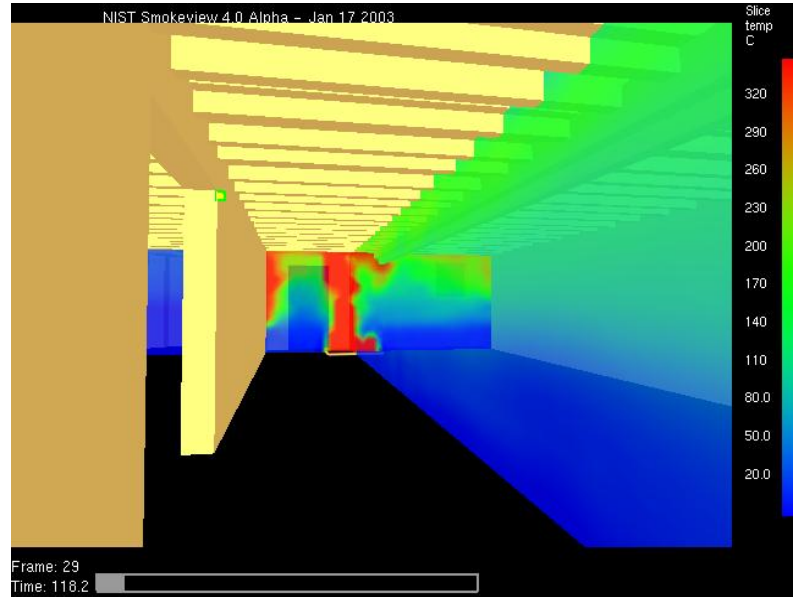

Figure 23. Temperature Profiles for an Initial $500 \mathrm{~kW}$ Fire Source. Fire At Time $=118 \mathrm{~s}$.

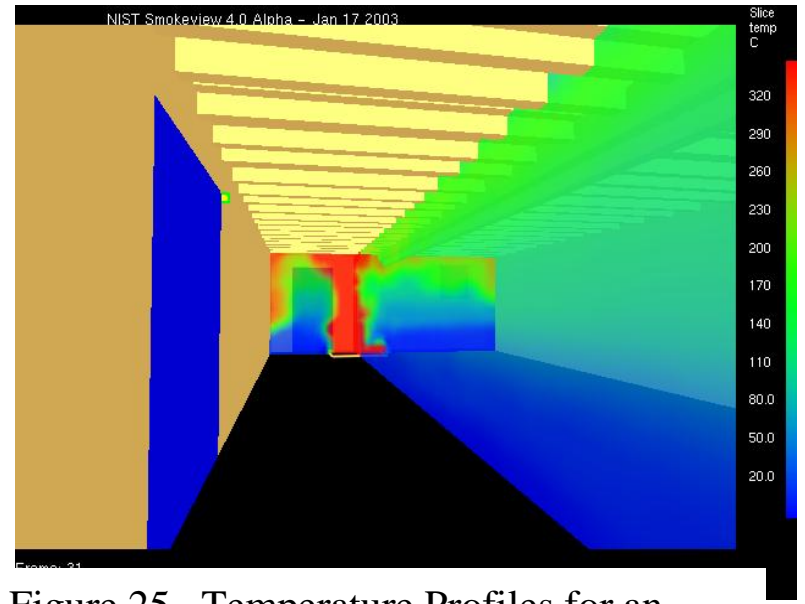

Figure 25. Temperature Profiles for an Initial $500 \mathrm{~kW}$ Fire Source. Fire At Time = 126 s. Fire Door Closed at 126 s.

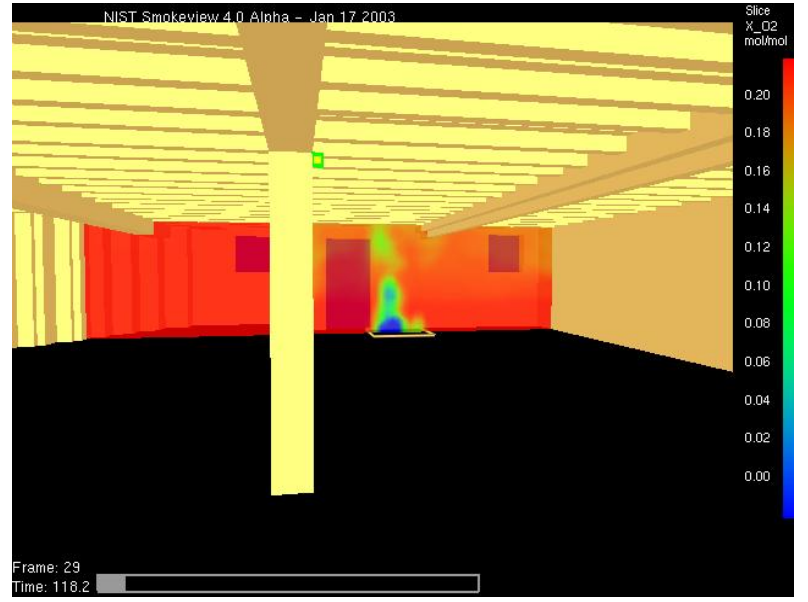

Figure 24. Oxygen Concentrations for an Initial $500 \mathrm{~kW}$ Fire Source. Fire At Time $=118$ s. Fire Door is Open.

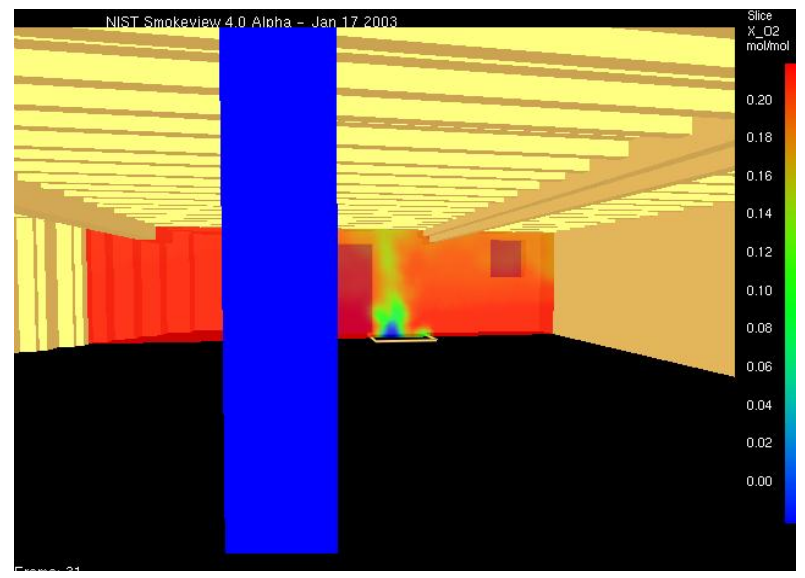

Figure 26. Oxygen Concentrations for an Initial $500 \mathrm{~kW}$ Fire Source. Fire At Time $=126 \mathrm{~s}$. Fire Door Closed at $126 \mathrm{~s}$. 


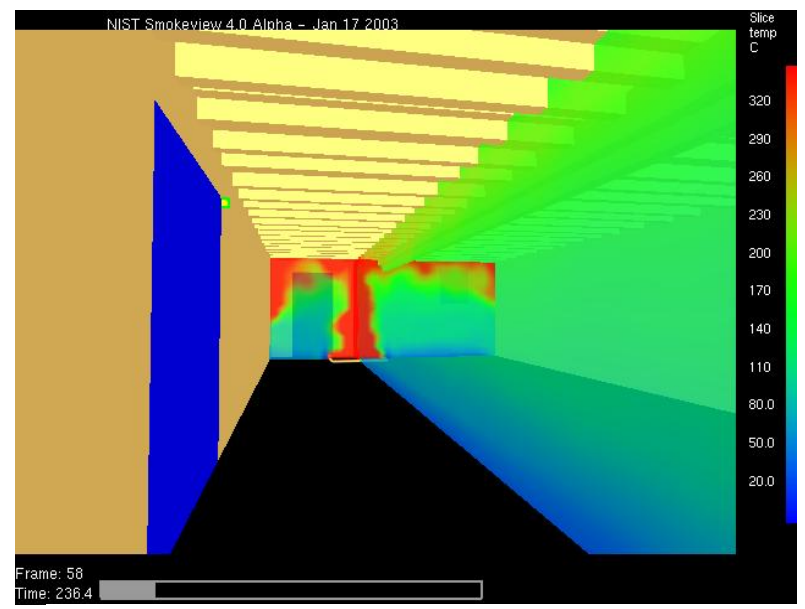

Figure 27. Temperature Profiles for an Initial $500 \mathrm{~kW}$ Fire Source. Fire At

Time $=236 \mathrm{~s}$. Fire Door Closed at $126 \mathrm{~s}$.

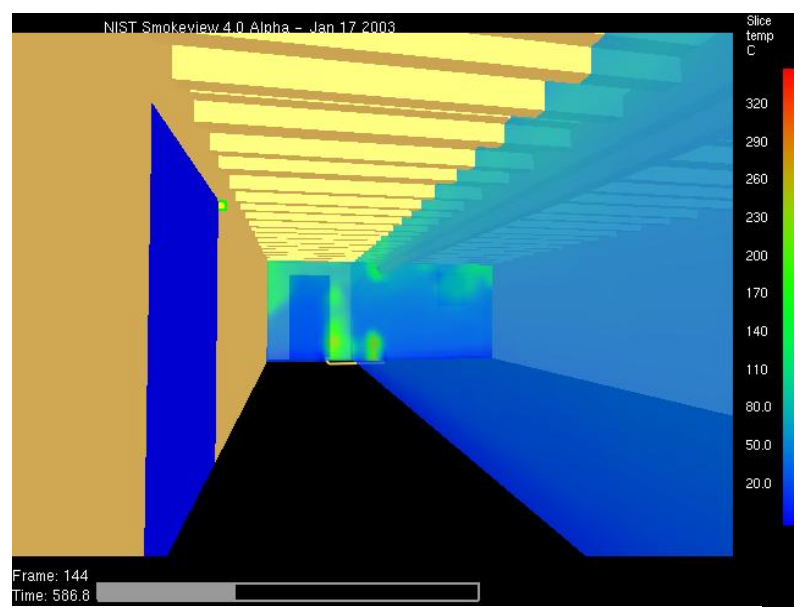

Figure 29. Temperature Profiles for an Initial $500 \mathrm{~kW}$ Fire Source. Fire At Time $=586 \mathrm{~s}$. Fire Door Closed at 126

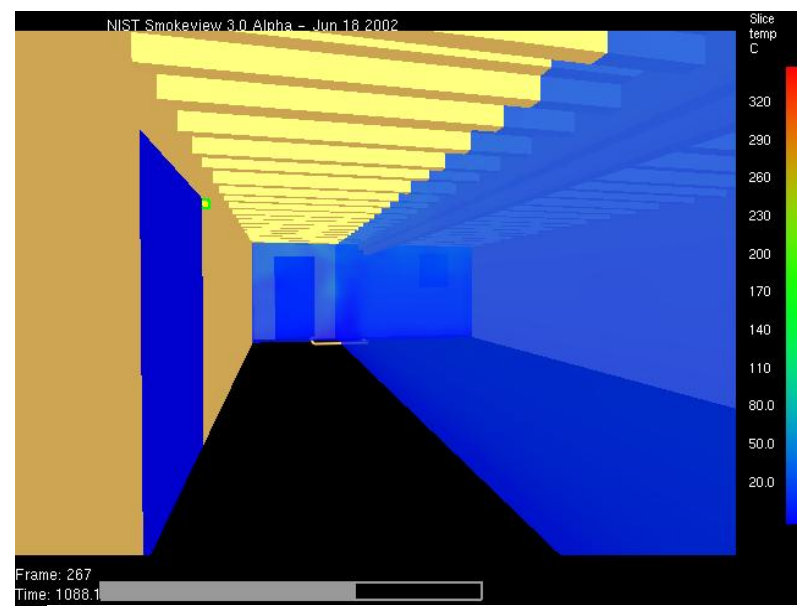

Figure 31. Temperature Profiles for an Initial 500 kW Fire Source. Fire At Time $=1088 \mathrm{~s}$. Fire Door Closed at $126 \mathrm{~s}$.

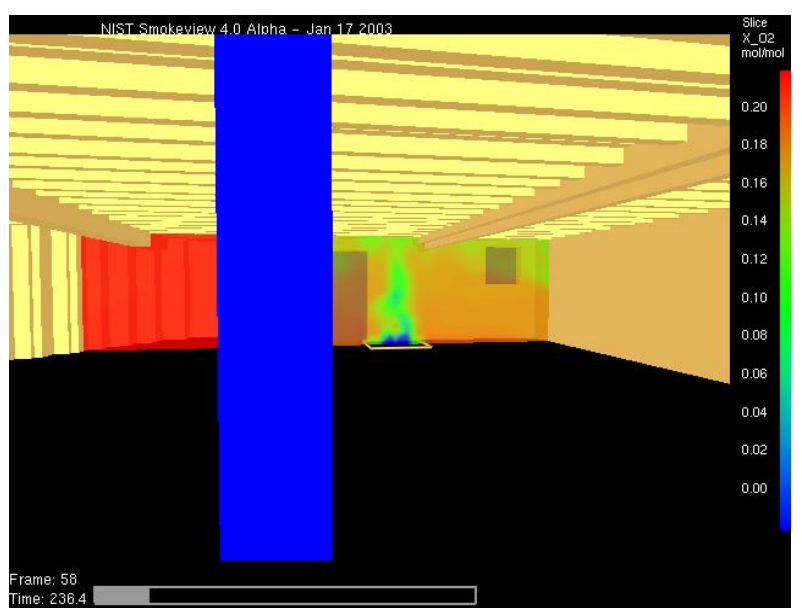

Figure 28. Oxygen Concentrations for an Initial $500 \mathrm{~kW}$ Fire Source. Fire At Time $=236 \mathrm{~s}$. Fire Door Closed at $126 \mathrm{~s}$.

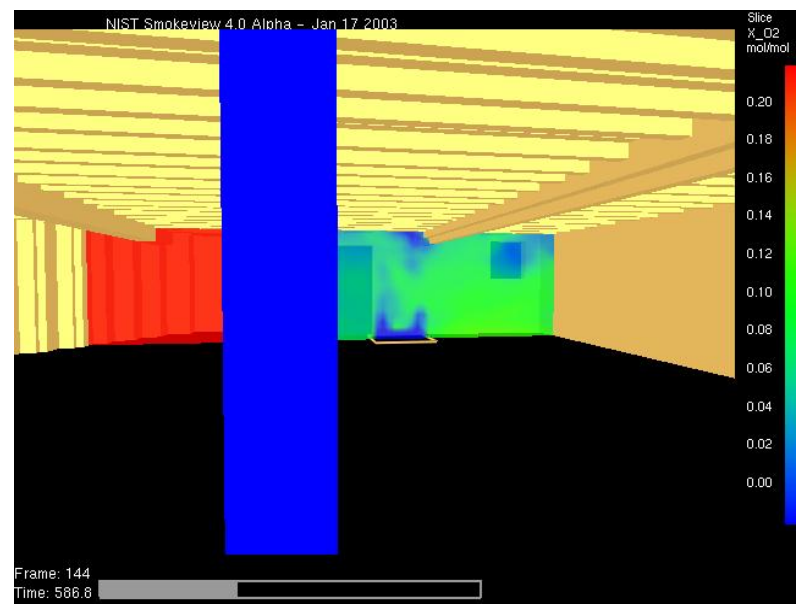

Figure 30. Oxygen Concentrations for an Initial $500 \mathrm{~kW}$ Fire Source. Fire At Time $=586 \mathrm{~s}$. Fire Door Closed at $126 \mathrm{~s}$.

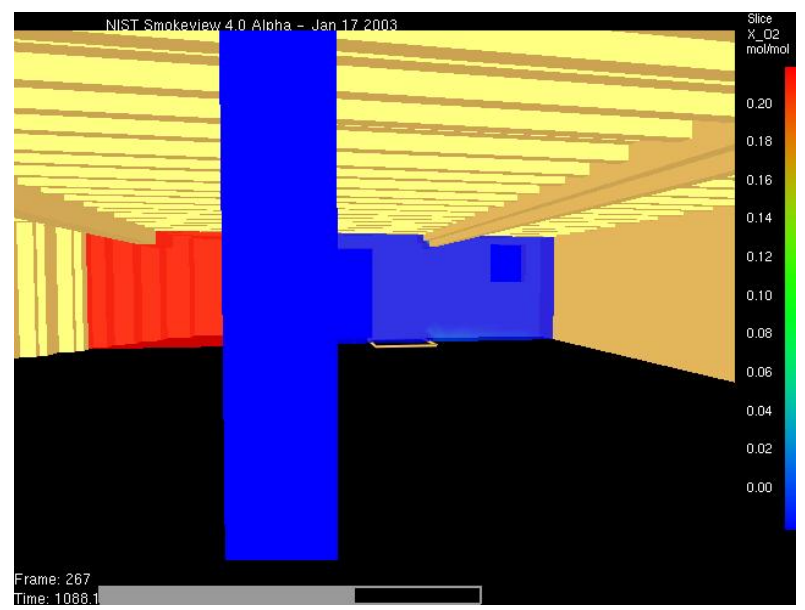

Figure 32. Oxygen Concentrations for an Initial $500 \mathrm{~kW}$ Fire Source. Fire At Time $=1088 \mathrm{~s}$. Fire Door Closed at $126 \mathrm{~s}$. 
in Unit 20. By $375 \mathrm{~s}$, the fire has consumed enough oxygen to reduce the concentration below the $15 \%$ concentration necessary to allow combustion below $300{ }^{\circ} \mathrm{C}\left(570{ }^{\circ} \mathrm{F}\right)$ in Unit 20. While FDS does allows some additional burning to occur at lower oxygen concentrations and higher temperatures, the unburned fuel is still accumulating in Unit 20. By 586 s, the fire has dropped the oxygen concentrations to less than $10 \%$ and appears to have consumed all the oxygen in the rear of Unit 20 by $1088 \mathrm{~s}$.

Figures 33 through 44 show the temperatures and oxygen concentrations in Unit 20 and 22 for a $1000 \mathrm{~kW}$ fire at times of $73 \mathrm{~s}, 81 \mathrm{~s}, 126 \mathrm{~s}, 224 \mathrm{~s}, 428 \mathrm{~s}$, and $767 \mathrm{~s}$. The fire door is open initially and as the fire grows the gas temperatures reach high enough values to soften or melt the fusible link and the door closes at $81 \mathrm{~s}$.

As can be observed from the temperature slices, the fire develops gas temperatures near the center of Unit 20 in excess of $200^{\circ} \mathrm{C}\left(392^{\circ} \mathrm{F}\right)$ in less than $120 \mathrm{~s}$. These high temperatures are sufficient to cause the fire door to close. By $428 \mathrm{~s}$, the gas temperatures are decreasing significantly until by $767 \mathrm{~s}$, most of the gas temperatures in Unit 20 appear near $20{ }^{\circ} \mathrm{C}\left(68^{\circ} \mathrm{F}\right)$. As one might expect, the higher heat release fire, $1000 \mathrm{~kW}$ instead of 500 $\mathrm{kW}$, causes the gas temperatures to increase more quickly and the oxygen to be consumed more quickly. The oxygen slices demonstrate that in the beginning, the fire can draw oxygen from Unit 20 and 22, but after $81 \mathrm{~s}$, the fire only has access to the oxygen in Unit 20. By $204 \mathrm{~s}$, the fire has consumed enough oxygen to reduce the concentration below the $15 \%$ concentration necessary to allow combustion below $300^{\circ} \mathrm{C}\left(570{ }^{\circ} \mathrm{F}\right)$ in Unit 20. While FDS does allows some additional burning to occur at lower oxygen concentrations and higher temperatures, the unburned fuel is still accumulating in Unit 20. By $428 \mathrm{~s}$, the fire has dropped the oxygen concentrations to less than $6 \%$ and appears to have consumed all the oxygen in the rear of Unit 20 by 767 s.

Figures 45 through 54 show the temperatures and oxygen concentrations in Unit 20 and 22 for a $2000 \mathrm{~kW}$ fire at times of $53 \mathrm{~s}, 57 \mathrm{~s}, 90 \mathrm{~s}, 183 \mathrm{~s}$, and $375 \mathrm{~s}$. The fire door is open initially and as the fire grows the gas temperatures reach high enough values to activate the fusible link and the door closes at $57 \mathrm{~s}$.

As can be observed from the temperature slices, the fire develops gas temperatures near the center of Unit 20 in excess of $200{ }^{\circ} \mathrm{C}\left(392^{\circ} \mathrm{F}\right)$ in less than $60 \mathrm{~s}$. These high temperatures are sufficient to cause the fire door to close. By $183 \mathrm{~s}$, the gas temperatures are decreasing significantly until by 375 s, most of the gas temperatures in Unit 20 appear less than $150^{\circ} \mathrm{C}\left(300^{\circ} \mathrm{F}\right)$. As one might expect, the higher heat release fire, $2000 \mathrm{~kW}$ instead of $500 \mathrm{~kW}$ or $1000 \mathrm{~kW}$, causes the gas temperatures to increase more quickly and the oxygen to be consumed more quickly. The oxygen slices demonstrate that in the beginning, the fire can draw oxygen from Unit 20 and 22, but after $57 \mathrm{~s}$, the fire only has access to the oxygen in Unit 20. By $130 \mathrm{~s}$, the fire has consumed enough oxygen to reduce the concentration below the $15 \%$ concentration necessary to allow combustion below $300{ }^{\circ} \mathrm{C}$ $\left(570^{\circ} \mathrm{F}\right)$ in Unit 20 . While FDS does allows some additional burning to occur at lower oxygen concentrations and higher temperatures, the unburned fuel is still accumulating in Unit 20. By $183 \mathrm{~s}$, the fire has dropped the oxygen concentrations to less than $6 \%$ and appears to have consumed all the oxygen in the rear of Unit 20 by 375 s. 


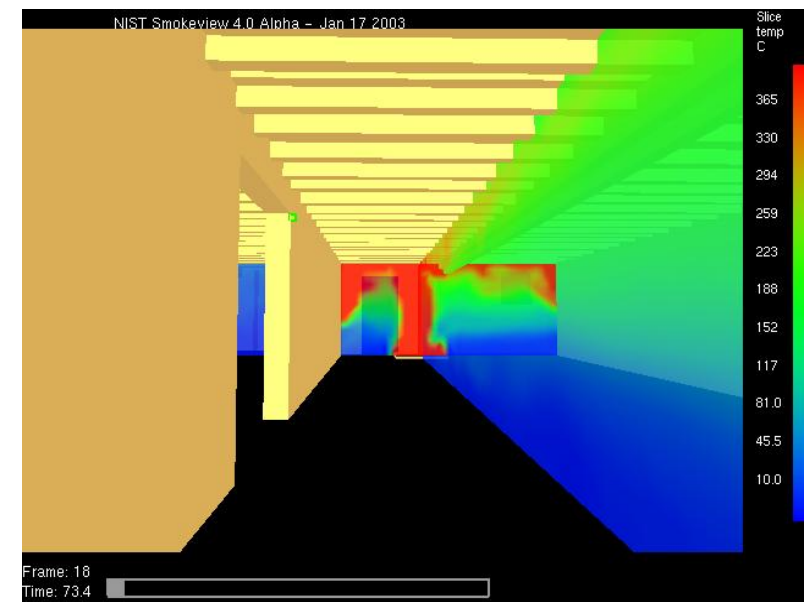

Figure 33. Temperature Profiles for an Initial $1000 \mathrm{~kW}$ Fire Source. Fire At Time $=73$ s. Fire Door is Open.

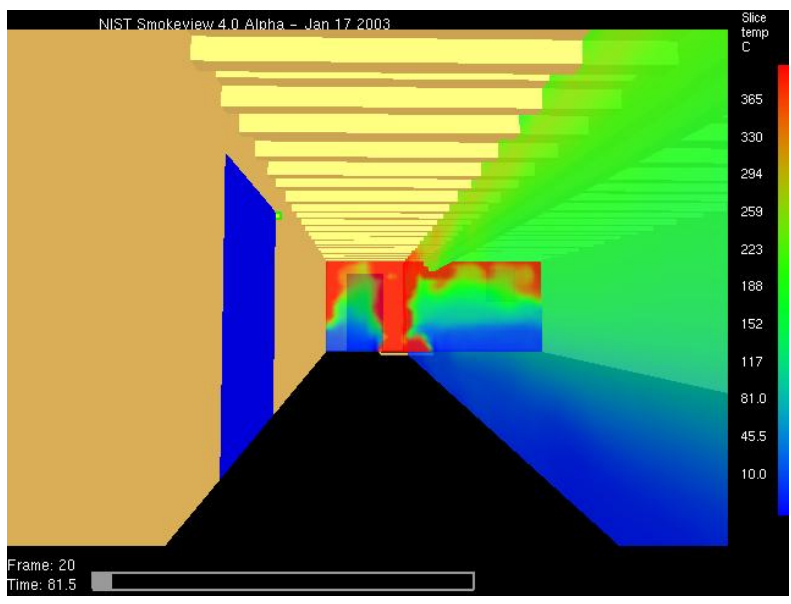

Figure 35. Temperature Profiles for an Initial $1000 \mathrm{~kW}$ Fire Source. Fire At Time $=81 \mathrm{~s}$. Fire Door Closed at $81 \mathrm{~s}$.

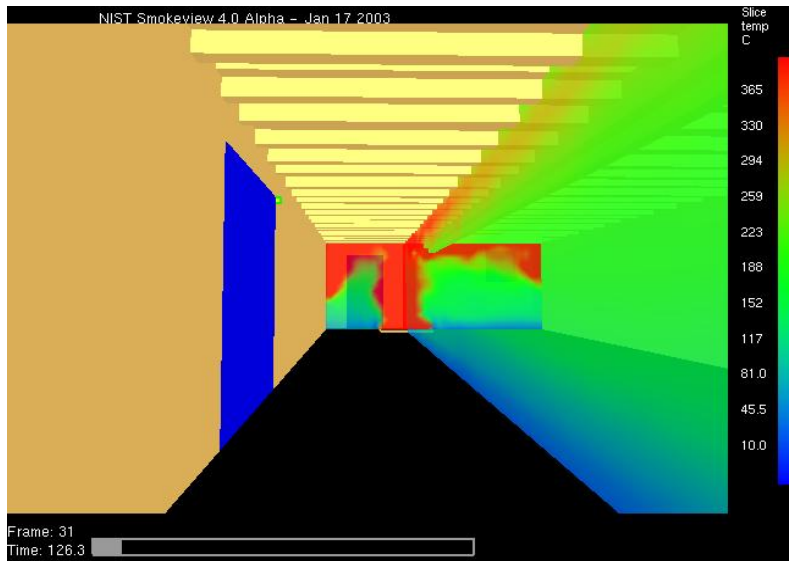

Figure 37. Temperature Profiles for an Initial 1000 kW Fire Source. Fire At Time $=126 \mathrm{~s}$. Fire Door Closed at $81 \mathrm{~s}$.

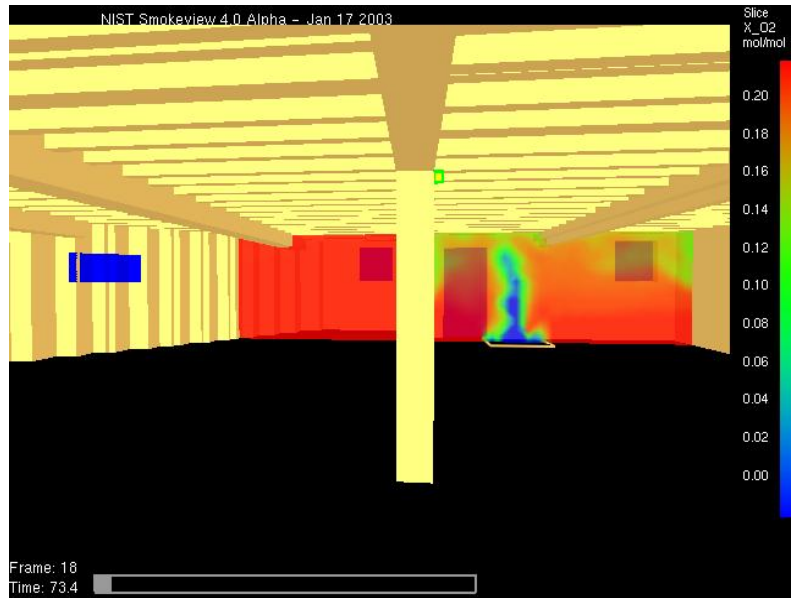

Figure 34. Oxygen Concentrations for an Initial $1000 \mathrm{~kW}$ Fire Source. Fire At Time $=73$ s. Fire Door is Open.

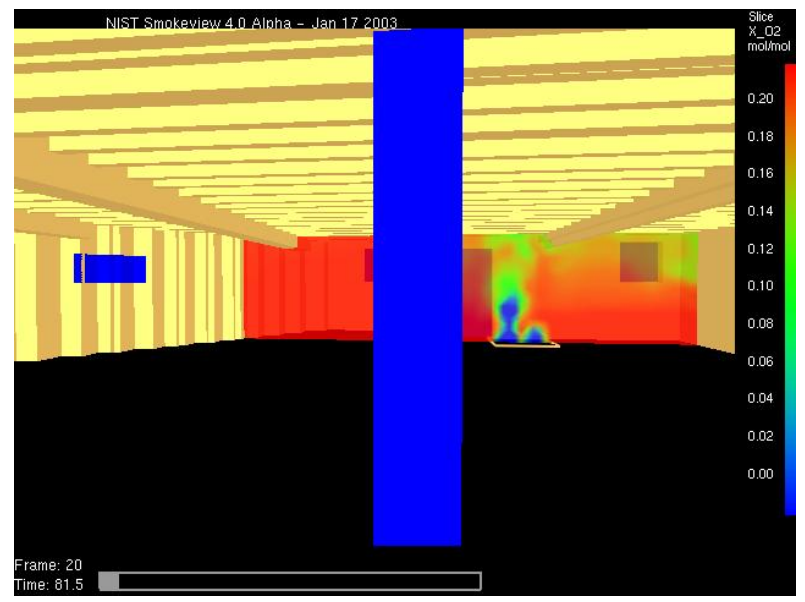

Figure 36. Oxygen Concentrations for an Initial $1000 \mathrm{~kW}$ Fire Source. Fire At Time $=81 \mathrm{~s}$. Fire Door Closed at $81 \mathrm{~s}$.

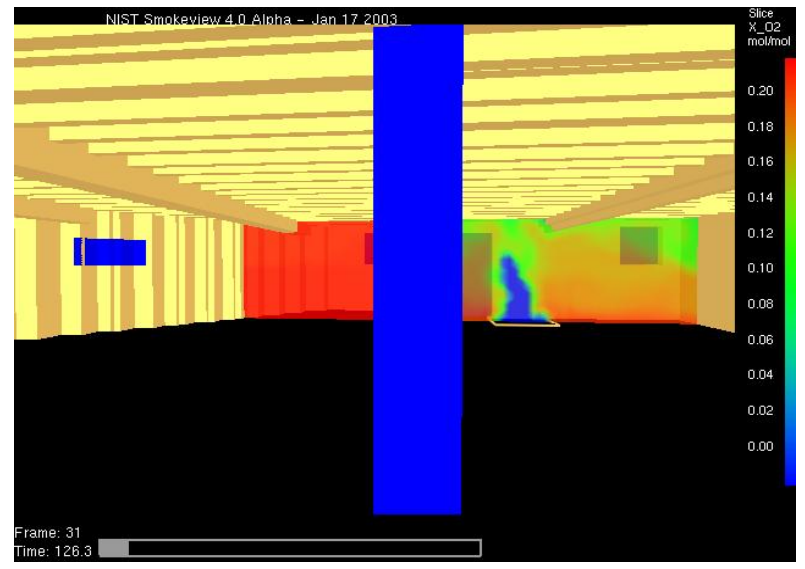

Figure 38. Oxygen Concentrations for an Initial $1000 \mathrm{~kW}$ Fire Source. Fire At Time $=126 \mathrm{~s}$. Fire Door Closed at $81 \mathrm{~s}$. 


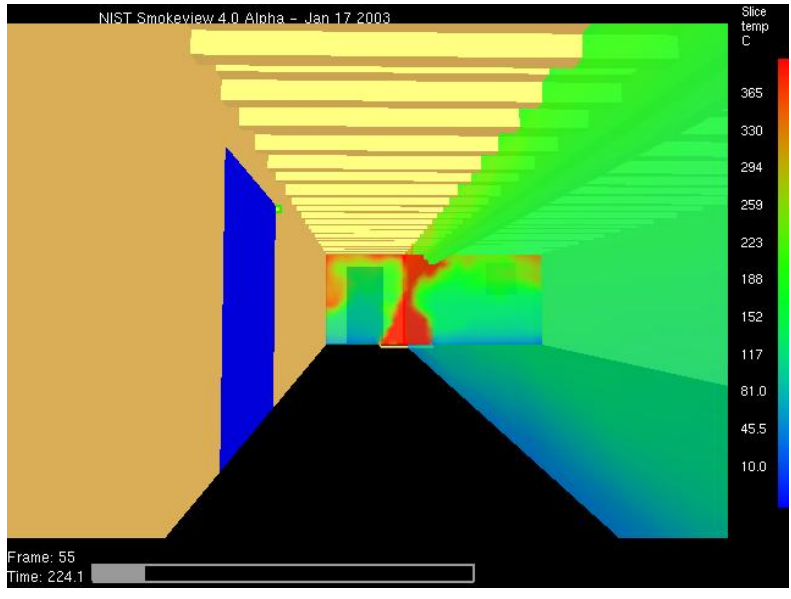

Figure 39. Temperature Profiles for an Initial $1000 \mathrm{~kW}$ Fire Source. Fire At Time $=224 \mathrm{~s}$. Fire Door Closed at $81 \mathrm{~s}$.

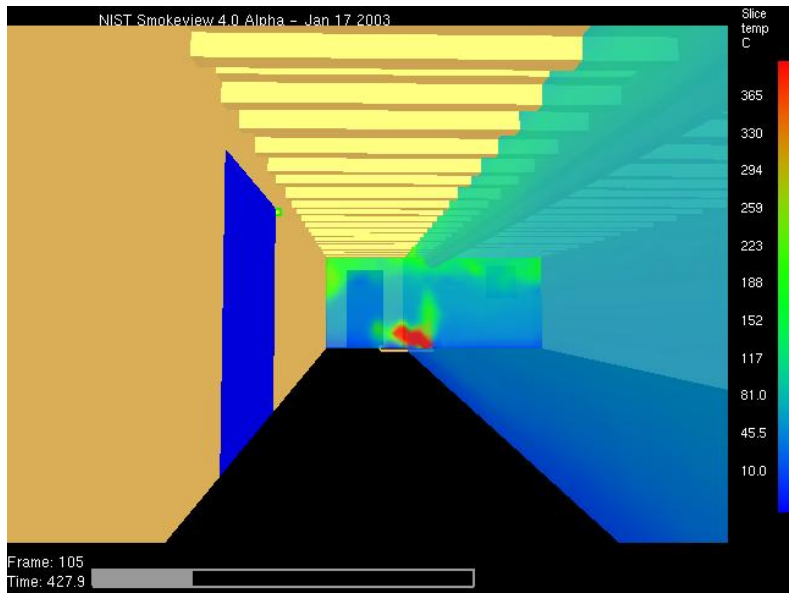

Figure 41. Temperature Profiles for an Initial $1000 \mathrm{~kW}$ Fire Source. Fire At Time $=428 \mathrm{~s}$. Fire Door Closed at $81 \mathrm{~s}$.

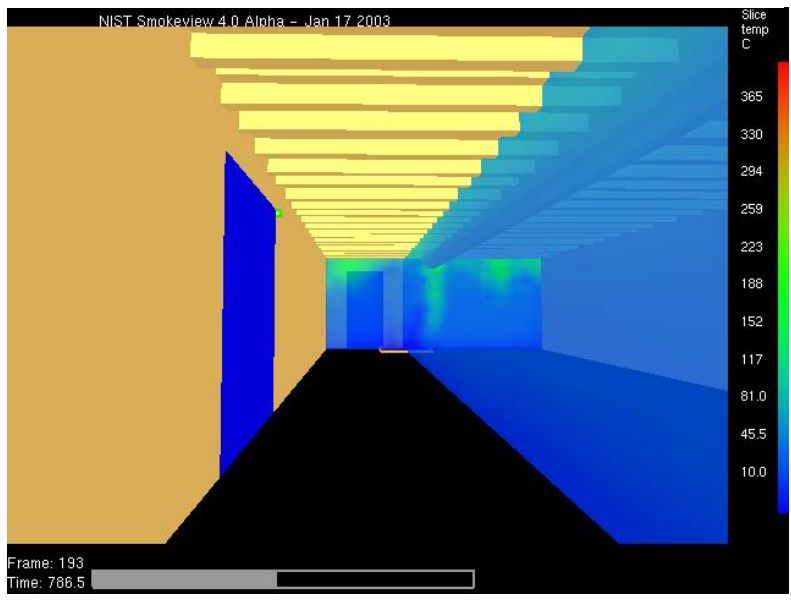

Figure 43. Temperature Profiles for an Initial $1000 \mathrm{~kW}$ Fire Source. Fire At Time $=767 \mathrm{~s}$. Fire Door Closed at $81 \mathrm{~s}$.

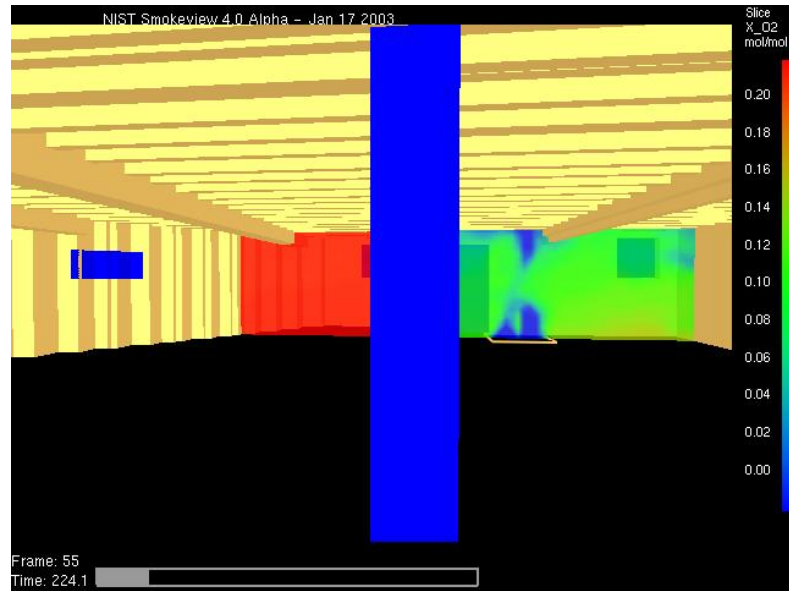

Figure 40. Oxygen Concentrations for an Initial $1000 \mathrm{~kW}$ Fire Source. Fire At Time $=224$ s. Fire Door Closed at $81 \mathrm{~s}$.

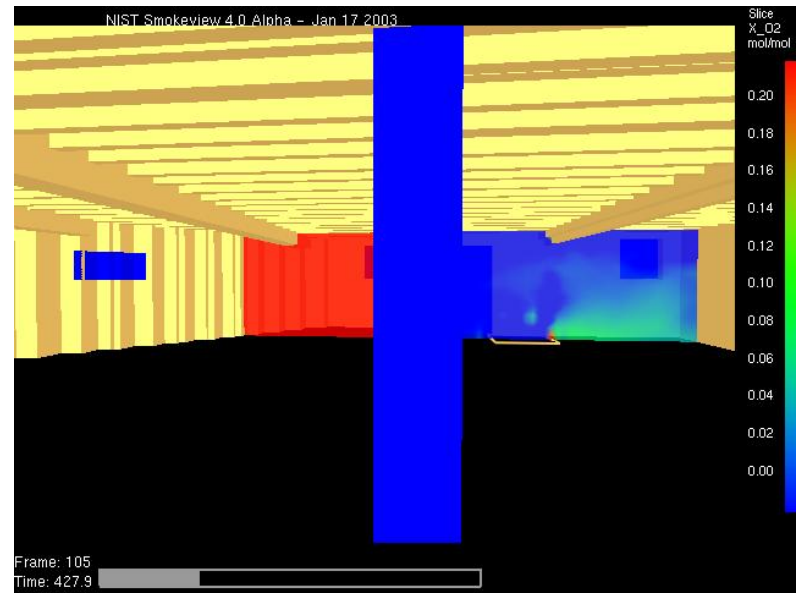

Figure 42. Oxygen Concentrations for an Initial $1000 \mathrm{~kW}$ Fire Source. Fire At Time $=428 \mathrm{~s}$. Fire Door Closed at $81 \mathrm{~s}$.

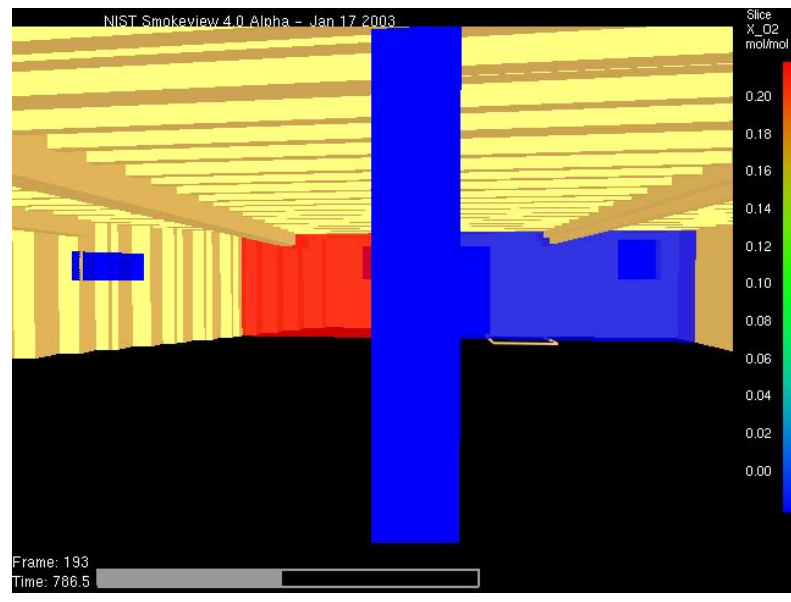

Figure 44. Oxygen Concentrations for an Initial $1000 \mathrm{~kW}$ Fire Source. Fire At Time $=767 \mathrm{~s}$. Fire Door Closed at $81 \mathrm{~s}$. 


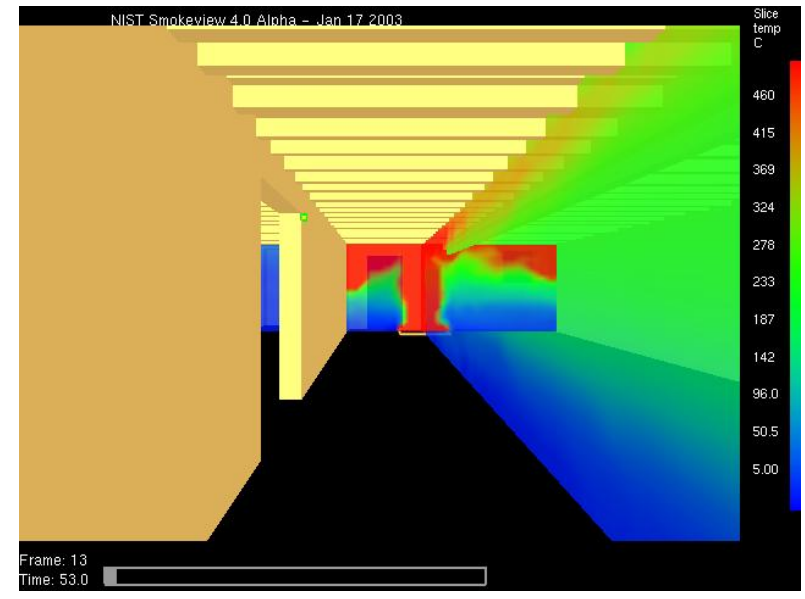

Figure 45. Temperature Profiles for an Initial 2000 kW Fire Source. Fire At Time $=53$ s. Fire Door is Open.

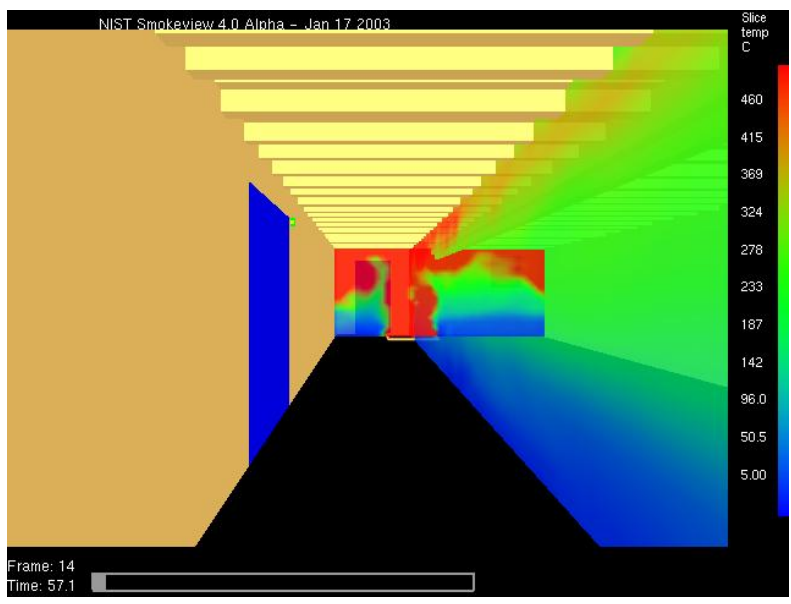

Figure 47. Temperature Profiles for an Initial 2000 kW Fire Source. Fire At Time $=57 \mathrm{~s}$. Fire Door Closed at $57 \mathrm{~s}$.

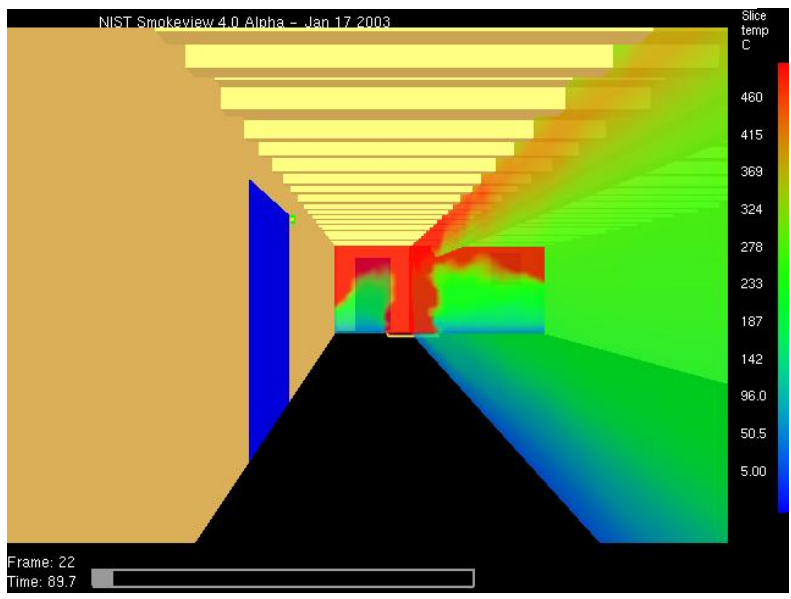

Figure 49. Temperature Profiles for an Initial $2000 \mathrm{~kW}$ Fire Source. Fire At Time $=90 \mathrm{~s}$. Fire Door Closed at $57 \mathrm{~s}$.

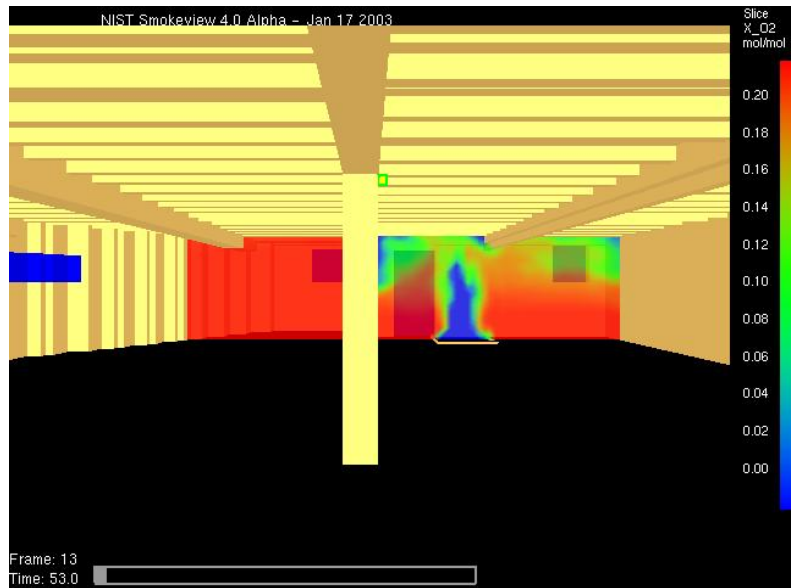

Figure 46. Oxygen Concentrations for an Initial 2000 kW Fire Source. Fire At Time $=53$ s. Fire Door is Open.

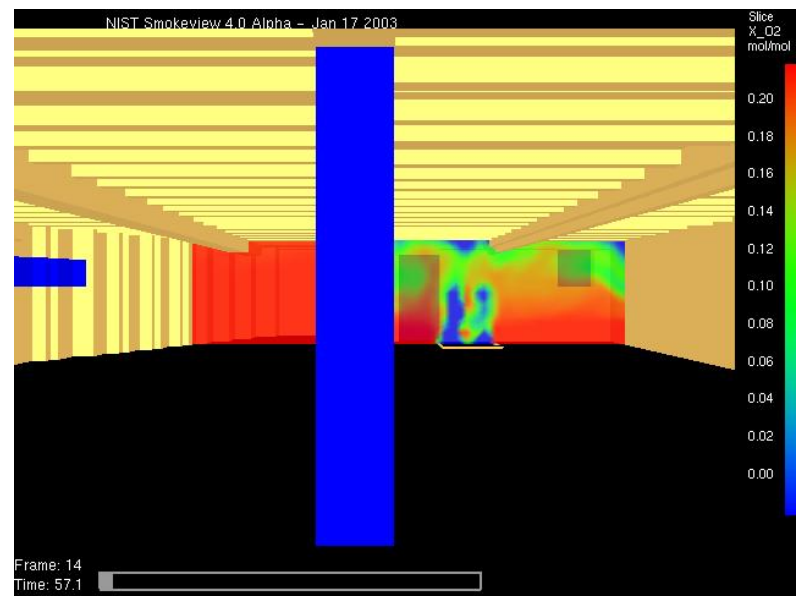

Figure 48. Oxygen Concentrations for an Initial $2000 \mathrm{~kW}$ Fire Source. Fire At Time $=57 \mathrm{~s}$. Fire Door Closed at $57 \mathrm{~s}$.

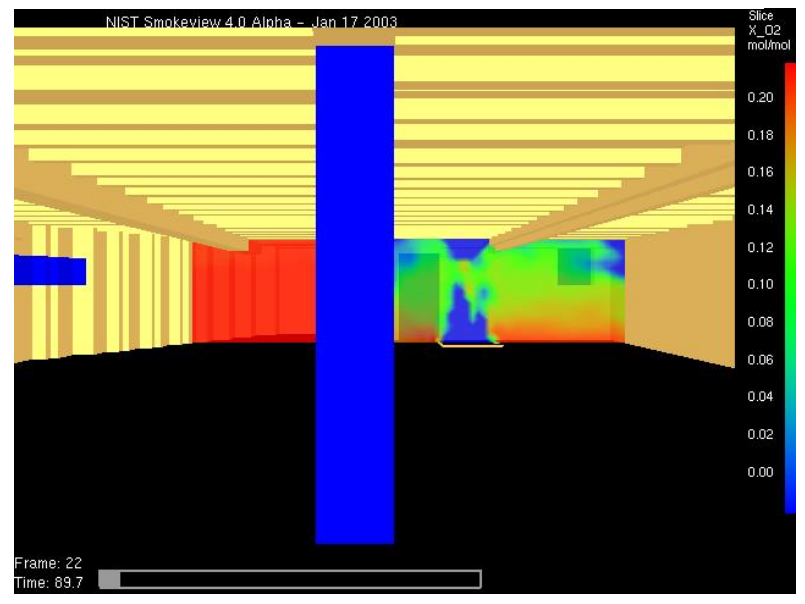

Figure 50. Oxygen Concentrations for an Initial $2000 \mathrm{~kW}$ Fire Source. Fire At Time $=90 \mathrm{~s}$. Fire Door Closed at $57 \mathrm{~s}$. 


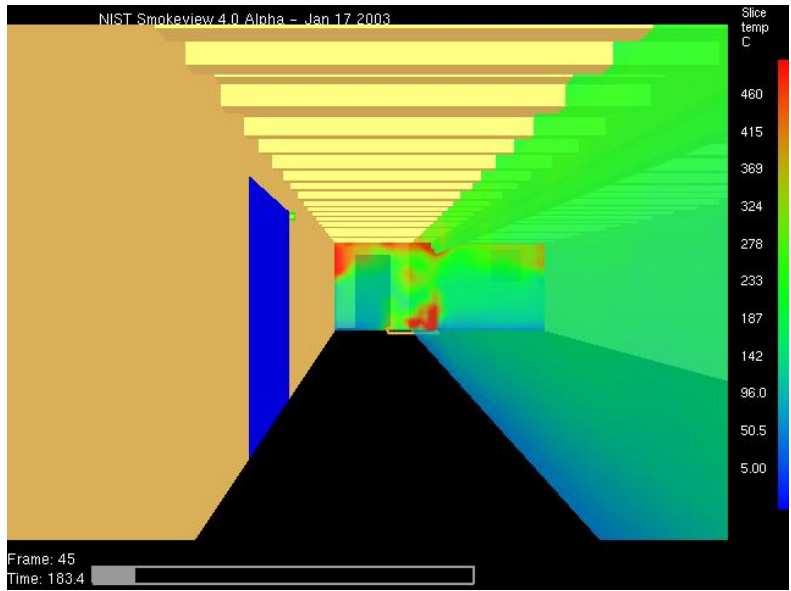

Figure 51. Temperature Profiles for an Initial $2000 \mathrm{~kW}$ Fire Source. Fire At Time $=183 \mathrm{~s}$. Fire Door Closed at $57 \mathrm{~s}$.

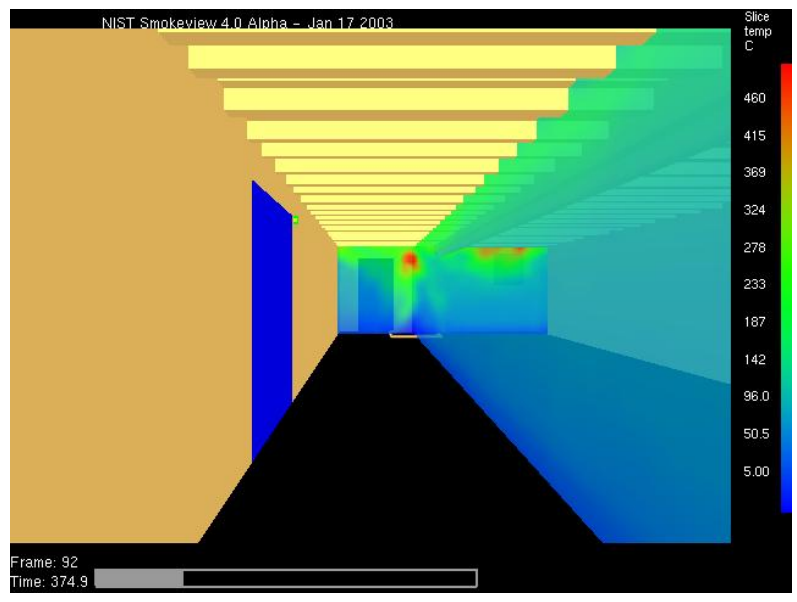

Figure 53. Temperature Profiles for an Initial $2000 \mathrm{~kW}$ Fire Source. Fire At Time $=375$ s. Fire Door Closed at $57 \mathrm{~s}$.

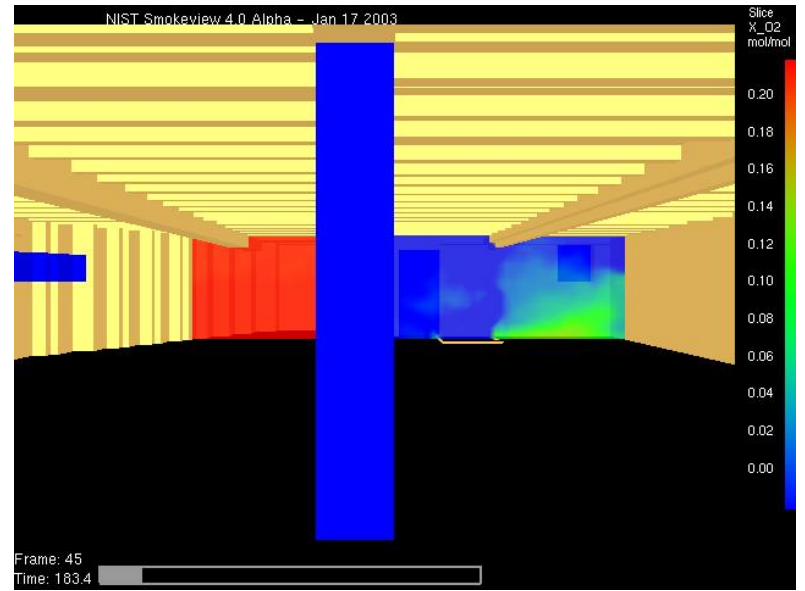

Figure 52. Oxygen Concentrations for an Initial $2000 \mathrm{~kW}$ Fire Source. Fire At Time $=183$ s. Fire Door Closed at 57 s.

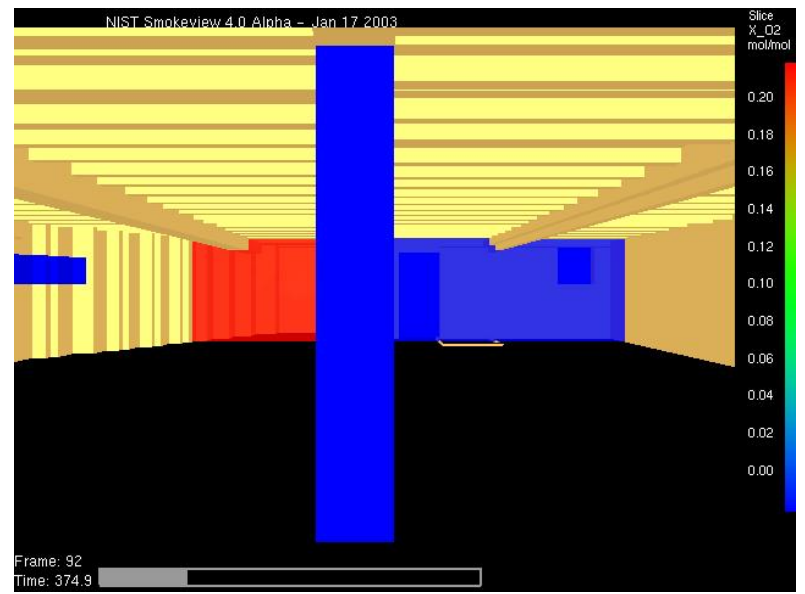

Figure 54. Oxygen Concentrations for an Initial $2000 \mathrm{~kW}$ Fire Source. Fire At Time $=375$ s. Fire Door Closed at 57 s.

\section{Fire Simulations With Fire Door Not Allowed to Close - 500 kW, 1000 kW, and $2000 \mathrm{~kW}$}

Figures 55 through 64 show the temperatures and oxygen concentrations in Unit 20 and 22 for an initial $500 \mathrm{~kW}$ fire source at time steps of $120 \mathrm{~s}, 128 \mathrm{~s}, 235 \mathrm{~s}, 566 \mathrm{~s}$, and $1088 \mathrm{~s}$.

Each gas temperature plot on the left is paired with its corresponding oxygen concentration plot on the right side. The fire door is open initially and the closing mechanism is disabled so that the fire door is not allowed to close. Even though the fire door could not close, the fusible link thermocouple temperatures were calculated and will be discussed later in this report. As can be observed from the temperature slices, the fire develops gas temperatures near the center of Unit 20 in excess of $200^{\circ} \mathrm{C}\left(392^{\circ} \mathrm{F}\right)$ in less than $120 \mathrm{~s}$. Since the fire door is not permitted to close, some of the hot gases flow from Unit 20 into Unit 22.

Fresh cool air from Unit 22 also flowed back to Unit 20 and provided dilution air as well as additional oxygen for the fire. As compared to the $500 \mathrm{~kW}$ fire (Figures 23 - 32) where 
the fire door closed at $126 \mathrm{~s}$, the gas temperatures in this case increase more quickly and appear to reach the higher peak values (note change in temperature corresponding to red color). By $1221 \mathrm{~s}$, the gas temperatures are not quite as uniform as in the closed door case, but still most of Unit 20 appears near $20^{\circ} \mathrm{C}\left(68^{\circ} \mathrm{F}\right)$. The oxygen slices demonstrate that in the beginning the fire can draw oxygen from Unit 20 and 22, and by 235 s, a significant amount of the oxygen near the rear of Unit 22 has been consumed by the fire. By $970 \mathrm{~s}$, the fire has consumed enough oxygen to reduce the concentration below the $15 \%$ concentration necessary to allow combustion below $300^{\circ} \mathrm{C}\left(570^{\circ} \mathrm{F}\right)$ in Unit 20 and 22 . While FDS does allows some additional burning to occur at lower oxygen concentrations and higher temperatures, the unburned fuel is still accumulating in Unit 20. After $1221 \mathrm{~s}$, the fire has dropped the oxygen concentrations to less than $10 \%$ in the rear of Unit 20 and Unit 22.

Figures 65 through 78 show the temperatures and oxygen concentrations in Unit 20 and 22 for an initial $1000 \mathrm{~kW}$ fire source at time steps of $74 \mathrm{~s}, 82 \mathrm{~s}, 128 \mathrm{~s}, 223 \mathrm{~s}, 429 \mathrm{~s}, 788 \mathrm{~s}$, and $1270 \mathrm{~s}$. The fire door is open initially and the closing mechanism is disabled so that the fire door is not allowed to close.

As can be observed from the temperature slices, the fire develops gas temperatures near the center of Unit 20 in excess of $200^{\circ} \mathrm{C}\left(392^{\circ} \mathrm{F}\right)$ in less than $120 \mathrm{~s}$. The flow of hot combustion gases from Unit 20 into Unit 22 and the stream of cool air from Unit 22 into Unit 20 is again apparent. As one would expect the gas temperatures appear to increase more quickly as compared to the $500 \mathrm{~kW}$ door open case. But as compared to the $1000 \mathrm{~kW}$ fire (Figures $33-44$ ) where the fire door closed at $81 \mathrm{~s}$, the gas temperatures in this case also increase more quickly and appear to reach the higher peak values (note change in temperature corresponding to red color). By $1270 \mathrm{~s}$, most of the gas temperatures in the rear of Unit 20 appear near $20^{\circ} \mathrm{C}\left(68^{\circ} \mathrm{F}\right)$. The oxygen slices demonstrate that the fire can draw oxygen from Unit 20 and 22, and by 429 s, a significant amount of the oxygen near the rear of Unit 22 has been consumed by the fire. By $550 \mathrm{~s}$, the fire has consumed enough oxygen to reduce the concentration below the $15 \%$ concentration necessary to allow combustion below $300^{\circ} \mathrm{C}\left(570{ }^{\circ} \mathrm{F}\right)$ in Unit 20 and 22 . While FDS does allows some additional burning to occur at lower oxygen concentrations and higher temperatures, the unburned fuel is still accumulating in Unit 20 and 22. After $1270 \mathrm{~s}$, the fire has dropped the oxygen concentrations to less than $10 \%$ in the rear of Unit 20 and Unit 22. As compared to the $1000 \mathrm{~kW}$ closed door case, the fire in this case does not lower the oxygen concentration as quickly, but this would be expected since the oxygen in both Unit 20 and 22 would be available to the fire. Also as one would expect when comparing the $500 \mathrm{~kW}$ and $1000 \mathrm{~kW}$ open door cases, the higher heat release rate fire was able to deplete the oxygen in the rear of both units more quickly than the smaller fire.

Figures 79 through 90 show the temperatures and oxygen concentrations in Unit 20 and 22 for an initial $2000 \mathrm{~kW}$ fire source at times of $54 \mathrm{~s}, 58 \mathrm{~s}, 87 \mathrm{~s}, 166 \mathrm{~s}, 375 \mathrm{~s}$, and $644 \mathrm{~s}$. The fire door is open initially and the closing mechanism is disabled so that the fire door is not allowed to close. 


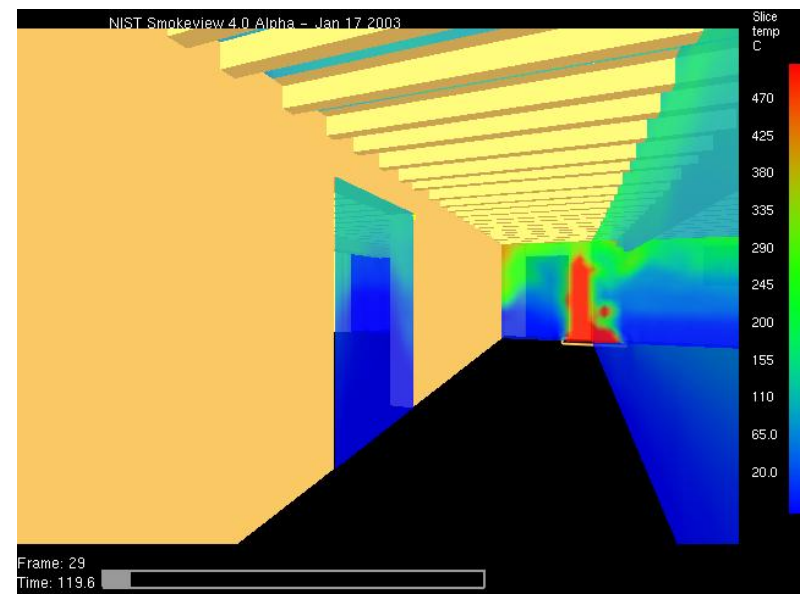

Figure 55. Temperature Profiles for an Initial $500 \mathrm{~kW}$ Fire Source. Fire At Time $=120 \mathrm{~s}$. Fire Door is Open and Closing Mechanism Disabled.

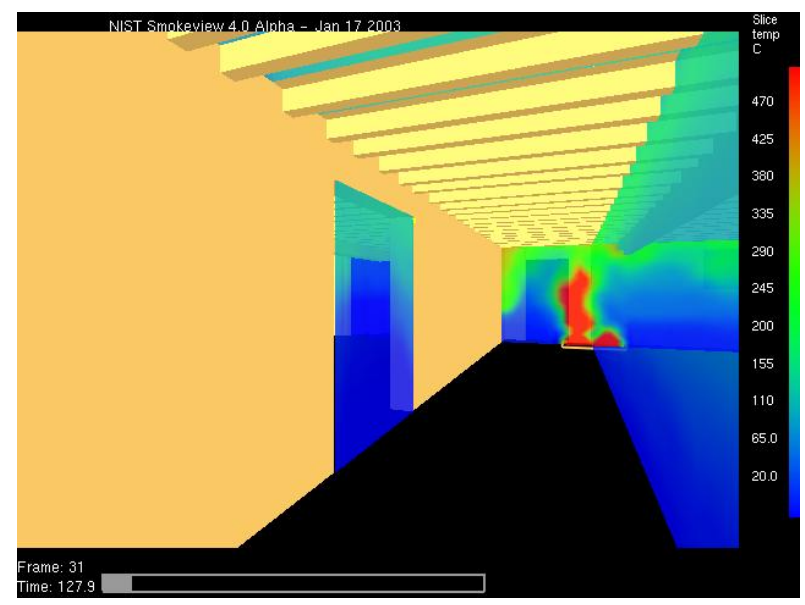

Figure 57. Temperature Profiles for an Initial $500 \mathrm{~kW}$ Fire Source. Fire At Time $=128 \mathrm{~s}$. Fire Door is Open and Closing Mechanism Disabled.

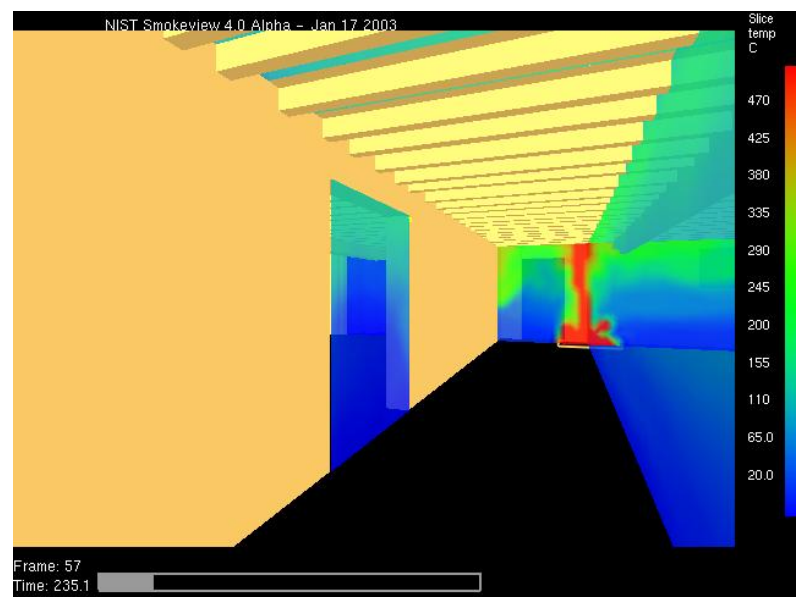

Figure 59. Temperature Profiles for an Initial $500 \mathrm{~kW}$ Fire Source. Fire At Time = $235 \mathrm{~s}$. Fire Door is Open and Closing Mechanism Disabled.

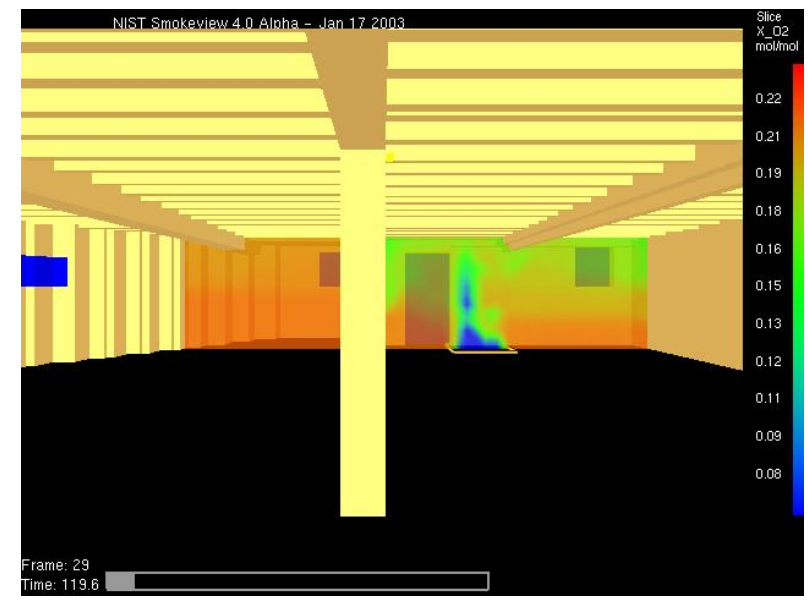

Figure 56. Oxygen Concentrations for an Initial $500 \mathrm{~kW}$ Fire Source. Fire At Time = 120 s. Fire Door is Open and Closing Mechanism Disabled.

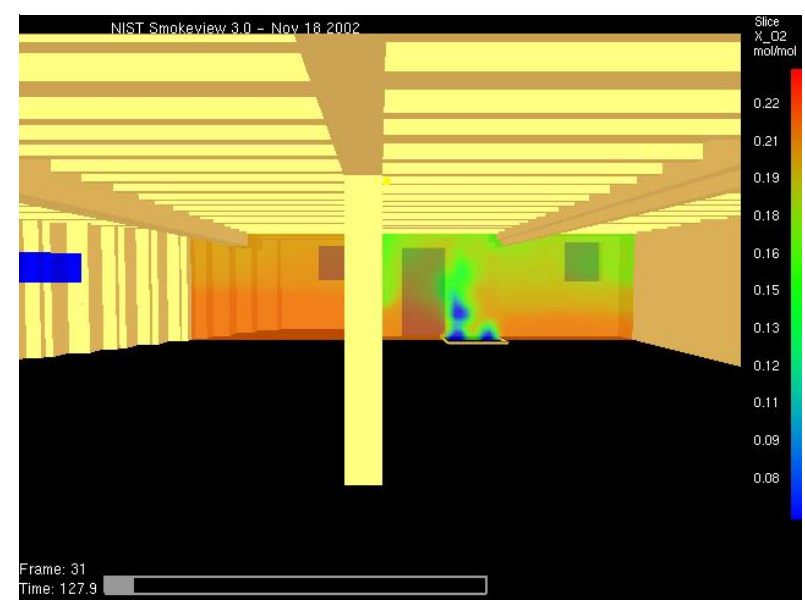

Figure 58. Oxygen Concentrations for an Initial $500 \mathrm{~kW}$ Fire Source. Fire At Time $=128 \mathrm{~s}$. Fire Door is Open and Closing Mechanism Disabled.

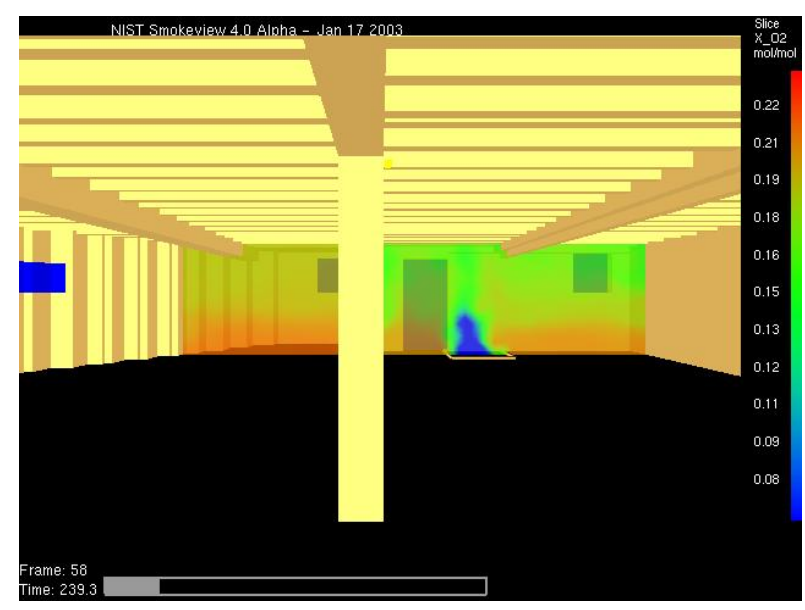

Figure 60. Oxygen Concentrations for an Initial $500 \mathrm{~kW}$ Fire Source. Fire At Time $=235 \mathrm{~s}$. Fire Door is Open and Closing Mechanism Disabled. 


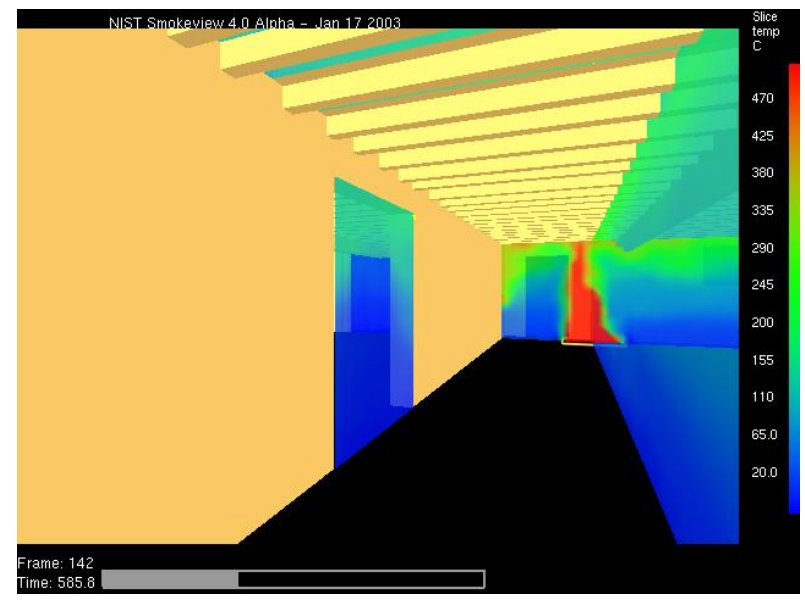

Figure 61. Temperature Profiles for an Initial $500 \mathrm{~kW}$ Fire Source. Fire At Time $=566 \mathrm{~s}$. Fire Door is Open and Closing Mechanism Disabled.

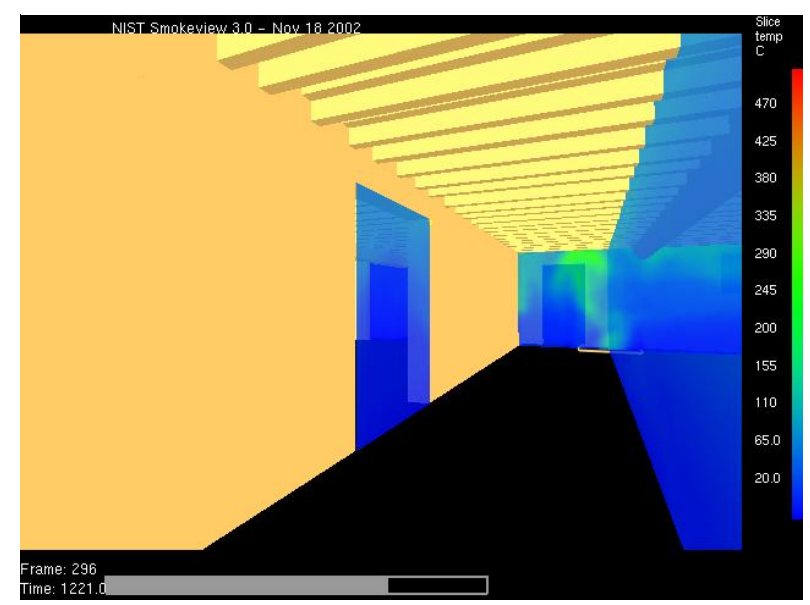

Figure 63. Temperature Profiles for an Initial $500 \mathrm{~kW}$ Fire Source. Fire At Time $=1221 \mathrm{~s}$. Fire Door Open and Closing Mechanism Disabled.

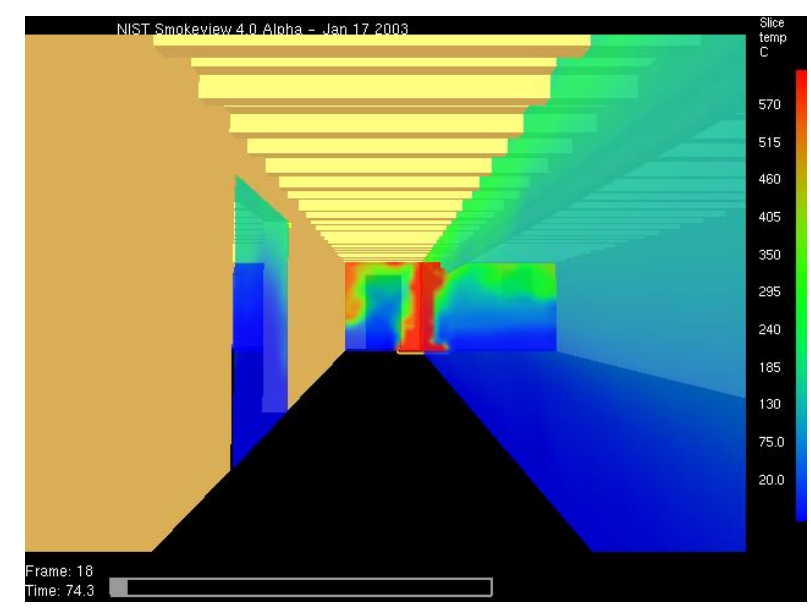

Figure 65. Temperature Profiles for an Initial $1000 \mathrm{~kW}$ Fire Source. Fire At Time $=74$ s. Fire Door Open.

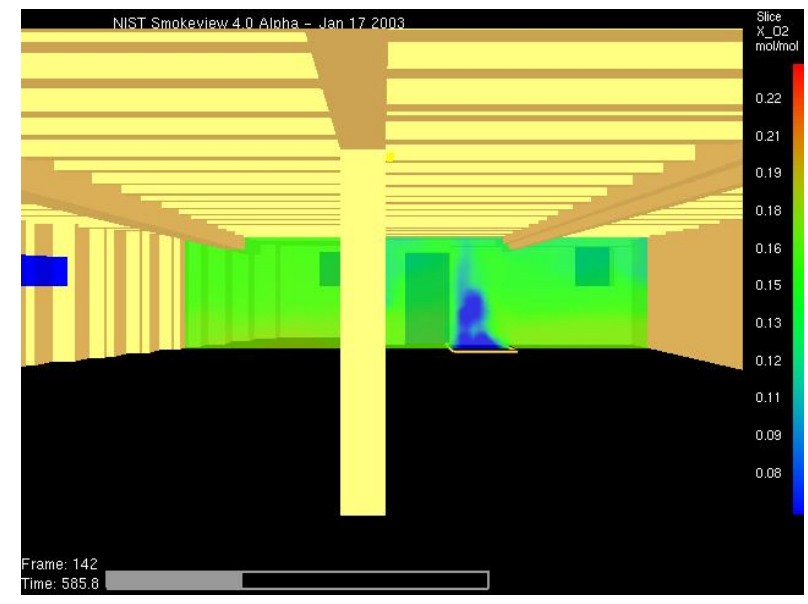

Figure 62. Oxygen Concentrations for an Initial 500 kW Fire Source. Fire At Time $=566$ s. Fire Door Open and Closing Mechanism Disabled.

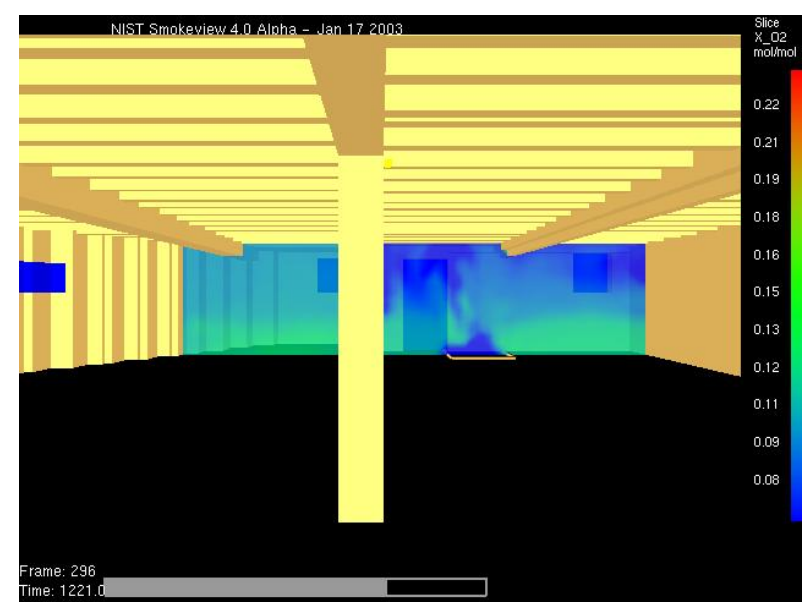

Figure 64. Oxygen Concentrations for an Initial $500 \mathrm{~kW}$ Fire Source. Fire At Time $=1221 \mathrm{~s}$. Fire Door is Open and Closing Mechanism Disabled.

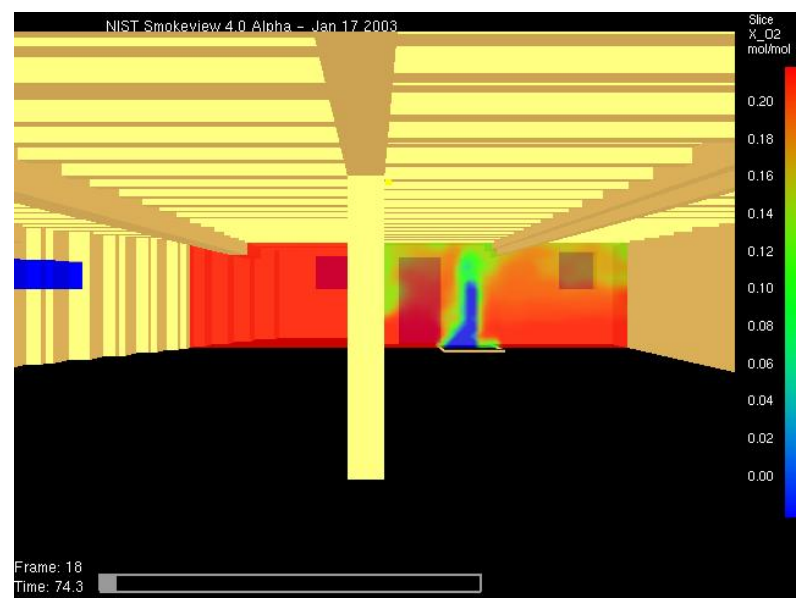

Figure 66. Oxygen Concentrations for an Initial 1000 kW Fire Source. Fire At Time $=74$ s. Fire Door is Open. 


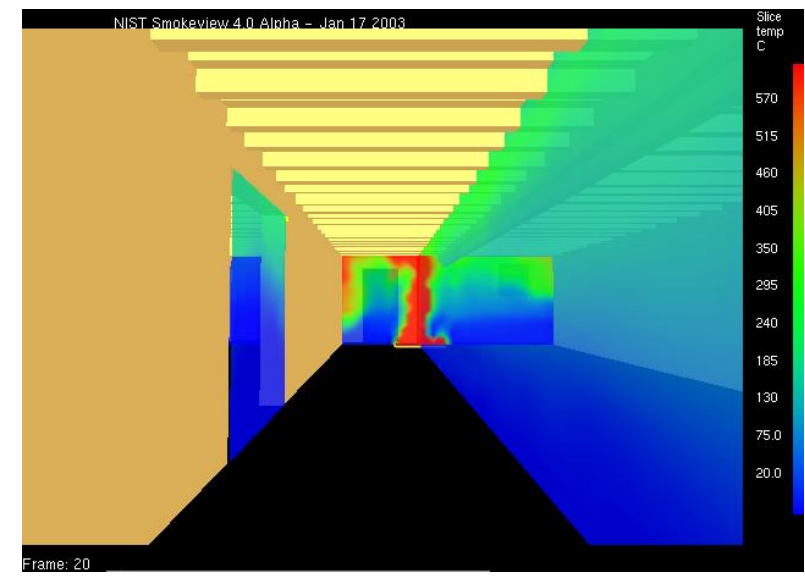

Figure 67. Temperature Profiles for an Initial $1000 \mathrm{~kW}$ Fire Source. Fire At Time $=82 \mathrm{~s}$. Fire Door Open and Closing Mechanism Disabled.

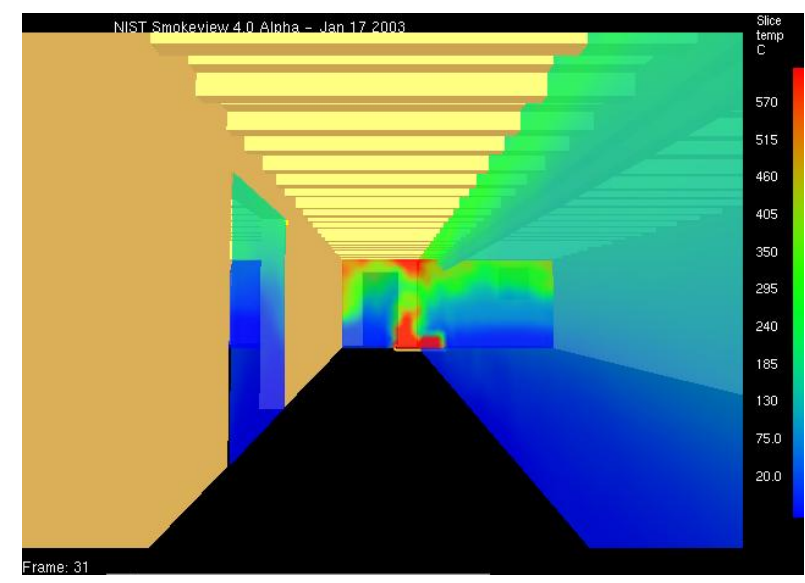

Figure 69. Temperature Profiles for an Initial $1000 \mathrm{~kW}$ Fire Source. Fire At Time $=128 \mathrm{~s}$. Fire Door Open and Closing Mechanism Disabled.

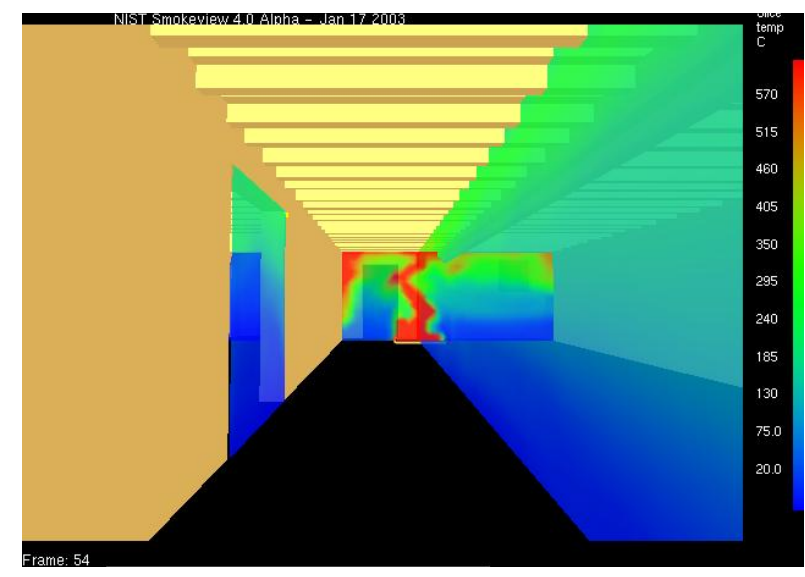

Figure 71. Temperature Profiles for an Initial $1000 \mathrm{~kW}$ Fire Source. Fire At Time $=223$ s. Fire Door Open and Closing Mechanism Disabled.

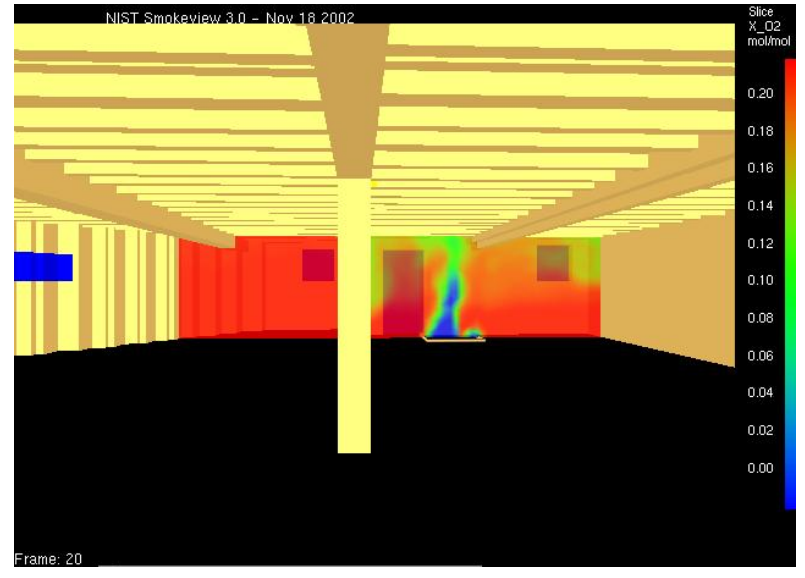

Figure 68. Oxygen Concentrations for an Initial 1000 kW Fire Source. Fire At Time $=82 \mathrm{~s}$. Fire Door is Open and Closing Mechanism Disabled.

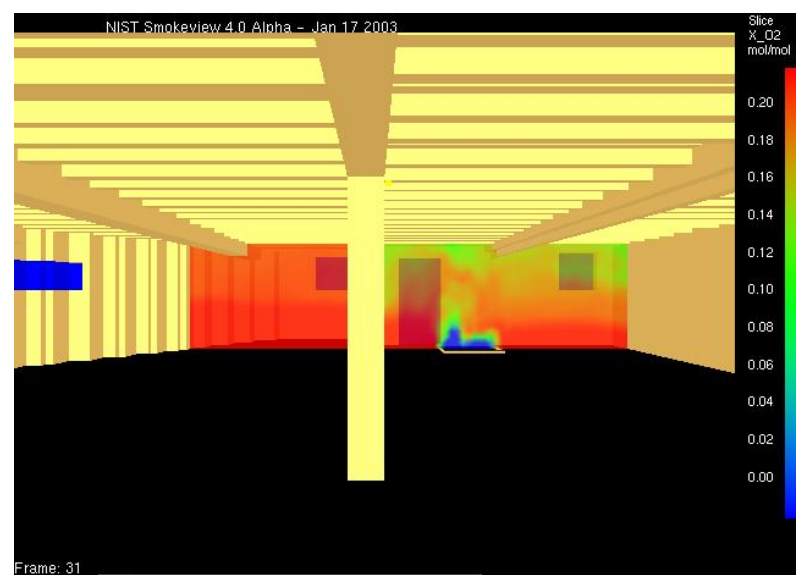

Figure 70. Oxygen Concentrations for an Initial $1000 \mathrm{~kW}$ Fire Source. Fire At Time = 128 s. Fire Door is Open and Closing Mechanism Disabled.

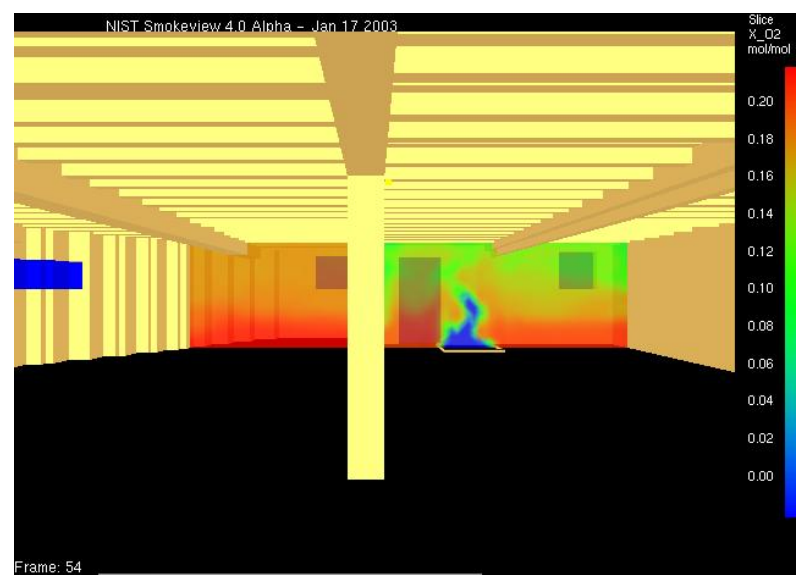

Figure 72. Oxygen Concentrations for an Initial 1000 kW Fire Source. Fire At Time $=223 \mathrm{~s}$. Fire Door is Open and Closing Mechanism Disabled. 


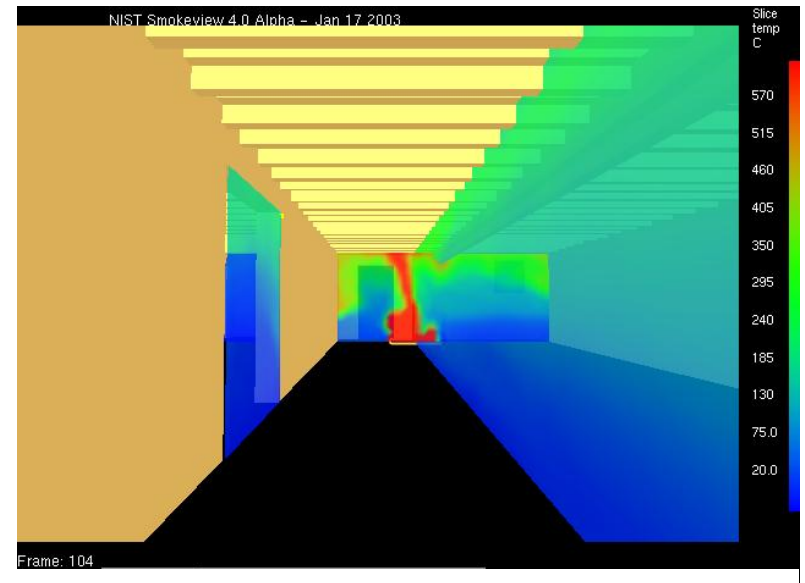

Figure 73. Temperature Profiles for an Initial 1000 kW Fire Source. Fire At Time $=429 \mathrm{~s}$. Fire Door Open and Closing Mechanism Disabled.

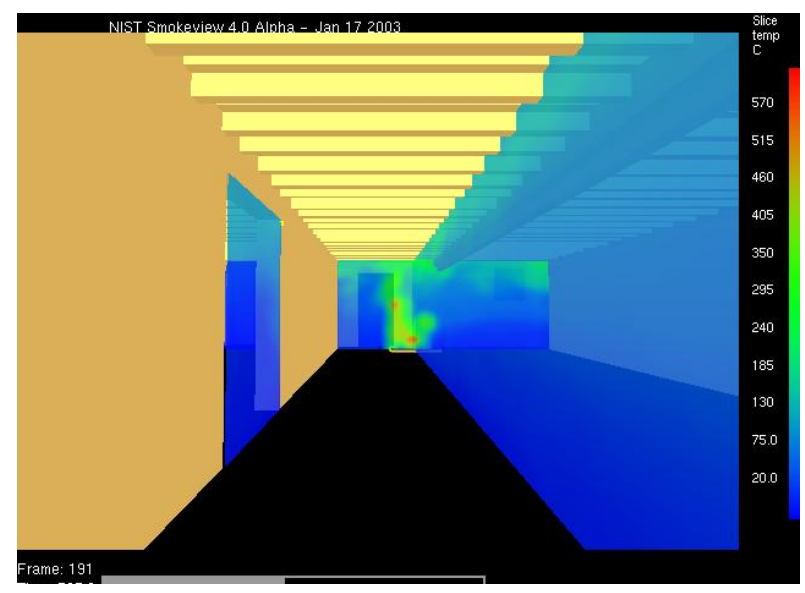

Figure 75. Temperature Profiles for an Initial $1000 \mathrm{~kW}$ Fire Source. Fire At Time $=788 \mathrm{~s}$. Fire Door Open and Closing Mechanism Disabled.

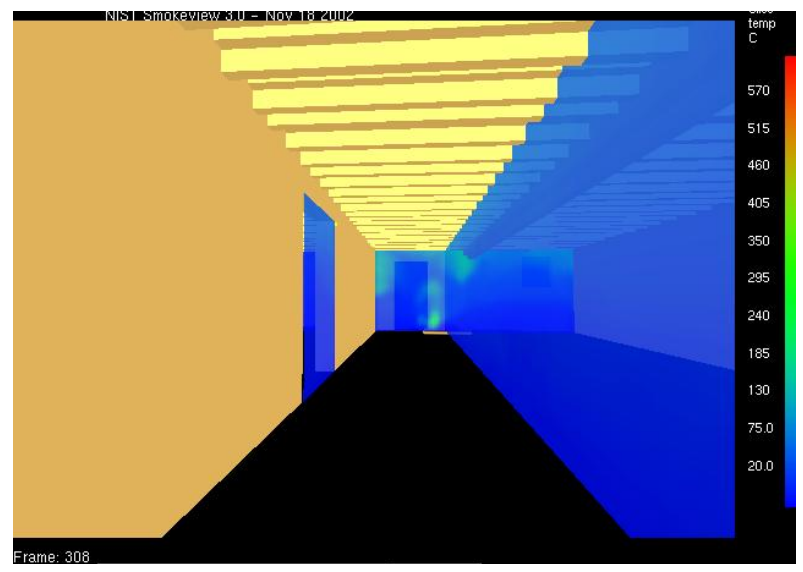

Figure 77. Temperature Profiles for an Initial $1000 \mathrm{~kW}$ Fire Source. Fire At Time $=1270 \mathrm{~s}$. Fire Door Open and Closing Mechanism n: 1 I

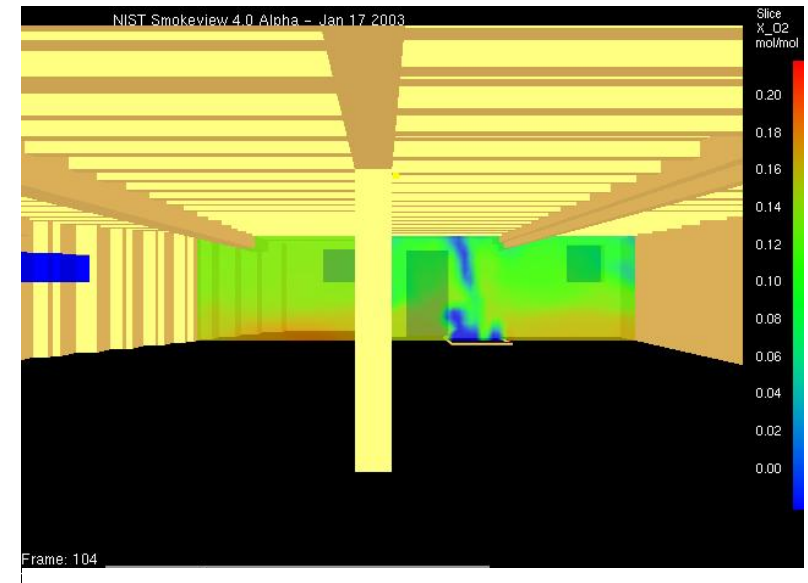

Figure 74. Oxygen Concentrations for an Initial $1000 \mathrm{~kW}$ Fire Source. Fire At Time $=429 \mathrm{~s}$. Fire Door is Open and Closing Mechanism Disabled.

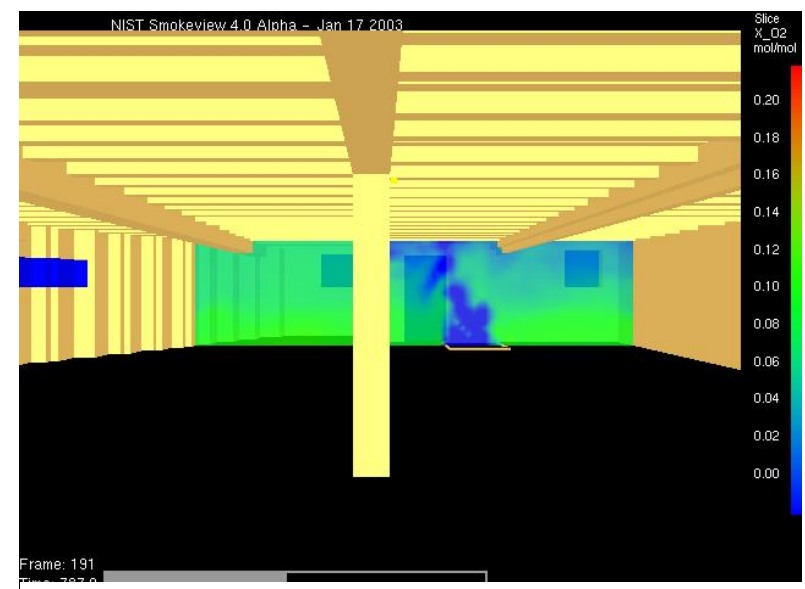

Figure 76. Oxygen Concentrations for an Initial $1000 \mathrm{~kW}$ Fire Source. Fire At Time $=788$ s. Fire Door is Open and Closing Mechanism Disabled.

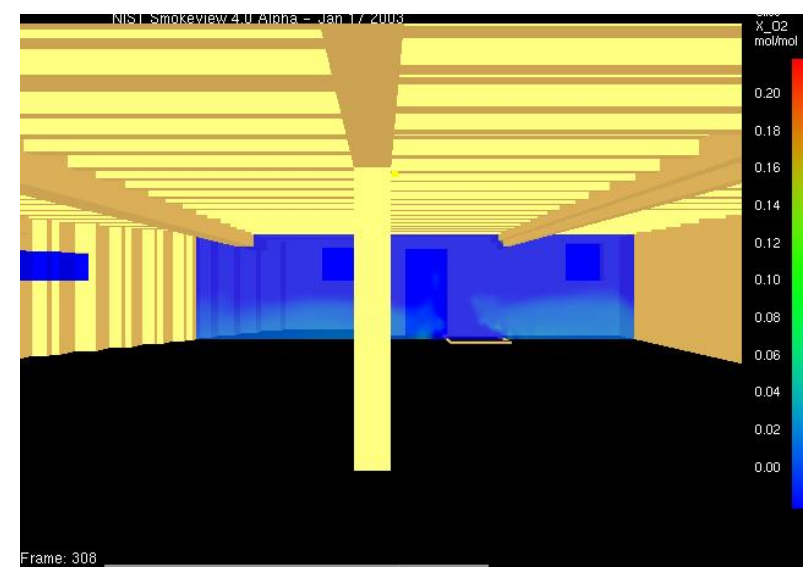

Figure 78. Oxygen Concentrations for an Initial $1000 \mathrm{~kW}$ Fire Source. Fire At Time $=1270$ s. Fire Door is Open and Closing Mechanism Disabled. 
As can be observed from the temperature slices, the fire develops gas temperatures near the center of Unit 20 in excess of $200^{\circ} \mathrm{C}\left(392^{\circ} \mathrm{F}\right)$ in less than $90 \mathrm{~s}$. The flow of hot combustion gases from Unit 20 into Unit 22 and the stream of cool air from Unit 22 into Unit 20 is again apparent. As one would expect the gas temperatures appear to increase more quickly as compared to the $500 \mathrm{~kW}$ and $1000 \mathrm{~kW}$ door open cases. But as compared to the $2000 \mathrm{~kW}$ fire (Figures 65 - 78) where the fire door closed at $57 \mathrm{~s}$, the gas temperatures in this case also increase more quickly and appear to reach the higher peak values (note change in temperature corresponding to red color). By $644 \mathrm{~s}$, most of the gas temperatures in the rear of Unit 20 appear less than $100{ }^{\circ} \mathrm{C}\left(212^{\circ} \mathrm{F}\right)$. The oxygen slices demonstrate that the fire can draw oxygen from Unit 20 and 22, and by 166 s, a significant amount of the oxygen near the rear of Unit 22 has been consumed by the fire. By $310 \mathrm{~s}$, the fire has consumed enough oxygen to reduce the concentration below the $15 \%$ concentration necessary to allow combustion below $300^{\circ} \mathrm{C}\left(570^{\circ} \mathrm{F}\right)$ in Unit 20 and 22. While FDS does allows some additional burning to occur at lower oxygen concentrations and higher temperatures, the unburned fuel is still accumulating in Unit 20 and 22. After $644 \mathrm{~s}$, the fire has dropped the oxygen concentrations to less than $12 \%$ in the rear of Unit 20 and Unit 22. As compared to the $2000 \mathrm{~kW}$ closed door case, the fire in this case does not lower the oxygen concentration as quickly, but this would be expected since the oxygen in both Unit 20 and 22 would be available to the fire. Also as one would expect when comparing the $500 \mathrm{~kW}, 1000 \mathrm{~kW}$, and $2000 \mathrm{~kW}$ open door cases, the highest heat release rate fire was able to deplete the oxygen in the rear of both units more quickly than either of the smaller fires.

As demonstrated by this limited set of gas temperature and oxygen concentration slice data, the $2000 \mathrm{~kW}$ fires overall resulted in higher temperatures and depleted the oxygen more quickly than either the $1000 \mathrm{~kW}$ or $500 \mathrm{~kW}$ fires. As compared to the closed door cases, the open door case fires required more time to deplete the oxygen in the rear of Unit 20, but the open door cases produced higher temperatures along the centerline of Unit 20.

\subsection{Fire Door Activation}

For each closed or open door cases, $500 \mathrm{~kW}, 1000 \mathrm{~kW}$, and $2000 \mathrm{~kW}$ fires, the gas temperature near the fusible link was monitored throughout each fire simulation. For each case, the gas temperature was plotted versus time for $1620 \mathrm{~s}$ of fire reconstruction. The gas temperatures are plotted in both Centigrade and Fahrenheit temperatures. For each of the closed door reconstructions, the time when the fire door closed is indicated on the data plot. The time that is indicated on each plot is when the fusible link released the door (after the link reached $74^{\circ} \mathrm{C}\left(165^{\circ} \mathrm{F}\right)$ and remained at that temperature for $\left.65 \mathrm{~s}\right)$. Once the link was softened or melted, the link would release the door and allow it to close. For each of the open door cases, the opening of the two basement windows in Unit 22 and the rear door in Unit 20 are indicated. For the open door reconstructions, the introduction of additional air via the rear door and basement windows causes the fire to begin to grow again. 


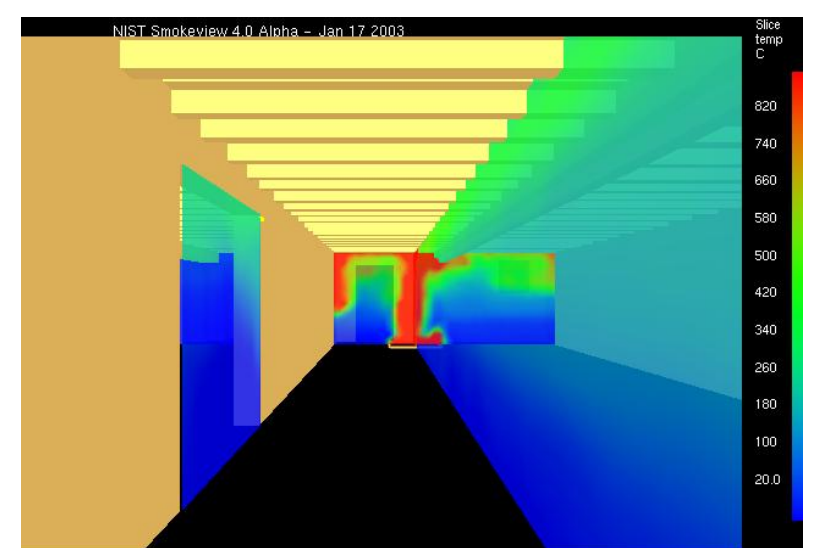

Figure 79. Temperature Profiles for an Initial $2000 \mathrm{~kW}$ Fire Source. Fire At Time $=54 \mathrm{~s}$. Fire Door Open.

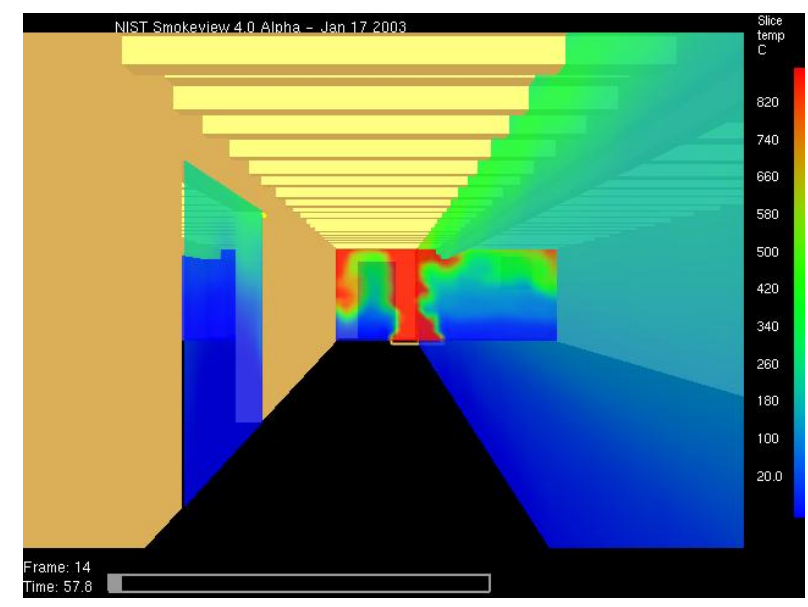

Figure 81. Temperature Profiles for an Initial $2000 \mathrm{~kW}$ Fire Source. Fire At Time $=58 \mathrm{~s}$. Fire Door Open and Closing Mechanism Disabled.

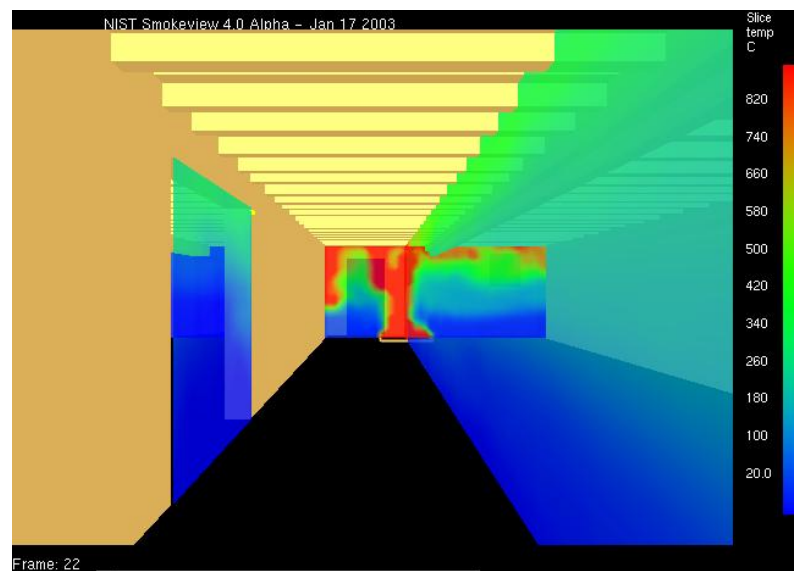

Figure 83. Temperature Profiles for an Initial $2000 \mathrm{~kW}$ Fire Source. Fire At Time $=87 \mathrm{~s}$. Fire Door Open and Closing Mechanism Disabled.

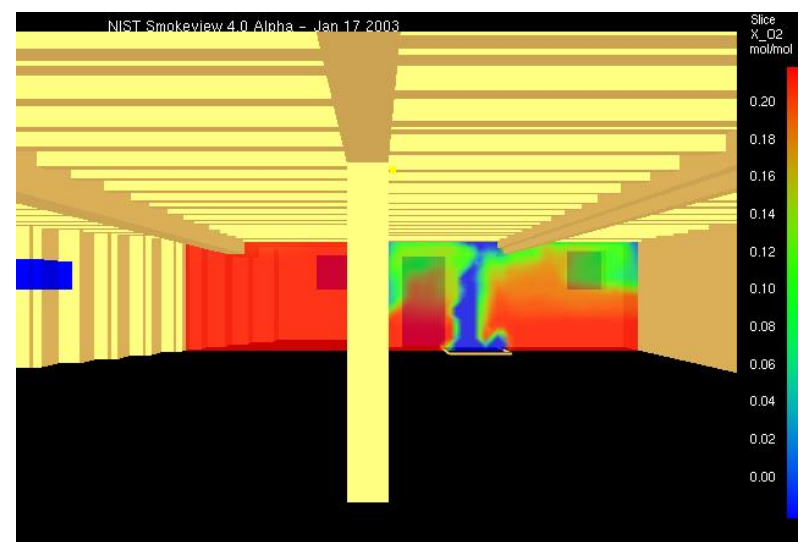

Figure 80. Oxygen Concentrations for an Initial 2000 kW Fire Source. Fire At Time $=54 \mathrm{~s}$. Fire Door is Onen.

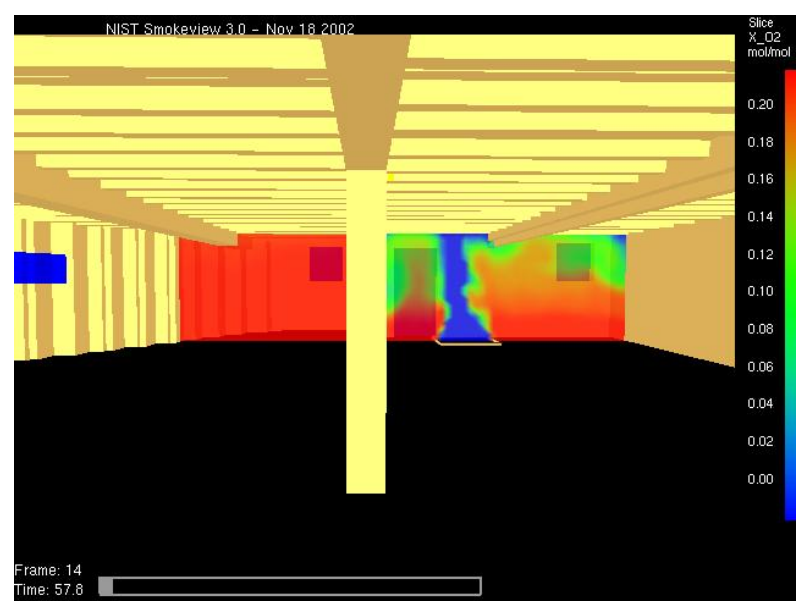

Figure 82. Oxygen Concentrations for an Initial 2000 kW Fire Source. Fire At Time $=58 \mathrm{~s}$. Fire Door is Open and Closing Mechanism Disabled.

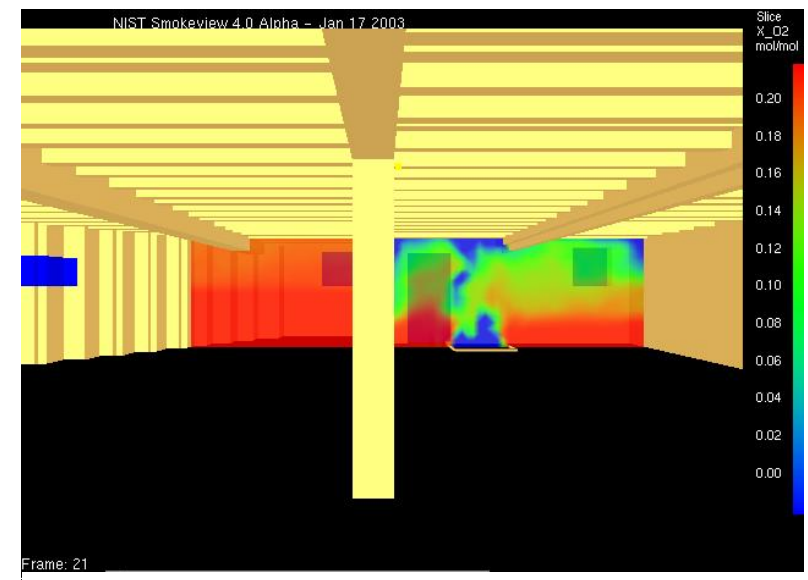

Figure 84. Oxygen Concentrations for an Initial $2000 \mathrm{~kW}$ Fire Source. Fire At Time = 87 s. Fire Door is Open and Closing Mechanism Disabled. 


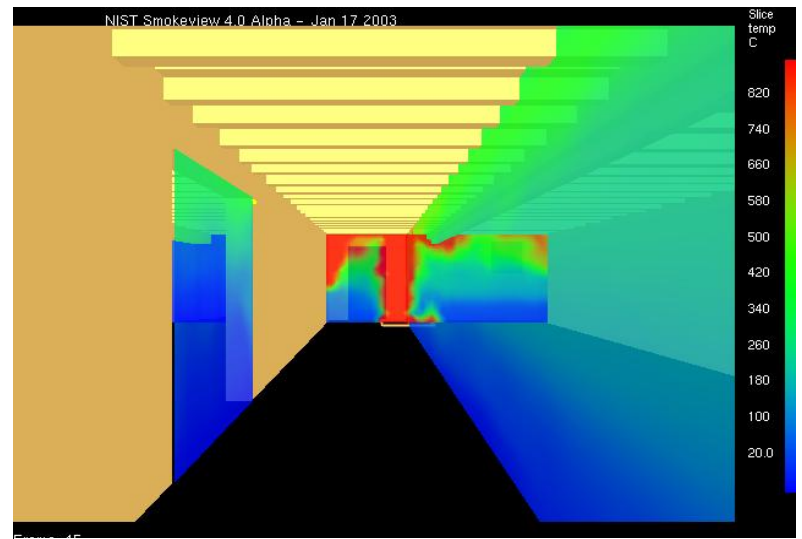

Figure 85. Temperature Profiles for an Initial 2000 kW Fire Source. Fire At Time $=166 \mathrm{~s}$. Fire Door Open and Closing Mechanism Disabled.

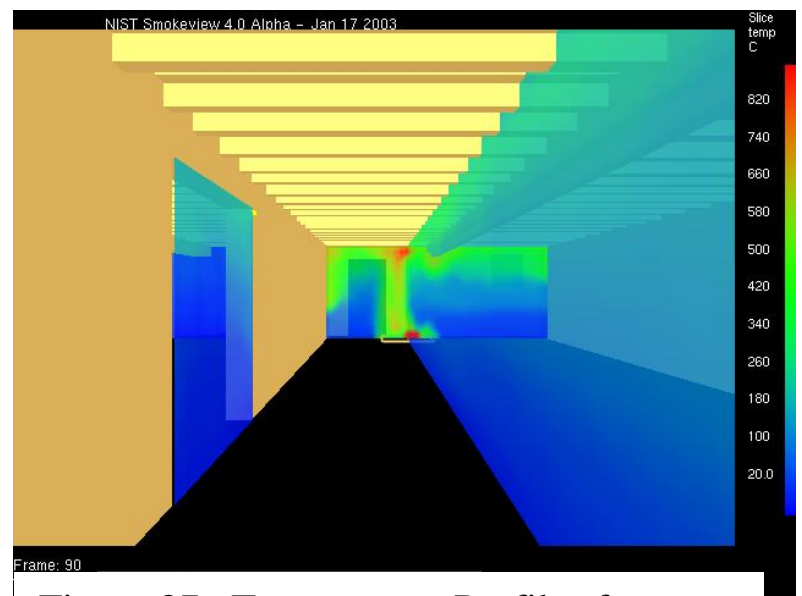

Figure 87. Temperature Profiles for an Initial 2000 kW Fire Source. Fire At Time $=375$ s. Fire Door Open and Closing Mechanism Disabled.

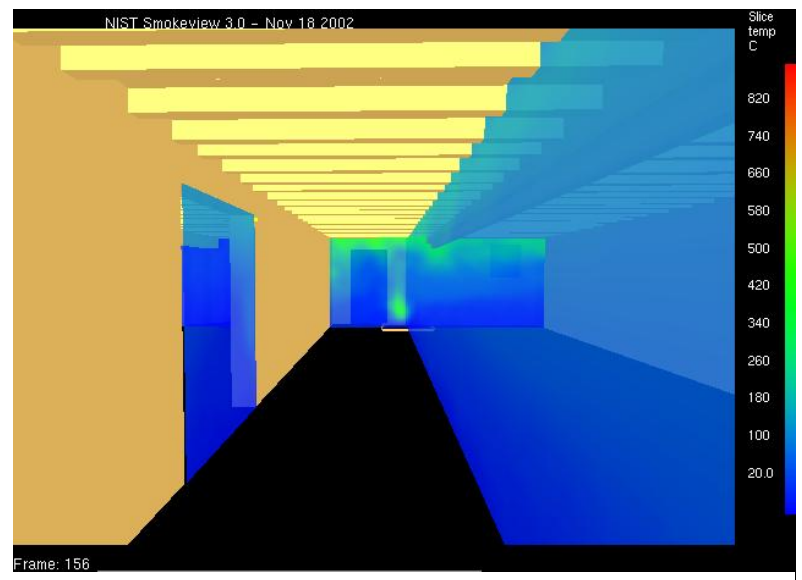

Figure 89. Temperature Profiles for an Initial $2000 \mathrm{~kW}$ Fire Source. Fire At Time $=644$ s. Fire Door Open and Closing Mechanism Disabled.

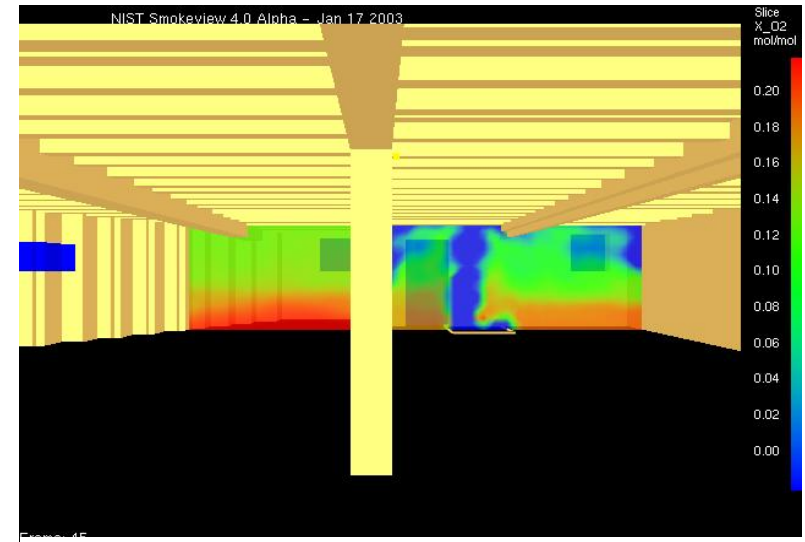

Figure 86. Oxygen Concentrations for an Initial $2000 \mathrm{~kW}$ Fire Source. Fire At Time $=166 \mathrm{~s}$. Fire Door is Open and Closing Mechanism Disabled.

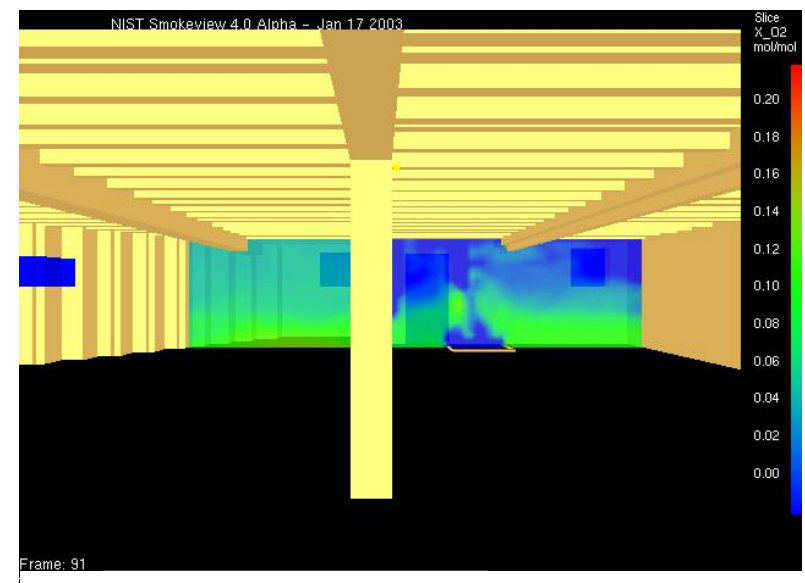

Figure 88. Oxygen Concentrations for an Initial $2000 \mathrm{~kW}$ Fire Source. Fire At Time = 375 s. Fire Door is Open and Closing Mechanism Disabled.

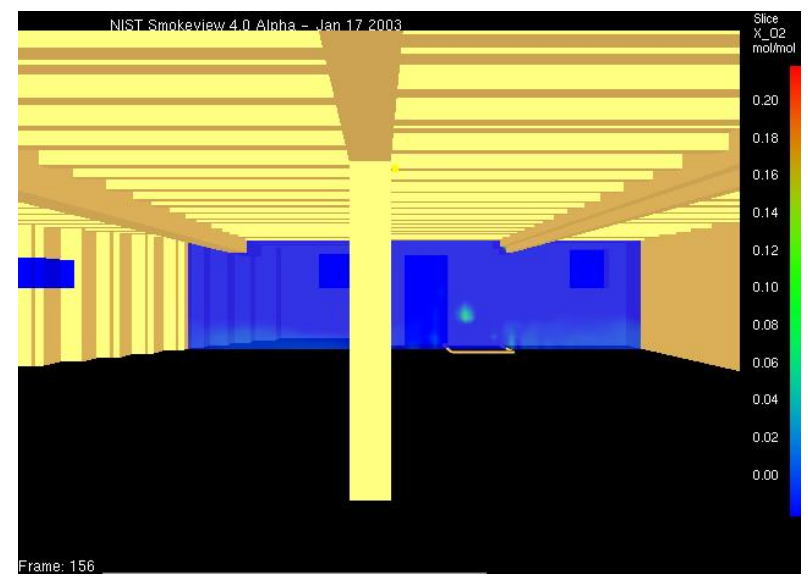

Figure 90. Oxygen Concentrations for an Initial $2000 \mathrm{~kW}$ Fire Source. Fire At Time $=644 \mathrm{~s}$. Fire Door is Open and Closing Mechanism Disabled. 
The gas temperatures for the initial $500 \mathrm{~kW}$ fire source closed door cases, Figure 91 (Centigrade Temperatures) and Figure 92 (Fahrenheit Temperatures) are plotted versus time. Peak temperatures were approximately $170^{\circ} \mathrm{C}\left(338^{\circ} \mathrm{F}\right)$. As the fire door closed at $126 \mathrm{~s}$ and the fire consumed most of the oxygen in Unit 20, the gas temperatures near the closed fire door decreased. The gas temperatures for the $500 \mathrm{~kW}$ open door cases, Figure 93 (Centigrade Temperatures) and Figure 94 (Fahrenheit Temperatures) are plotted versus time. Peak temperatures were slightly less than $170^{\circ} \mathrm{C}\left(338{ }^{\circ} \mathrm{F}\right)$. As the rear door and basement windows were opened, the additional air and oxygen allowed the fire to grow and produced an increase in gas temperatures after $1300 \mathrm{~s}$.

The gas temperatures for the initial $1000 \mathrm{~kW}$ fire source closed door cases, Figure 95 (Centigrade Temperatures) and Figure 96 (Fahrenheit Temperatures) are plotted versus time. Peak temperatures were approximately $240^{\circ} \mathrm{C}\left(464^{\circ} \mathrm{F}\right)$. As the fire door closed at $81 \mathrm{~s}$ and the fire consumed most of the oxygen in Unit 20, the gas temperatures near the closed fire door decreased. The gas temperatures for the $1000 \mathrm{~kW}$ open door cases, Figure 97 (Centigrade Temperatures) and Figure 98 (Fahrenheit Temperatures) are plotted versus time. Peak temperatures were significantly higher, $230{ }^{\circ} \mathrm{C}\left(446{ }^{\circ} \mathrm{F}\right)$ than in the closed door case. As the rear door and basement windows were opened, the additional air and oxygen allowed the fire to grow and produced a steep increase in gas temperatures after $1300 \mathrm{~s}$ than in the $500 \mathrm{~kW}$ fire case.

The gas temperatures for the $2000 \mathrm{~kW}$ closed door cases, Figure 99 (Centigrade Temperatures) and Figure 100 (Fahrenheit Temperatures) are plotted versus time. Peak temperatures were approximately $340{ }^{\circ} \mathrm{C}\left(644^{\circ} \mathrm{F}\right)$. As the fire door closed at $57 \mathrm{~s}$ and the fire consumed most of the oxygen in Unit 20, the gas temperatures near the closed fire door decreased. The gas temperatures for the $2000 \mathrm{~kW}$ open door cases, Figure 101 (Centigrade Temperatures) and Figure 102 (Fahrenheit Temperatures) are plotted versus time. Peak temperatures were similar, $359^{\circ} \mathrm{C}\left(678{ }^{\circ} \mathrm{F}\right)$ to the closed door case. As the rear door and basement windows were opened, the additional air and oxygen allowed the fire to grow and produced a steep increase in gas temperatures after $1300 \mathrm{~s}$ than in the $500 \mathrm{~kW}$ or $1000 \mathrm{~kW}$ fire cases.

Overall, this limited set of temperatures near the top of the fire door indicate that the higher heat release fires, especially the $2000 \mathrm{~kW}$ case, produced significantly higher gas temperatures than the lower heat release fires. The temperature peak was narrower for the closed door cases as compared to the broader peaks of the open door reconstructions. As the rear door in Unit 20 and the two windows in Unit 22 were opened after 1300 s, the gases temperatures increased in each of the open door cases.

In the basements of Unit 20 and 22, as each fire grew, the oxygen concentration dropped below concentrations which would allow combustion to occur. FDS would not allow burning or combustion to occur in the cells where the oxygen concentration dropped to lower concentrations. Fire scenarios where the oxygen has decreased to a level insufficient to support burning are termed "ventilation limited". Each of the fires in this study consumed sufficient oxygen to reduce the burning rate or become ventilation limited. 


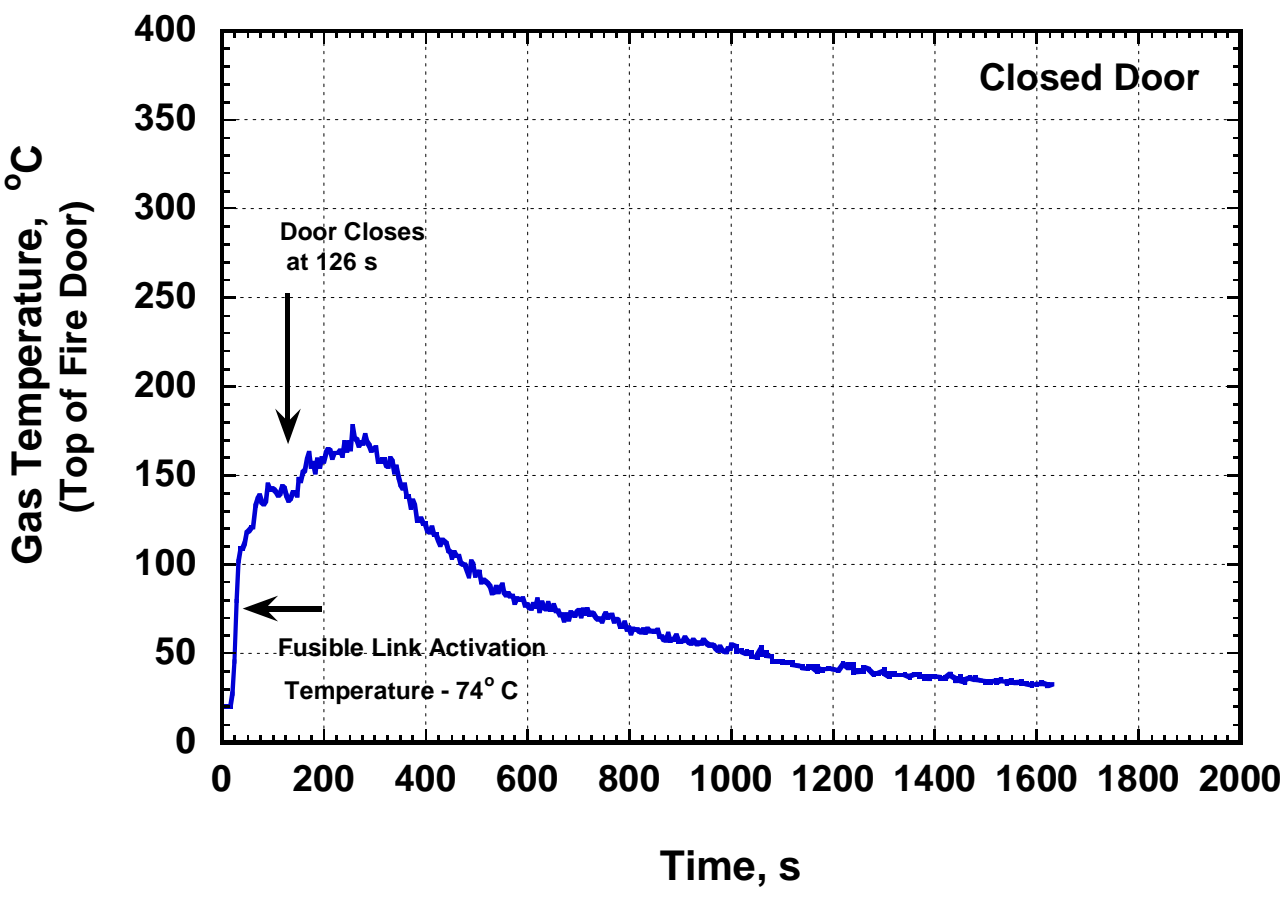

Figure 91. Temperatures (Centigrade) versus Time for Combustion Gases Near the Fusible Link on the Fire Door. For a Fire with an Initial 500 kW Heat Release Rate, the Fire Door Closed at 126 s.

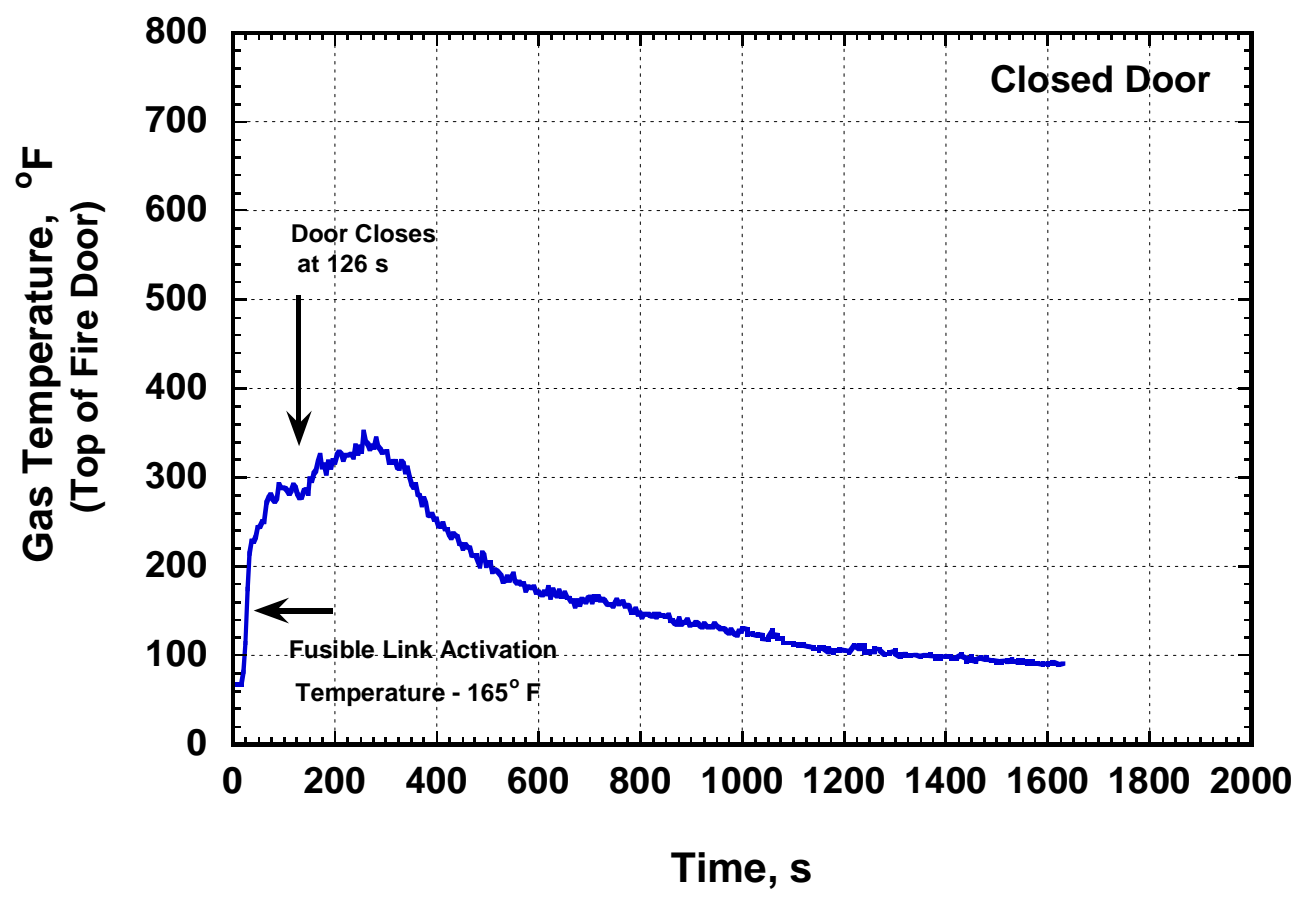

Figure 92. Temperatures (Fahrenheit) versus Time for Combustion Gases Near the Fusible Link on the Fire Door. For a Fire with an Initial 500 kW Heat Release Rate, the Fire Door Closed at 126 s. 


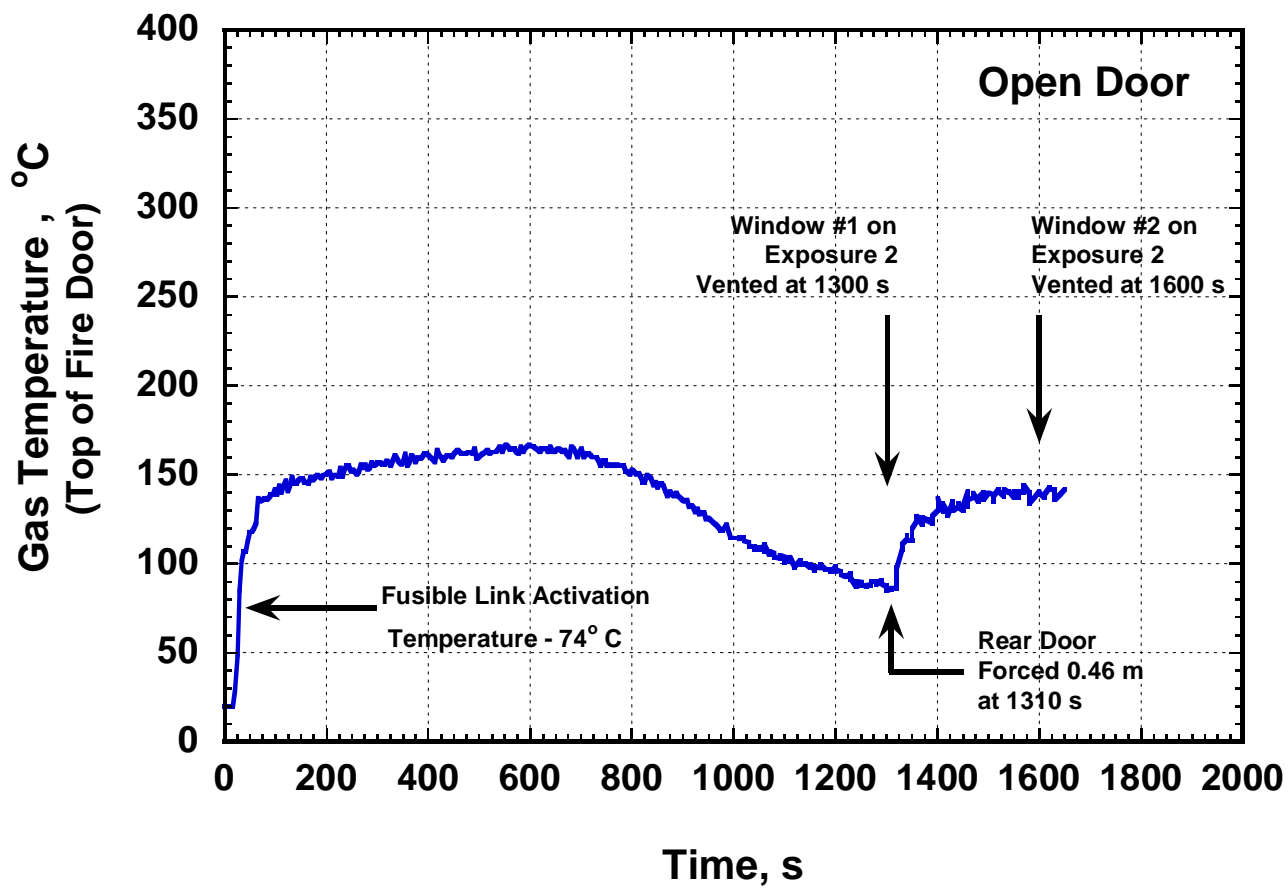

Figure 93. Temperatures (Centigrade) versus Time for Combustion Gases Near the Fusible Link on the Fire Door. For a Fire with an Initial 500 kW Heat Release Rate, the Fire Door Closing Mechanism Was Disabled.

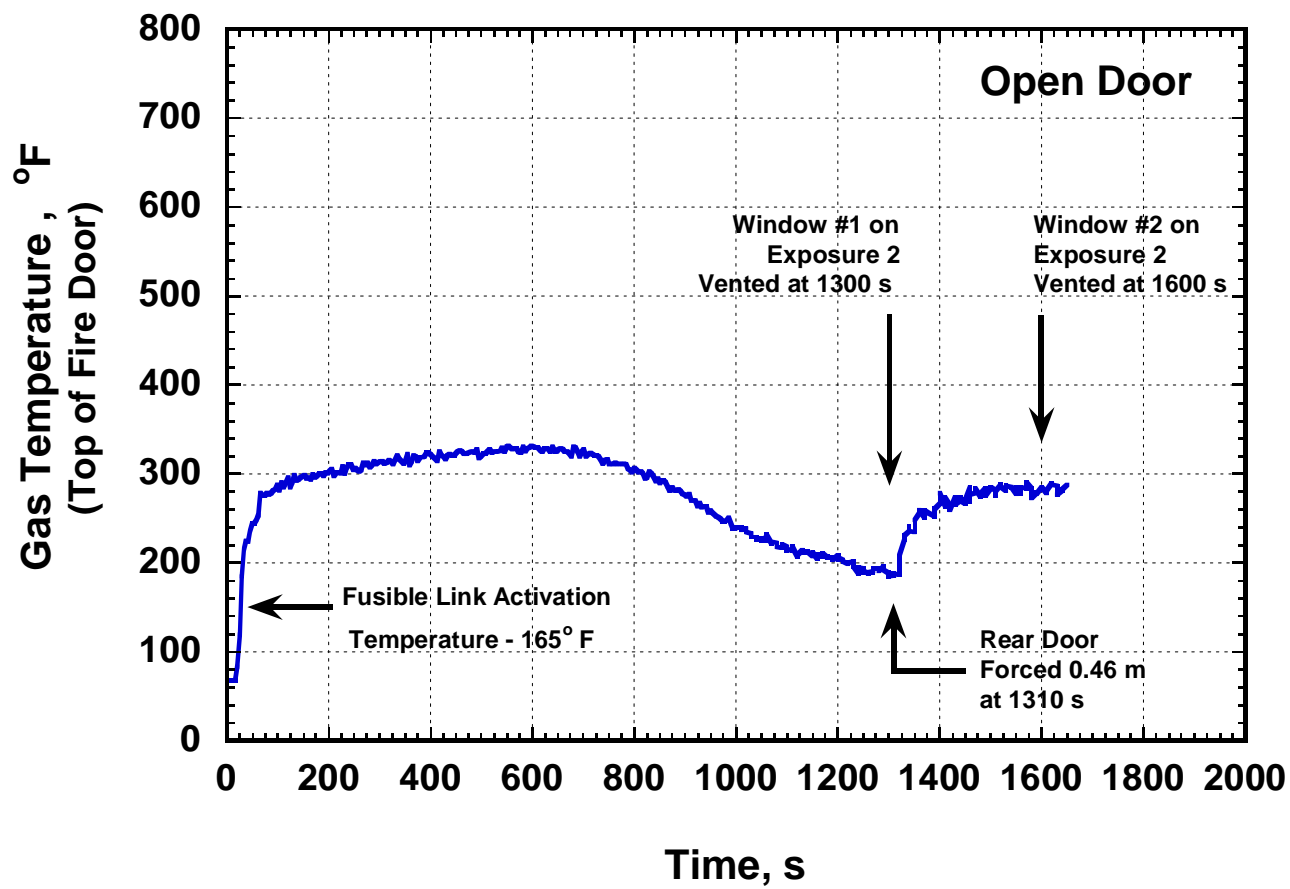

Figure 94. Temperatures (Fahrenheit) versus Time for Combustion Gases Near the Fusible Link on the Fire Door. For a Fire with an initial 500 kW Heat Release Rate, the Fire Door Closing Mechanism Was Disabled. 


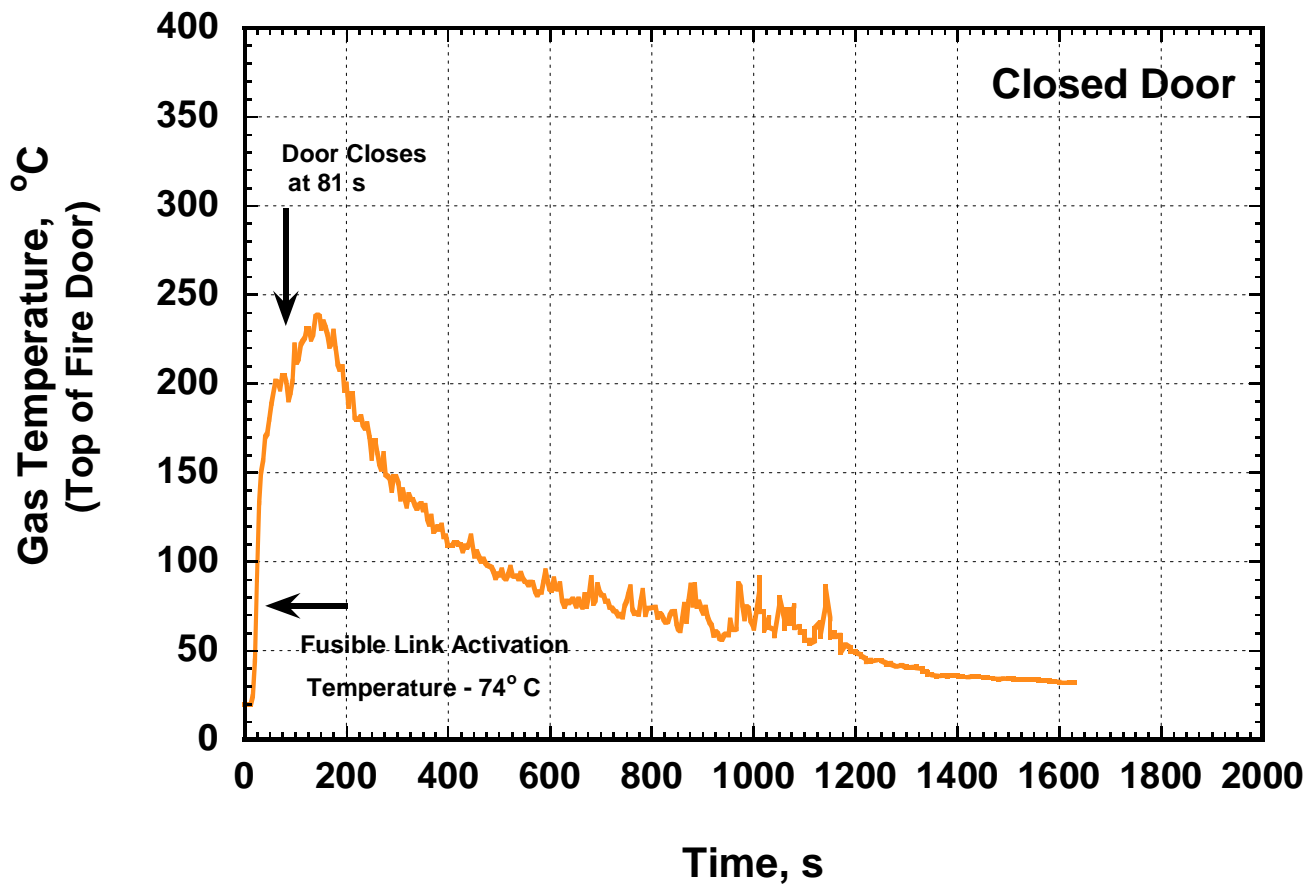

Figure 95. Temperatures (Centigrade) versus Time for Combustion Gases Near the Fusible Link on the Fire Door. For a Fire with an initial $1000 \mathrm{~kW}$ Heat Release Rate, the Fire Door Closed at 81 s.

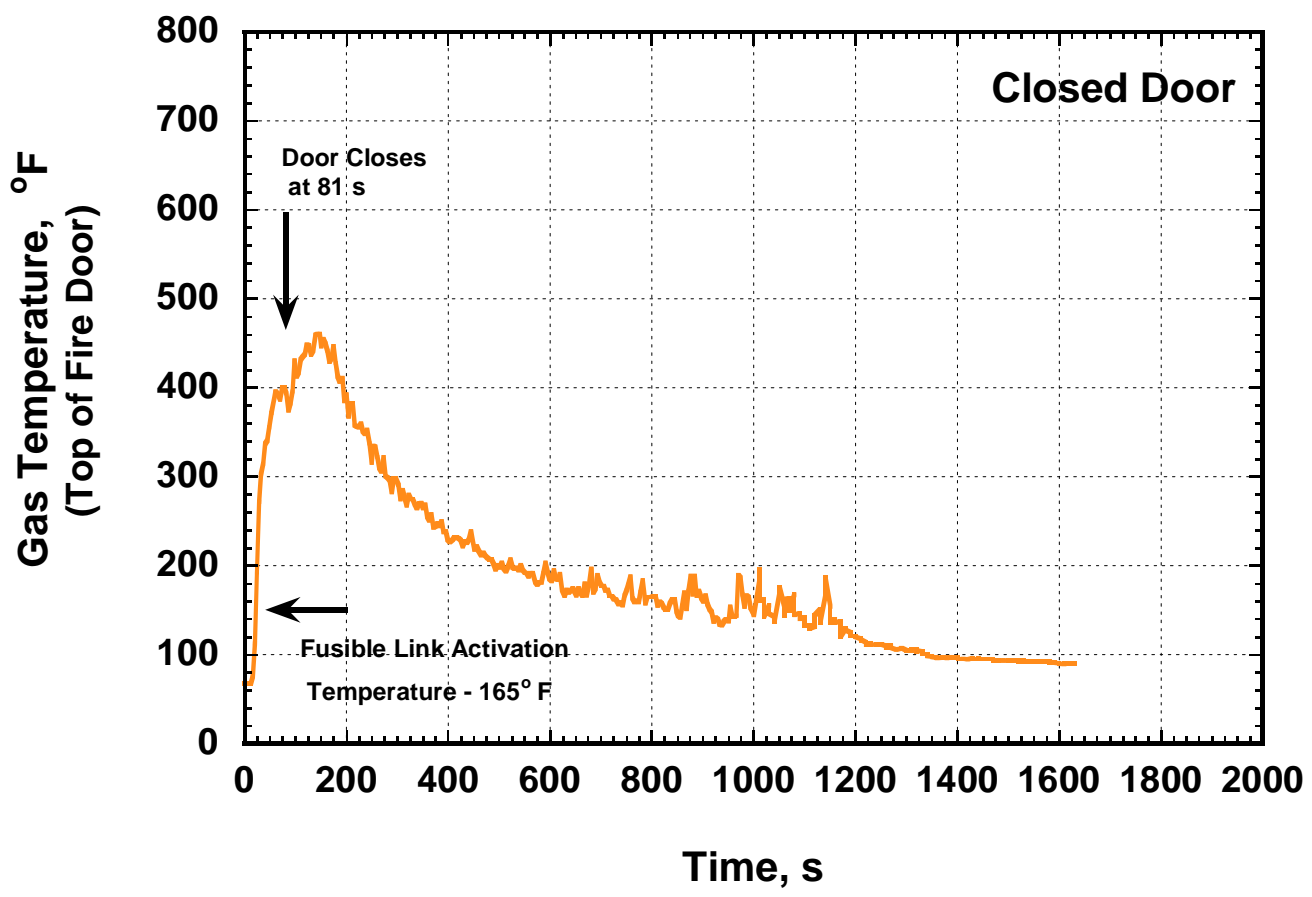

Figure 96. Temperatures (Fahrenheit) versus Time for Combustion Gases Near the Fusible Link on the Fire Door. For a Fire with an Initial $1000 \mathrm{~kW}$ Heat Release Rate, the Fire Door Closed at $81 \mathrm{~s}$. 


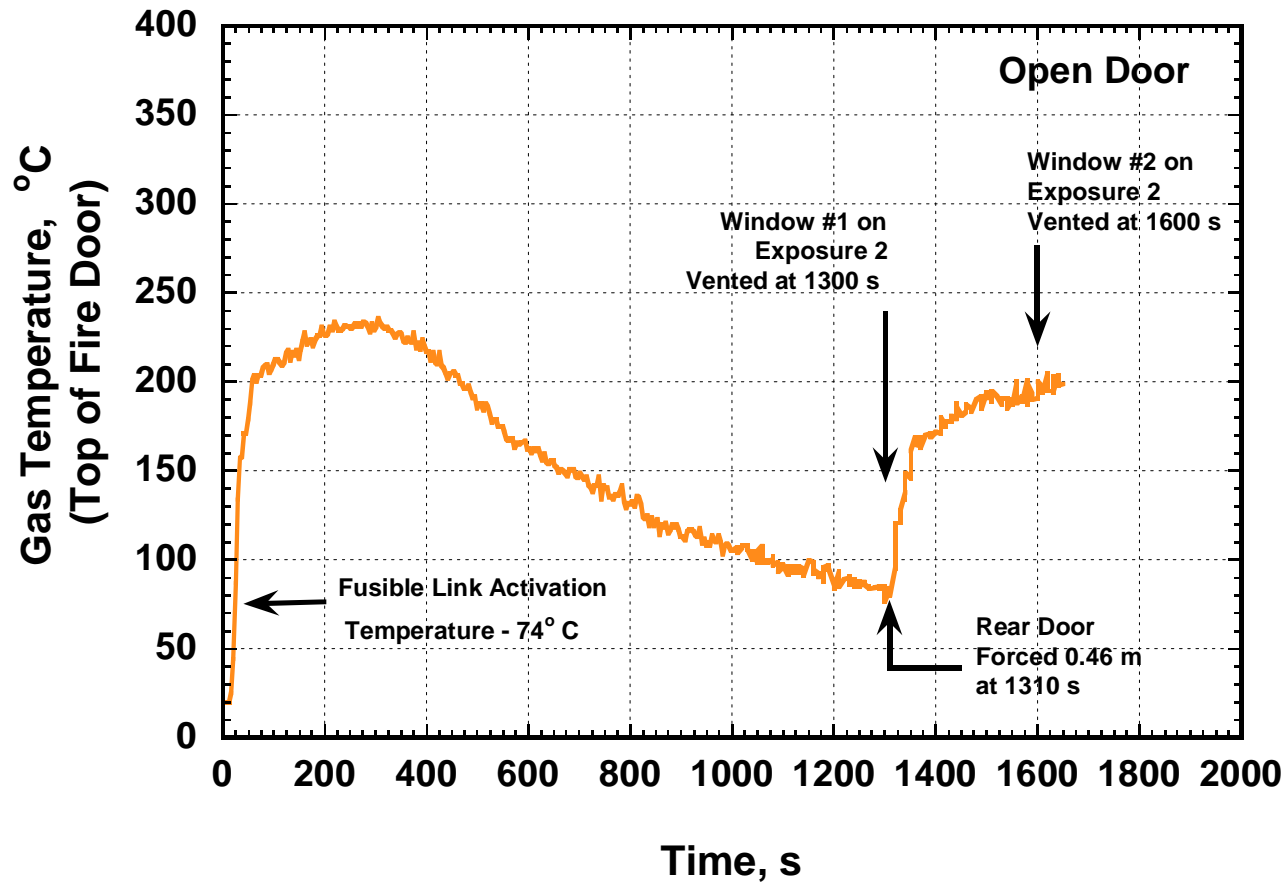

Figure 97. Temperatures (Centigrade) versus Time for Combustion Gases Near the Fusible Link on the Fire Door. For a Fire with an Initial $1000 \mathrm{~kW}$ Heat

Release Rate, the Fire Door Closing Mechanism Was Disabled.

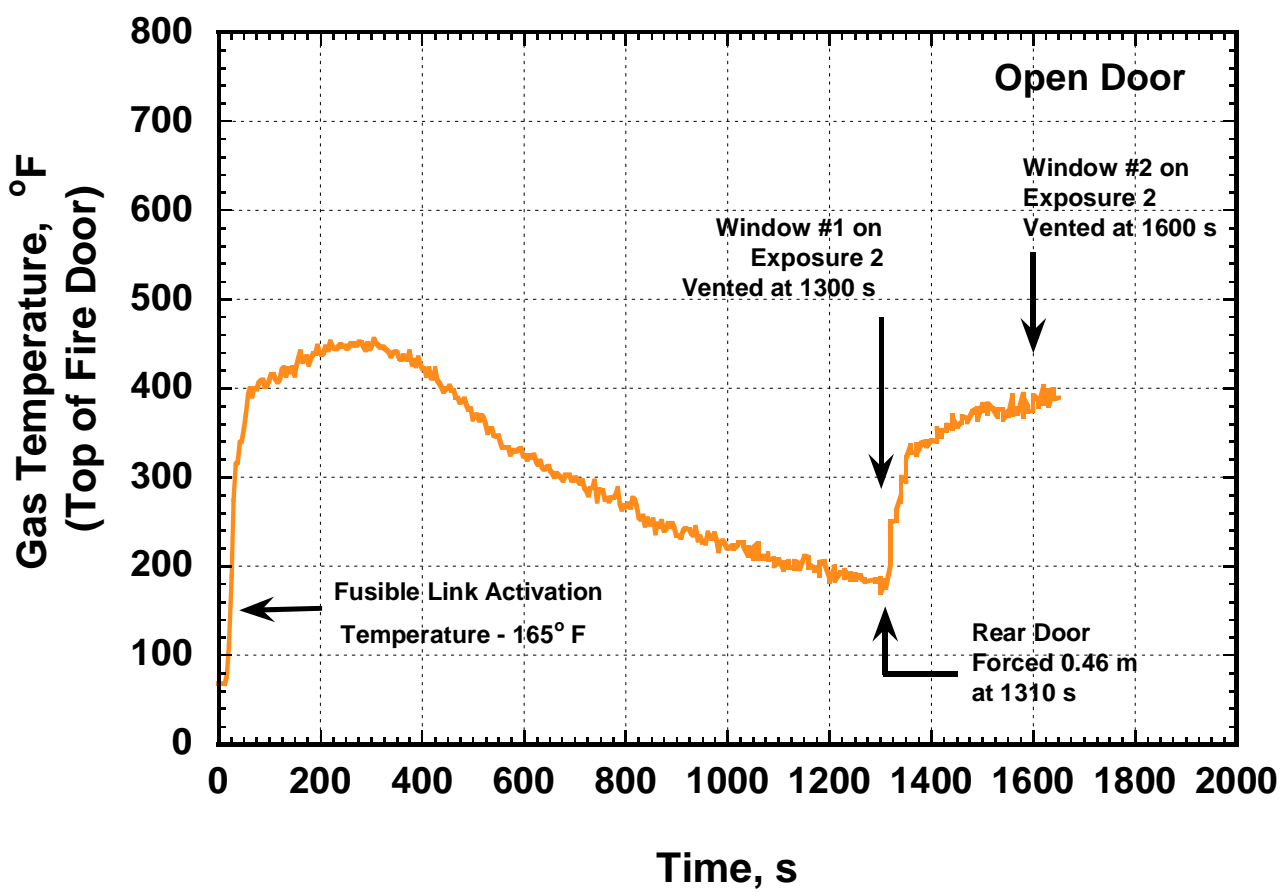

Figure 98. Temperatures (Fahrenheit) versus Time for Combustion Gases Near the Fusible Link on the Fire Door. For a Fire with an Initial $1000 \mathrm{~kW}$ Heat Release Rate, the Fire Door Closing Mechanism Was Disabled. 


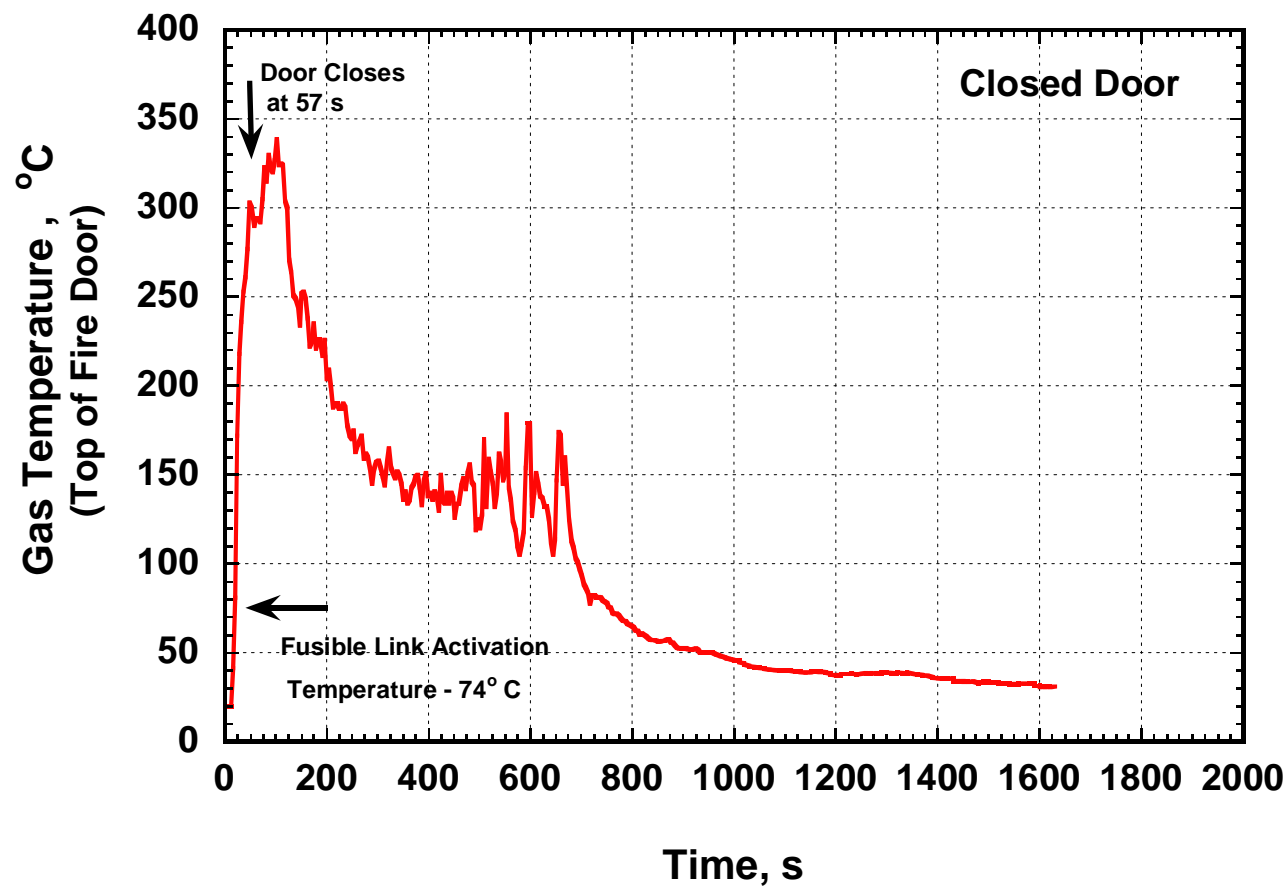

Figure 99. Temperatures (Centigrade) versus Time for Combustion Gases Near the Fusible Link on the Fire Door. For a Fire with an Initial 2000 kW Heat Release Rate, the Fire Door Closed at 57 s.

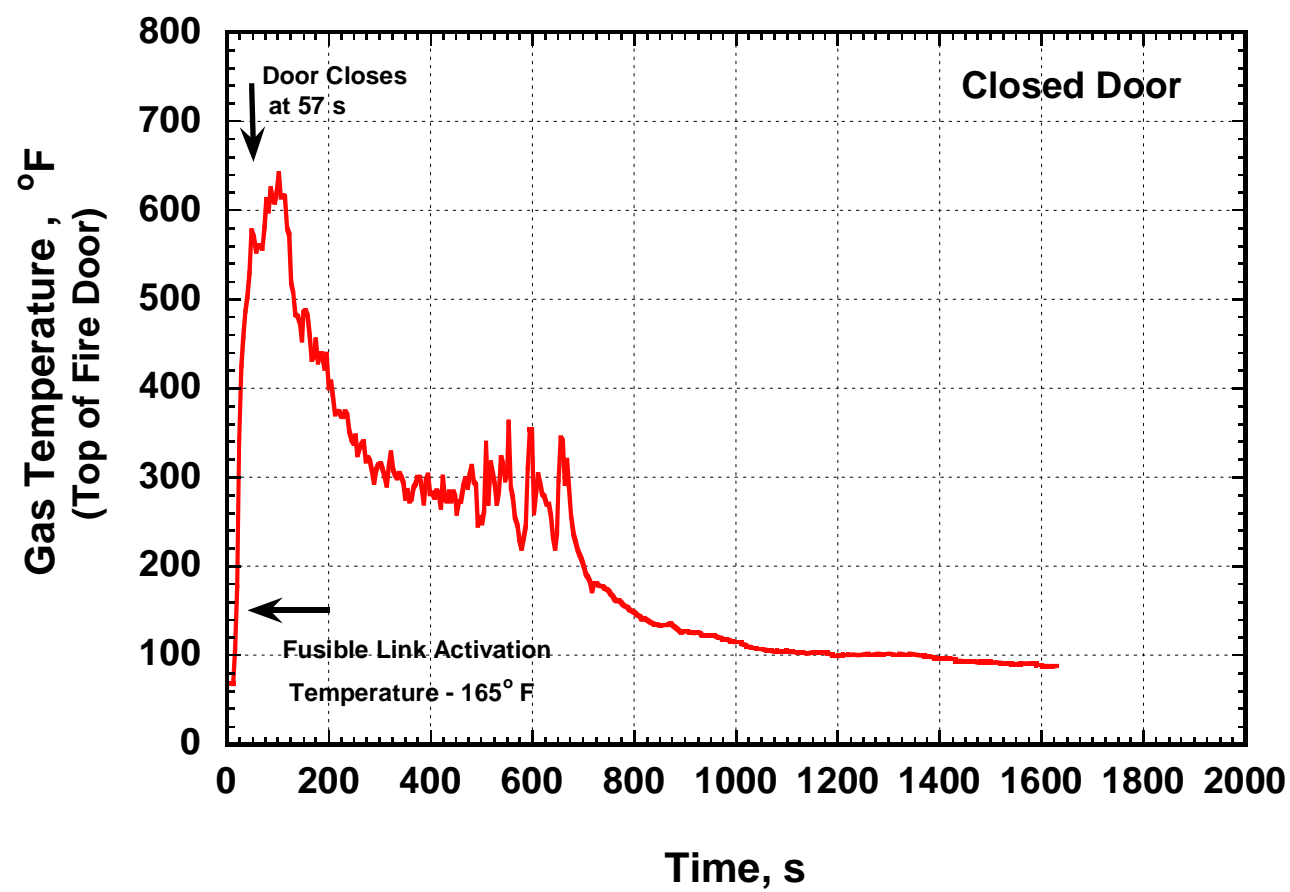

Figure 100. Temperatures (Fahrenheit) versus Time for Combustion Gases Near the Fusible Link on the Fire Door. For a Fire with an Initial 2000 kW Heat Release Rate, the Fire Door Closed at 57 s. 


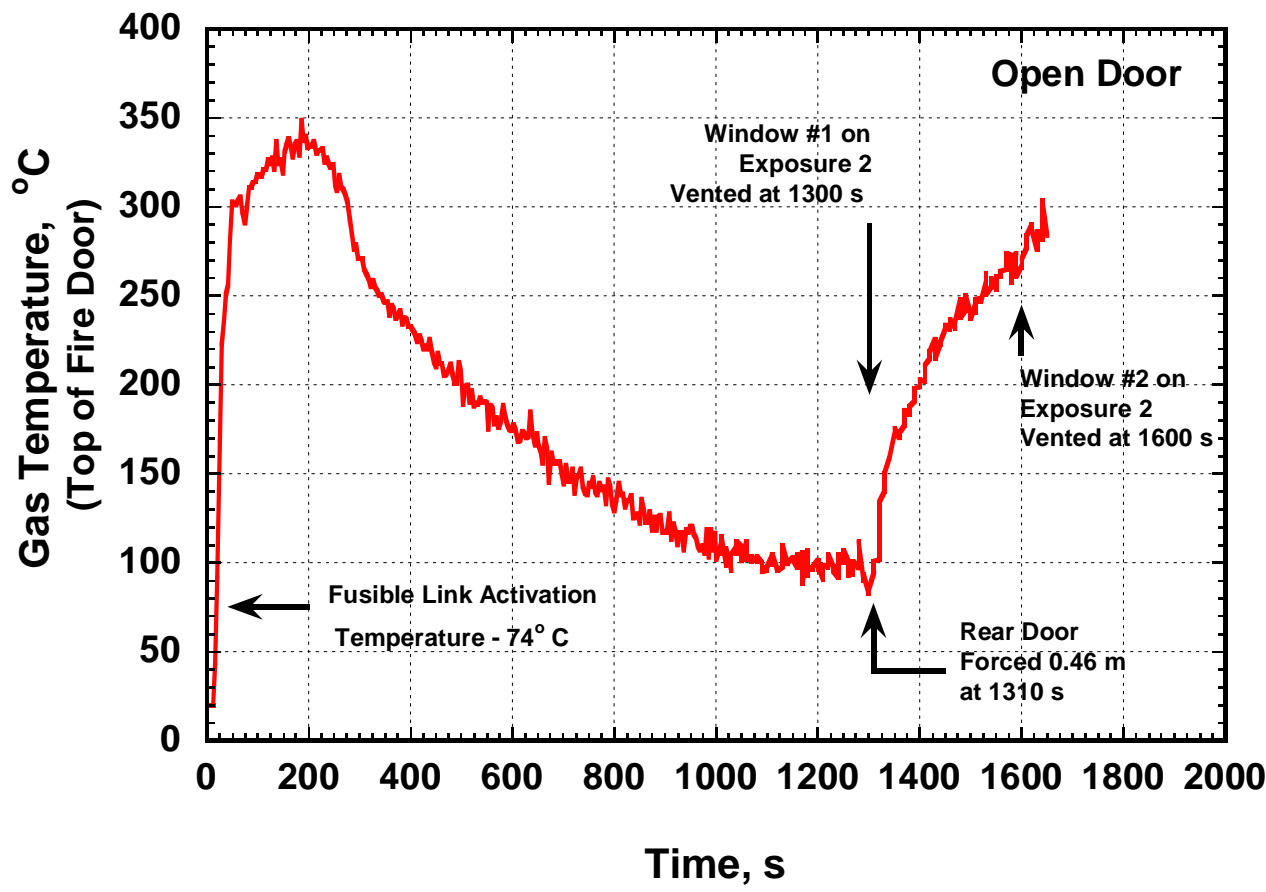

Figure 101. Temperatures (Centigrade) versus Time for Combustion Gases Near the Fusible Link on the Fire Door. For a Fire with an Initial $2000 \mathrm{~kW}$ Heat Release Rate, the Fire Door Closing Mechanism Was Disabled.

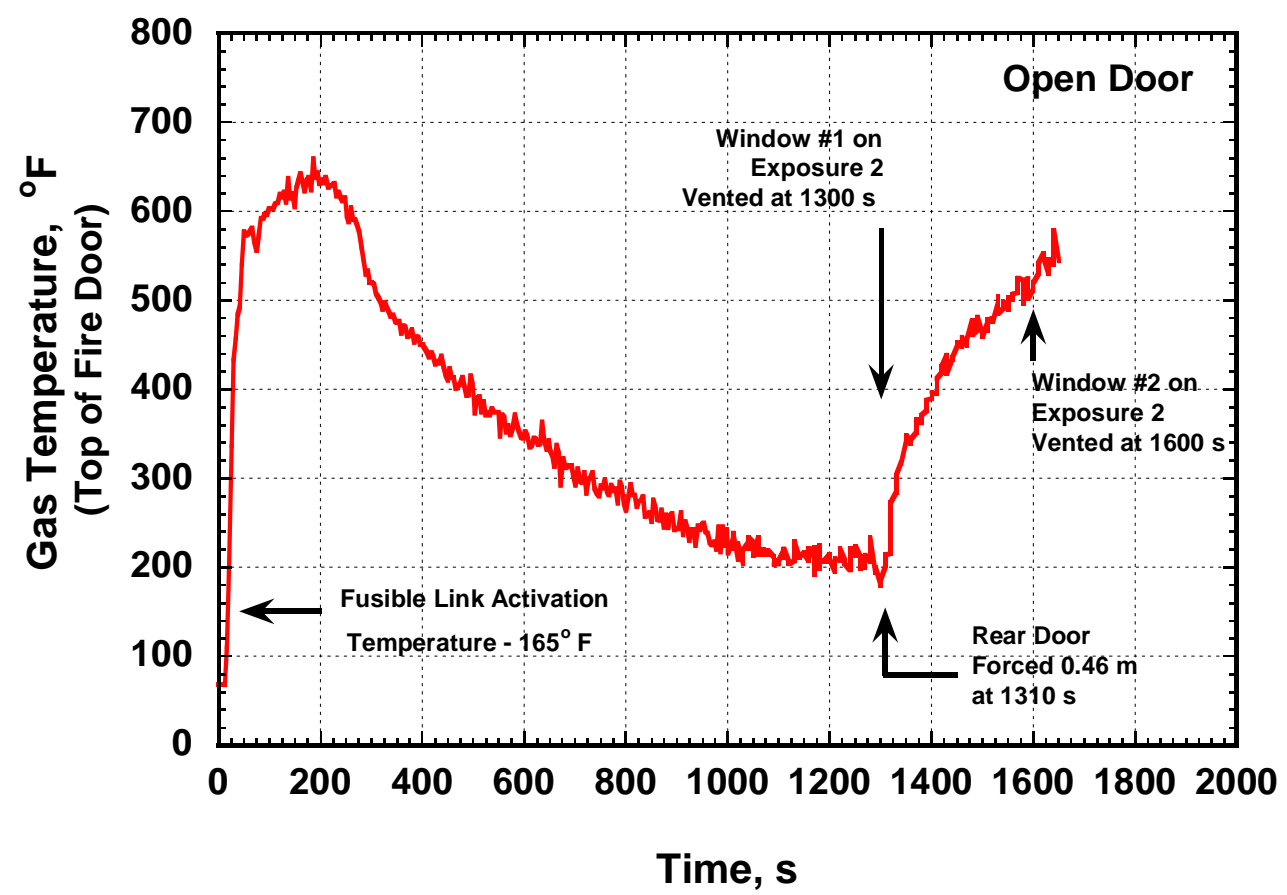

Figure 102. Temperatures (Fahrenheit) versus Time for Combustion Gases Near the Fusible Link on the Fire Door. For a Fire with an Initial $2000 \mathrm{~kW}$ Heat Release Rate, the Fire Door Closing Mechanism Was Disabled. 
In the closed door cases, the fires required 375 s, 204 s, and 130 s, to reduce the oxygen below $15 \%$ for the $500 \mathrm{~kW}, 1000 \mathrm{~kW}$, and $2000 \mathrm{~kW}$ heat release rates, respectively. In the open door cases where the fire had access to additional oxygen in Unit 22, the fires required $970 \mathrm{~s}, 550 \mathrm{~s}$, and $310 \mathrm{~s}$, to reduce the oxygen below $15 \%$ for the $500 \mathrm{~kW}, 1000$ $\mathrm{kW}$, and $2000 \mathrm{~kW}$ heat release rates, respectively.

While each of the fires depleted the available oxygen, the unburned fuel remained in the basement of Unit 20 and 22. If additional oxygen were introduced into the basement, mixed with the remaining fuel, and found an ignition source, the fire would rekindle and begin to grow as long as it had sufficient fuel and oxygen. In the closed door cases where the fire door would have prevented flow from Unit 20 into Unit 22, the additional air may have entered through the lower portion of the rear door. Smoke and hot gases would have exited through the upper portion of the same rear door. The closed fire door would have prevented the movement of smoke or fresh air between Unit 20 and 22. If the fire door had closed in the actual fire, the unburned fuels and evaporating solvents may have lead to a fuel rich environment where there were high concentrations of fuel, but insufficient oxygen to allow combustion in Unit 20. The closed fire door and single door at the rear of the basement would not have been conducive for allowing additional air to flow into the basement of Unit 20. Sudden venting of Unit 20 could have led to a flammable mixture developing in Unit 20 even though the fire door was closed. If this mixture would have supported combustion and the mixture found an ignition source, the fuel/air mixture could have ignited within Unit 20.

In the open door cases, the fire door remained open and air or smoke could flow through the fire door between Units 20 and 22. Similar to the closed door scenario, fresh air could have entered through the lower portion of the rear door and exited through the upper portion of the door. But, the basement windows which were opened on exposure \#2 would have also provided a path for the smoke to exit while the fresh air was being drawn in through the rear door. The model simulations for the open door cases indicate that fresh air would probably have been drawn in through the rear door while hot smoke and combustion products were exiting the basement windows on exposure \#2. In the actual fire, the unburned fuels and evaporating solvents may have lead to a fuel rich environment where there were high concentrations of fuel, but insufficient oxygen to allow combustion in Unit 20. However, as the air flowed in the rear door of Unit 20 and out the windows of Unit 22, the air would have probably entrained some of the unburned fuel and evaporated solvents as it passed through Unit 20. This mixture of fresh air and fuel would have flowed into the basement of Unit 22 which would have been less fuel rich since the solvents were in Unit 20. If the air/fuel flow into Unit 22 resulted in a flammable mixture that would have allowed combustion and the mixture found an ignition source, the fuel/air mixture could have ignited. 


\section{Summary}

This limited set of Fire Dynamics Simulator reconstructions of the Astoria fire provides insight into the gas temperature and oxygen concentrations that may have existed in the basement of Unit 20 and Unit 22. The closed door recreations indicate that the fusible link would probably have seen high enough temperatures to allow the fire door to close in less than $130 \mathrm{~s}$ for fire sizes between $500 \mathrm{~kW}$ and $2000 \mathrm{~kW}$. For comparison, these fire simulations also include scenarios where the fire door was not permitted to close. The closed door simulations demonstrate peak temperatures along the centerline of Unit 20 in excess of $480^{\circ} \mathrm{C}\left(896^{\circ} \mathrm{F}\right)$ for the $2000 \mathrm{~kW}$ fire. The open door reconstructions indicate peak temperatures along the centerline of Unit 20 in excess of $840^{\circ} \mathrm{C}\left(1544^{\circ} \mathrm{F}\right)$. The oxygen concentration profiles suggest that a $2000 \mathrm{~kW}$ fire with the fire door closed could have depleted the oxygen in Unit 20 in less than 380 s. A $2000 \mathrm{~kW}$ fire with the fire door open would have required more time, approximately $650 \mathrm{~s}$, in order to deplete the oxygen in Unit 20 and 22.

The reconstruction cases used a range of $500 \mathrm{~kW}, 1000 \mathrm{~kW}$, and $2000 \mathrm{~kW}$ fires to explore the impact of different fire sizes. These simulations assume a specific fire size and do not consider the origin or cause of the fire. These simulations focused on the fire growth after ignition and up to the explosion, but did not include the explosion itself. If only $4 \%$ of the organic solvents that appear to have been stored in the basement became involved in the fire, then the heat release rate would have exceeded $500 \mathrm{~kW}$. If $18 \%$ of the hydrocarbon fuels had been consumed by the fire, the heat release rate is estimated to exceed $2000 \mathrm{~kW}$. This range of heat release rates, from $500 \mathrm{~kW}$ to $2000 \mathrm{~kW}$, does not include any of the other merchandise or combustibles that were located in the basement.

\section{Acknowledgements}

The authors would like to thank the Fire Department of New York and the Bureau of Alcohol Tobacco and Firearms (ATF) for their documentation of the structure involved in this fire incident. The authors would like to specifically extend their appreciation to Mr. Robert Byrnes of FDNY Special Operations Command and Mr. Gerald Haynes of ATF Fire Laboratory for their assistance in this reconstruction. The authors would also like to thank Mr. Richard Braddee of NIOSH's Fire Fighter Fatality Investigation and Prevention Program for providing additional support for our fire reconstructions/line of duty death investigations. Finally we would like to thank Dr. Kevin McGrattan for his continued development of the NIST Fire Dynamics Simulator Model, and Dr. Glenn Forney for his continued development of SmokeView.

\section{References}

1. NIOSH Report "F2001-23 Hardware Store Explosion Claims the Lives of Three Career Fire Fighters- New York”, National Institute for Occupational Safety and Health, Cincinnati, OH, February 25, 2003, www.cdc.gov/niosh/firehome.html . 
2. $\quad$ Madrzykowski, D.; Vettori, R. L.; "Simulation of the Dynamics of the Fire at 3146 Cherry Road NE, Washington, DC, May 30, 1999”, National Institute of Standards and Technology, Gaithersburg, MD, NISTIR 6510, April 2000.

3 . Madrzykowski, D.; Forney, G. P.; Walton, W. D.; "Simulation of the Dynamics of a Fire is a Two-Story Duplex, Iowa, December 22, 1999”, National Institute of Standards and Technology, Gaithersburg, MD NISTIR 6854, January 2002.

4. $\quad$ Vettori, R.L.; Madrzykowski, D.; Walton, W.D.; "Simulation of the Dynamics of a Fire in a One-Story Restaurant - Texas, February 14, 2000”, National Institute of Standards and Technology, Gaithersburg, MD NISTIR 6923, October 2002.

5. McGrattan, Kevin B.; Baum, Howard R.; Rehm, Ronald G.; Hamins, Anthony; Forney, Glenn P.; "Fire Dynamics Simulator - Technical Reference Guide”, National Institute of Standards and Technology, Gaithersburg, MD, NISTIR 6467, January 2000.

6. McGrattan, Kevin B.; Hamins, Anthony; and Stroup, David; "Sprinkler, Smoke \& Heat Vent, Draft Curtain Interaction - Large Scale Experiments and Model Development”, National Institute of Standards and Technology, Gaithersburg, MD, NISTIR 6196-1, September 1998.

7. McGrattan, Kevin B.; Baum, Howard R.; Rehm, Ronald G.; "Large Eddy Simulations of Smoke Movement”, Fire Safety Journal, vol 30 (1998), p 161-178.

8. McGrattan, Kevin B.; Forney, Glenn P.; "Fire Dynamics Simulator - User’s Manual”, National Institute of Standards and Technology, Gaithersburg, MD, NISTIR 6469, January 2000.

9. Bunker, Merton, W.; Moore, Wayne, D.; "National Fire Alarm Code Handbook”, Third Edition, National Fire Protection Association, Quincy, MA, (1999), p 113-340.

10. McGrattan, Kevin B.; Hamins, Anthony; Stroup, David; “Sprinkler, Smoke \& Heat Vent, Draft Curtain Interaction-Large Scale Experiments and Model Development”, National Institute of Standards and Technology, Gaithersburg, MD, NISTIR 6196-1, September 1998. 
